
AND THEIR INFLUENCE ON PRECIPITATION

Ph.D. THESIS

Hakkı BALTACI

Department of Climate and Marine Sciences

Earth System Science Programme 



\title{
ATMOSPHERIC CIRCULATION TYPES IN MARMARA REGION (NW TURKEY) AND THEIR INFLUENCE ON PRECIPITATION
}

\author{
Ph.D. THESIS
}

Hakkı BALTACI

(601102003)

Department of Climate and Marine Sciences

Earth System Science Programme

Thesis Advisor: Prof. Dr. Tayfun KINDAP

DECEMBER 2015 

İklim ve Deniz Bilimleri Anabilim Dalı

Yer Sistem Bilimi Programı

Tez Danışmanı: Prof. Dr. Tayfun KINDAP 

Hakkı Baltac1, a Ph.D. student of ITU Eurasia Institute of Earth Sciences student ID 601102003, succesfully defended the dissertation entitled "Atmospheric circulation types in Marmara Region (NW Turkey) and their influence on precipitation", which he prepared after fulfilling the requirements specified in the associated legislations, before the jury whose signatures are below.

Thesis Advisor : $\quad$ Prof. Dr. Tayfun KINDAP Istanbul Technical University

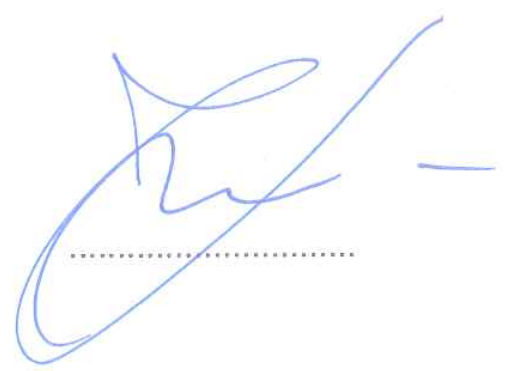

Jury Members : $\quad$ Prof. Dr. Mehmet KARACA Istanbul Technical University

Prof. Dr. Alper ÜNAL

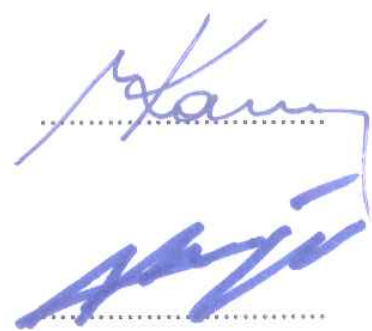

Istanbul Technical University

Prof. Dr. Mete TAYANÇ Marmara University

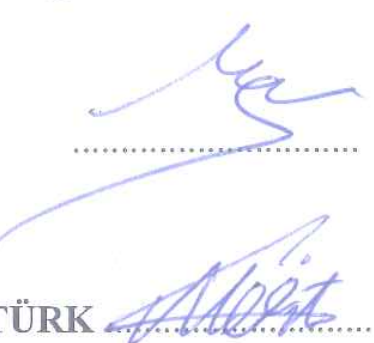

Asst. Prof. Dr. Ozan M. GÖKTÜRK Ondokuz Mayıs University

Date of Submission : 20 October 2015

Date of Defense ： 04 December 2015 
I dedicate this thesis to my family, 


\section{FOREWORD}

This study was conducted at Istanbul Technical University, Eurasia Institute of Earth Sciences over a period of time of four years from 2011 to 2015. The research presented and reported in this thesis contains not only comprehensive scientific results but also imprints of labor, perseverance and passion for science. This thesis owes thanks to many people for making the time working on my Ph.D. not an excruciating experience.

First of all, I owe great thanks to my supervisor Prof. Tayfun KINDAP for his inspiring guidance that has benefited me greatly with my growth into a mature and capable young scientist. I would like to thank Prof. Mehmet Karaca, Prof. Alper Ünal and Prof. Mete Tayanç for their academic support and constant encouragement in this work. I would like to thank all the committee members for their recommendations. I also would like to thank to all my professors that i have attended their lectures during my bachelor, masters and $\mathrm{PhD}$ studies at ITU.

It was a big chance to meet Assist. Prof. Ozan Mert Göktürk. Many thanks to him for being patient to me and sharing his experience, time and knowledge.

I'm grateful to my family, especially to my parents Necatdin and Suna BALTACI for their everlasting support and understanding, and my sisters and my brother for their support and joy.

Finally, I would like to thank my wife, Feyza Baltac1, who encouraged and supported me to finish this journey.

I hope my daughters Dilara and Sedef will do better than her parents in life and I wish they will have a good, successful life. 


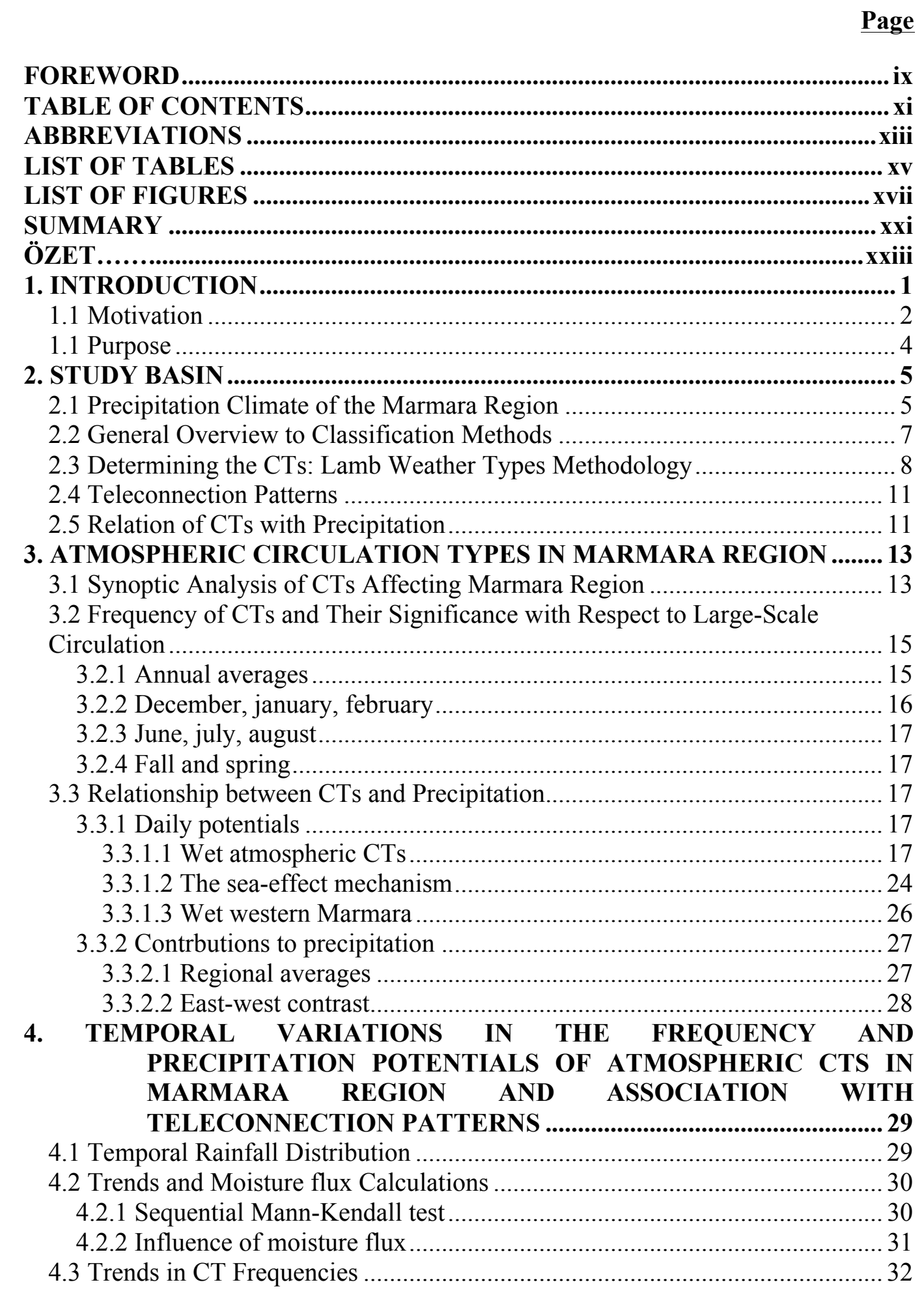


4.4 Trends in Precipitation Potentials of CTs

4.5 Temporal Behaviour of Winter (DJF) Rainfall during NE Cases: Moisture Flux

Transport Mechanism

4.6 Association with Teleconnection Patterns.................................................. 39

5. THE INFLUENCE OF ATMOSPHERIC CTS ON REGIONAL PATTERNS

OF PRECIPITATION IN MARMARA............................................ 43

5.1 Regional Patterns of Precipitation in Marmara ................................................. 43

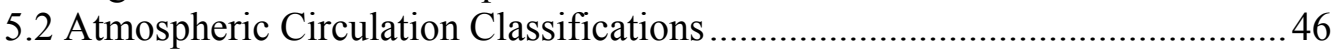

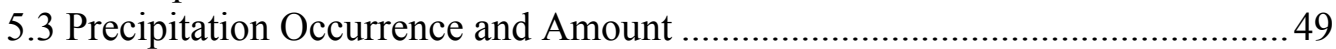

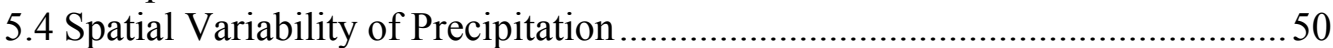

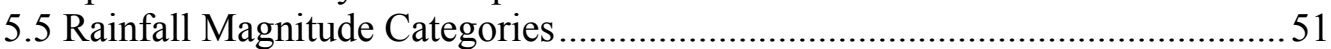

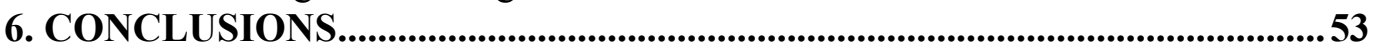

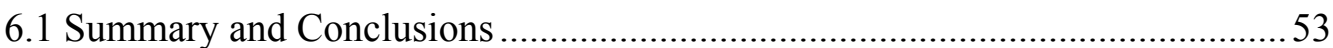

6.1.1 Atmospheric CTs and their influence on precipitation ............................53

6.1.2 Temporal behaviour of atmospheric CTs and their association with TPs. 54

6.1.3 Influence of CTs on regional patterns of precipitation .............................55

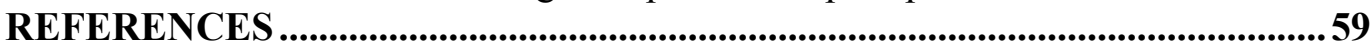

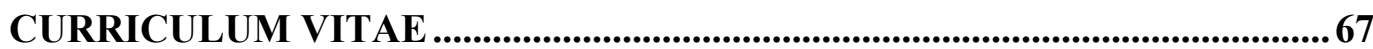




\section{ABBREVIATIONS}

$\begin{array}{ll}\text { AO } & \text { : Arctic Oscillation } \\ \text { CTs } & \text { : Circulation Types } \\ \text { EAWR } & \text { : East Atlantic West Russia Pattern } \\ \text { IPCC } & \text { : Intergovernmental Panel on Climate Change } \\ \text { LWT } & \text { : Lamb Weather Type } \\ \text { MAP } & \text { : Mean Annual Precipitation } \\ \text { NAO } & \text { : North Atlantic Oscillation } \\ \text { NCAR } & \text { : National Center for Atmospheric Research } \\ \text { NCEP } & \text { : National Center for Environmental Prediction } \\ \text { NOAA } & \text { : National Oceanic and Atmospheric Administration } \\ \text { RegCM3 } & \text { : Regional Climate Model Version 3 } \\ \text { SCA } & \text { : ScandinavianPattern } \\ \text { SST } & \text { : Sea Surface Temperature } \\ \text { TPs } & \text { : Teleconnection Patterns } \\ \text { TSMS } & \text { : Turkish State Meteorology Service }\end{array}$




\section{LIST OF TABLES}

Page

Table 2.1: Geographic coordinates, altitudes, and the DJF precipitation characteristics of the stations for the period from 1960 to 2012 ................ 6

Table 3.1 : Average specific humidity $\left(\mathrm{g} \mathrm{kg}^{-1}\right)$ at pressure levels $(\mathrm{mb})$ during type NW (1971-2010) at the NW of Marmara Region. ....................................... 23

Table 4.1 : Application of Mann-Kendall statistics to seasonal CTs occuring Marmara Region for the period 1971-2012 (95\% statistically significant numbers are marked bold).................................................................................. 32

Table 4.2 : Application of Mann-Kendall statistics to the seasonal daily precipitation (mm day-1). (95\% statistically significant numbers are marked bold)...36

Table 4.3 : Categories of daily precipitation (PRCP) for winter....................................37

Table 4.4 : Correlations between TPs and the frequency of CTs for each season. (99\% statistically numbers are marked bold)............................................40

Table 5.1 : The five-cluster solution of Ward's method between cluster algorithm. 45

Table 5.2 : Winter (DJF) mean frequencies of CTs and their contribution to the daily mean precipitation amounts ( $\mathrm{mm}$ day-1) and to total precipitation (\%) for the defined five clusters during the period 1960-2012................................. 46 


\section{LIST OF FIGURES}

Page

Figure 1.1 : (a) Spatial locations of the main teleconnection patterns (TPs). The figures represent the correlation between winter (DJF) $500 \mathrm{hPa}$ monthly standardized height anomalies and winter TPs index values from 1971 to 2012. (b) The 16 MSLP grid points used for classification of CTs. The dashed rectangles show Marmara Region (blue) over the NW part of the Anatolian Peninsula and the areal extent of SST (red). ................................ 3

Figure 2.1 : Winter (DJF) precipitation anomalies of Marmara for the period from 1960 to 2012. Dashed lines indicate the 10-year moving average............. 7

Figure 2.2 : (a) The 16 MSLP grid points used in the Lamb Weather Type analysis. Of the smaller (dashed) rectangles, the lower one covers the Marmara Region; whereas the upper right and upper left show the areal extent of sea surface temperature and specific humidity data respectively. (b) Marmara Region and its topography, along with locations, names and mean annual precipitation values of the meteorological stations used in the analysis. The size of each dot is proportionate with the mean annual precipitation.

Figure 3.1 : Long-term mean of normalized MSLP anomalies of each of the eight main directional and two vorticity CTs that affected Marmara Region during the period 1971-2010. $\mathrm{H}$ and $\mathrm{L}$ mark the high and low pressure centers

Figure 3.2 : Subjective re-categorization of the circulation types resulting from Lamb Weather Type analysis.

Figure 3.3 : Mean frequencies (in \%) of the ten main CTs during the period of 19712010. Hybrid types were merged into pure directional and vorticity types as described in the text.

Figure 3.4 : Long term (1971-2010) mean of daily precipitation for each circulation type for the whole year. Size of the dots vary according to the precipitation rate. The top-right 'average' values are the spatial averages.

Figure 3.5 : For DJF (winter), long term (1971-2010) mean of daily precipitation for each circulation type. Font colour of each CT is consistent with the categorization in Figure 3.2. Colour and size of the dots vary according to the precipitation rate. The top-right 'average' values are the spatial averages. 19

Figure 3.6 : For MAM (spring), long term (1971-2010) mean of daily precipitation for each circulation type. Font colour of each CT is consistent with the categorization in Figure 3.2. Colour and size of the dots vary according to the precipitation rate. The top-right 'average' values are the spatial averages.................................................................................................................... 21 
Figure 3.7 : For JJA (summer), long term (1971-2010) mean of daily precipitation for each circulation type. Font colour of each CT is consistent with the categorization in Figure 3.2. Colour and size of the dots vary according to the precipitation rate. The top-right 'average' values are the spatial averages. .22

Figure 3.8 : For SON (fall), long term (1971-2010) mean of daily precipitation for each circulation type. Font colour of each $\mathrm{CT}$ is consistent with the categorization in Figure 3.2. Colour and size of the dots vary according to the precipitation rate. The top-right 'average' values are the spatial averages.

Figure 3.9 : Long-term (1982-2010) monthly means of differences between SSTs and the $850 \mathrm{hPa}$ temperature over the Black Sea (see Figure 2.2 for the areal extent) during selected CTs. Standard deviations are shown only for $\mathrm{NE}$, to avoid confusion

Figure 3.10 : Pearson's correlation coefficients (r) between monthly average SST$850 \mathrm{hPa}$ temperature difference over the Black Sea during type NE and (a) monthly ratio of wet NE days to all NE days, (b) monthly average of daily precipitation amount during NE days. Correlations greater than 0.14 are statistically significant at the 0.99 confidence level according to Student's t-test. The period is 1982-2010. See Figure 2.2. for the areal extent of SST and $850 \mathrm{hPa}$ temperature.

Figure 3.11 : Long-term (1971-2010) mean contributions (as percentage to each seasonal total) of each of the ten main CTs to the regionally averaged precipitation.

.27

Figure 3.12 : Long-term (1971-2010) mean contribution (as percentage to each seasonal total) of each of the ten main CTs to the precipitation at stations (a) Kirklareli (western station) and (b) Sakarya (eastern station) ............27

Figure 4.1 : Temporal annual (black) and winter (dashed) precipitation variability in Marmara based on the weighted averages of the 22 stations. Vertical lines indicate the standard deviation of the precipitation for each year...30

Figure 4.2 : Temporal evolution of selected CTs according to the $95 \%$ significance level (Table 4.1) during all seasons for the period 1971-2012. The dashed lines denote the 10 -year moving average .....................................................34

Figure 4.3 : Temporal distribution of regional daily rainfall $(\mathrm{mm} /$ day $)$ in active winter-NE times for the period 1971-2012. .37

Figure 4.4 : Composite maps of synoptic conditions, moisture flux and $850 \mathrm{hPa}$ winds $(\mathrm{m} / \mathrm{s})$ based on the light (a) and intense daily rainfall magnitudes (b) during winter-NE times. Colour values indicate the integrated meridional moisture flux $\left(\mathrm{kgm}^{-1} \mathrm{~s}^{-1}\right)$. .38

Figure 4.5 : Correlation between different teleconnection patterns (NAO (square)), EA (triangle), EA/WR (plus), SCA (star) and AO is shown as circles) and the frequency of atmospheric circulation patterns for the different seasons. Solid and dashed lines express $99 \%$ and $95 \%$ statistically significance level, respectively. 41

Figure 5.1 : The five clusters of the Marmara Region according to Ward's method. The cluster letters are explained in Table 5.1 ............................................44

Figure 5.2 : Box-plot of the Ward's method clusters for the 1960-2012 period. The cluster letters are explained in Table 5.1 46 
Figure 5.3 : Long term wintertime daily mean sea level pressure (MSLP) composites of each of the eight main directional and two vorticity CTs during the period from 1960 to 2012. The red rectangle indicates the Marmara Region. $\mathrm{H}$ and $\mathrm{L}$ mark the high and low pressure centres, respectively . 48

Figure 5.4: The probability of having a wet day for the directional and two vorticity CTs for the five sub-basins (cluster letters A, B, C, D, and E).

Figure $5.5:$ a) The normalized relative occurrence of rainy days per CT $\left(\mathrm{PROB}_{\mathrm{ct}} / \mathrm{PROB}_{\mathrm{tot}}\right)$ and $\left.\mathrm{b}\right)$ the normalized relative daily intensity of precipitation per CT $\left(\mathrm{PREC}_{\mathrm{ct}} / \mathrm{PREC}_{\mathrm{tot}}\right)$ for each cluster and CT. Circle, square, triangle, plus, and multiplication signs mark the sub-regional precipitation marked by cluster letters $\mathrm{A}, \mathrm{B}, \mathrm{C}, \mathrm{D}$, and E, respectively. $\mathbf{5 1}$

Figure 5.6 : Percentage contribution of a) $\mathrm{N}$ and b) $\mathrm{C}$ synoptic weather types to the winter categories of precipitation for five clusters. 


\section{ATMOSPHERIC CIRCULATION TYPES IN MARMARA REGION (NW TURKEY) AND THEIR INFLUENCE ON PRECIPITATION}

\section{SUMMARY}

The Marmara Region comprises the northwestern end of Anatolia and the southeastern end of the Balkans: two peninsulas separated by Dardaneles and Bosphorus straits, and the Sea of Marmara. Located on two continents, Asia and Europe, this unique area is the most industrialized, agriculturally developed and populated geographical division in Turkey with a population density of up to 2500 people per $\mathrm{km} 2$ in Istanbul, averaging 300 people per km2 regionally. Parallel to its economic development, the region continues to draw migration from other regions in Turkey. This leads to an ever increasing demand for water, while threatening the existing water resources in the form of new and uncontrolled building activity over water reservoirs. Thus, amount and variability of precipitation play a key role in the management of limited water supply.

Large-scale circulation patterns and synoptic patterns play significant role in determining the precipitation climate of the region. For the first time, in order to reveal the synoptic properties of the Marmara, circulation types, their long-term mean occurrence frequencies and relationships with precipitation are investigated. Automated Lamb Weather Types classification method is applied on NCEP/NCAR daily mean sea level pressure data to determine circulation types. Northeasterly (NE) and easterly (E) types are found to be the most frequent both on the annual basis and during winter (DJF, the wettest season in the region). Circulation types with the highest rainfall potential, namely the cyclonic $(\mathrm{C})$ and northerly $(\mathrm{N})$, are among the least frequent; therefore they are not the dominant "rainfall modes". Instead, NE and E have the greatest contribution to the regionally averaged rainfall amount, although they do not have the highest potential to create precipitation. This shows that Marmara Region receives a substantial amount of precipitation from northerly and easterly maritime trajectories, implying a profound influence of the Black Sea on the rainfall regime in this area. However, rainfall at the stations that are far away or less affected by the Black Sea (especially at the ones in the west) occurs during types with a southerly component (S, SW and SE).

In addition to the relationship between CTs and precipitation in Marmara, the significant roles of the teleconnection patterns (TPs) on CTs and precipitation mechanism were also investigated. For this purpose, five main TPs, namely North Atlantic Oscillation (NAO), Arctic Oscillation (AO), East Atlantic (EA), East Atlantic-West Russia (EAWR) and Scandinavian (SCA) patterns index values were used. EA/WR is the most influential pattern in the occurrence of CTs during winter, exhibiting positive significant (at 99\% level) correlations with $\mathrm{NE}$ and $\mathrm{NW}$; and negative ones with SW and C. the strongest association of EA/WR is with NE and $\mathrm{NW}$; and negative ones with SW and C. The second most influential teleconnection pattern on the CTs of Marmara Region during DJF is the AO, whose relationship 
with the occurrence of $\mathrm{NE}, \mathrm{SW}$ and $\mathrm{C}$ is in the same fashion with $\mathrm{EA} / \mathrm{WR}$. Surprisingly, the NAO, whose wintertime impact on Turkey is the most studied and documented among all teleconnection patterns; has generally weak and insignificant influence on the occurrence of CTs in Marmara Region in DJF.

In water management strategies, the amount of precipitation in particular basin has a great importance. Therefore, which CTs quantitatively cause precipitation occurrence and intensity in the sub-basins of the Marmara were investigated. By applying Ward's hierarchical cluster analysis, Marmara were divided into five coherent zones, namely Black Sea-Marmara, Black Sea, Marmara, Thrace and Aegean sub-regions. Precipitation occurrence suggested that wet CTs (i.e. N, NE, NW, and C) offer a high chance of precipitation in all sub-regions. For the eastern (western) part of the region, the high probability of rainfall occurrence is shown under the influence of $\mathrm{E}$ (SE, S, SW) atmospheric CTs. In terms of precipitation intensity, N and C CTs had the highest positive gradients in all sub-basins of the Marmara. In addition, although Marmara and Black Sea sub-regions have the highest daily rainfall potential during NE types, high daily rainfall totals are recorded in all sub-regions except Black Sea during NW types. 


\section{MARMARA BÖLGESİNDEKİ ATMOSFERİK SİRKÜLASYON PATERNLERİ VE YAĞIŞ ÜZERINE ETKILLERI}

\section{ÖZET}

Marmara Bölgesi, Anadolu'nun kuzeybatı ucunda ve Balkanlar'ın güneydoğu kısmında yer alan; Marmara Denizi, Boğaziçi ve Gelibolu Boğazlarıyla ayrılan iki yarımadadan oluşmaktadır. Asya ve Avrupa kıtalarında konumlanan bu bölge, Türkiye'nin endüstriyel ve tarımsal anlamda en gelișmiș ve nüfusun en yoğun olduğu bölgesidir. Nüfus yoğunluğu bölgede $\mathrm{km}^{2}$ ' ye 300 kişi olup, bu rakam İstanbul'da 2500'e çıkmaktadır. Ekonomik gelișimine paralel olarak, bölge Türkiye'nin diğer kesimlerinden göç almaya devam etmektedir. Süregelen bu göç su talebini arttırmakla beraber, su havzasındaki kontrolsüz yapılașmaya sebep olarak mevcut su kaynaklarını da tehdit etmektedir. Böylece, yağış miktarı ve rejimi sınırlı olan su kaynaklarının yönetiminde önemli rol oynamaktadır.

Büyük ölçekteki atmosferik sirkülasyon patenleri ve sinoptik paternler bölgenin iklimini belirlemede önemli rol oynarlar. İlk olarak, Marmara Bölgesi'nin sinoptik özelliklerini belirlemek için, sirkülasyon tipleri ve onların uzun dönemli ortalama sıklıkları ile yağıș arasındaki ilișkiler incelendi. Sirkülasyon tiplerini belirlemek için, Otomatik Lamb Hava Tipleri sinıflandırma metodu NCEP/NCAR'in günlük ortalama deniz seviyesi basıncı bilgilerine uygulandı. Deniz seviyesi basınç anomali değerleri sonucunda, başlıca 10 sirkülasyon paterni subjektif olarak üç gruba ayrıldı. $\mathrm{Bu}$ gruplar; Kategori I (NE ve E), Kategori II (SW, S, SE) ve Kategori III (W, NW, N) olmakla beraber, bunların dışında kalan 2 paterni de siklonik (C) ve antisiklonik (A) hava tipleri oluşturmaktadır.

Kategori I hava tiplerinde, Doğu Avrupa üzerinde yüksek basınç anomalisi mevcuttur. Bunun sonucunda paternler Marmara Bölgesi üzerine kuzeydoğulu ve doğulu olarak gelmektedir. Bütün bir yıl boyunca Marmara Bölgesi üzerinde etkin olan hava tiplerini oluşturmaktadır. Kategori II' de ise İtalya üzerinde alçak basınç merkezi bulunmakta ve sıklıkla kış aylarında görülmektedir. Kategori III paternlerinde ise Karadeniz üzerinde alçak basınç merkezi bulunmakta, bunun neticesinde bölgemiz üzerine batılı, kuzeybatılı ve kuzeyli akıșlar gelmektedir. Siklonik hava tiplerinde Marmara üzerinde alçak basınç merkezi bulunurken, Antisiklonik sirkülasyonda ise yüksek basınç merkezi bulunmaktadır.

Yıllık bazda ve bölgede yılın en yağışlı mevsimi olan kışın (Aralık, Ocak ve Şubat), kuzeydoğulu ve doğulu hava tipleri bölgede en sık rastlanan hava tipleri oldular. En fazla yağış yapma potansiyeline sahip sirkülasyon tipleri başlıca siklonik ve kuzeyli tiplerdir, halbuki bu tipler en az sıklıkla rastlananlar arasında olduğundan bölgede egemen olan yağış mekanizması değildir. Bunların yerine, daha az yağış yapma potansiyeline sahip olan fakat daha sıklıkla görülen kuzeydoğu ve doğulu akışlar yağış miktarlarının büyük kısmını oluştururlar. Bu ilişki, Marmara Bölgesi'nin kuzeyinde bulunun Karadeniz'den gelen kuzeyli ve doğulu akışlardan önemli miktarda yağış aldığını gösterip, Karadeniz'in bölgenin yağış rejimindeki etkisini 
göstermektedir. Diğer yandan, Karadeniz'e coğrafi olarak uzakta bulunan veya kuzeydoğulu akışlardan daha az etkilenen istasyonlarda (özellikle bölgenin bati kesimindekilerde), yağışlar daha çok güneyli akışlarda meydana gelmektedir.

Marmara Bölgesi'ni etkileyen sirkülasyon tipleri ve vuku bulan yağış arasındaki ilişkiye ek olarak, uzak etkileşim paternlerin (teleconnection) sirkülasyon tipleri ve yağış mekanizmaları üzerindeki etkileri incelendi. Bu amaçla, beş başlıca uzak etkileşim indeks değerleri kullanıldı. Bunlar Kuzey Atlantik Salınımı, Arktik Salınım, Doğu Atlantik, Doğu Atlantik-Batı Rusya ve İskandinavya paternleri. Uzak etkileşimler arasında Doğu Atlantik-Batı Rusya uzak etkileşimi kış aylarındaki sirkülasyon tiplerini en fazla etkileyenidir. Bu etkileşim ile sırasıyla kuzeydoğulu ve kuzeybatılı sirkülasyon tipleri arasında pozitif, güneybatı ve siklonik sirkülasyon tipleri arasında negatif ilişkiler istatistiksel olarak anlamlı bulunmuştur. Bölgedeki sirkülasyon tiplerini kışın etkileyen ikinci uzak etkileşim örüntüsü Arktik Salınımdır. Arktik Salınım da Doğu Avrupa-Batı Rusya uzak etkileşimi gibi kuzeydoğu, güneybatı ve siklonik sirkülasyon tiplerini etkilemektedir. İlginçtir ki, uzak etkileşimler arasında Türkiye'ye kışın etkisi en fazla inceleneni olan Kuzey Atlantik Salınımı kışın Marmara Bölge'sindeki sirkülasyon tiplerinin sıklığına etkisi genellikle zayıf ve önemsizdir.

$\mathrm{Bu}$ sonuçlara ek olarak, kış mevsiminde özellikle kuzeydoğulu paternlerin (NE) sayısında önemli bir azalma görülmekle beraber, günlük yağış miktarlarında artış eğilimi göze çarpmaktadır. Bunun nedeni araştırıldığında, kuzeydoğulu hava tiplerinin hakim olduğu kış aylarında, günlük yağış miktarındaki artışın başlıca nedeni olarak, Doğu Avrupa'da bulunmakta olan yüksek basınç merkezine ek olarak, Kıbrıs üzerinde alçak basınç merkezi bulunmakta ve bu durum neticesinde fazla miktarda nem Karadeniz üzerinden bölgemize transfer edilmektedir. Ayrıca, Karadeniz üzerindeki deniz suyu sıcaklığınında ortalamadan $0.6{ }^{\circ} \mathrm{C}$ fazla olmas atmosferdeki nem içeriğini artırmaktadır.

Su kaynakları yönetiminde, belirli havzalardaki yağış miktarları büyük öneme haizdirler. Bu yüzden, sirkülasyon tiplerinin Marmara'nın alt bölgelerinde yağış oluşturma sıklığ 1 ve yağış şiddetleri sayısal olarak incelenmiştir. Bu incelemede, Ward'in hiyerarşik kümeleme tekniği 1960-2012 arası kış mevsimi 19 meteoroloji istasyonu günlük yağış miktarlarına uygulanarak; Marmara Bölgesi kendi içinde benzer özelikler gösteren bes alt bölgeye ayrılmıştır. Bu bölgeler: KaradenizMarmara alt bölgesi, Karadeniz alt bölgesi, Marmara alt bölgesi, Trakya alt bölgesi ve Ege alt bölgesi. Karadeniz-Marmara alt bölgesini Kireçburnu, Kumköy, Şile ve Çınarcık istasyonları oluşturmaktadır. Kocaeli ve Sakarya istasyonları ise Karadeniz özelliği göstermektedir. Daha çok Marmara iklimini oluşturan istasyonlar Bursa, Yalova, Keles, Bandırma ve Florya' dır. Edirne, Kırklareli, Lüleburgaz, Çorlu ve Tekirdağ daha çok Trakya bölgesi özelliği sergilerken, Çanakkale, İpsala ve Malkara istasyonları ise Ege alt bölgesini oluşturmaktadır.

Yağış sıklıkları incelendiğinde, yağışlı sirkülasyon tipleri (kuzey, kuzeydoğu, kuzeybatı ve siklonik) bütün alt bölgelerde daha fazla yağış yapma olasıllı̆ına sahiptir. Marmara'nın doğu kesimleri, doğulu atmosferik sirkülasyon tipinde daha fazla yağış sıklığı görülürken; batı kesimlerinde ise güneydoğu, güney ve güneybatılı sirkülasyon tipleri etkisindeyken daha fazla yağıș olması ihtimali görülmektedir. Kuzey ve siklonik sirkülasyon tipleri bölgenin tümünde diğer paternlerden daha şiddetli yağışlara sebep olmaktadır. Siklonik tiplerin \%37'sinde günlük yağış miktarının 9 mm' den fazla olduğu Trakya ve Ege alt bölgelerinde görülmüştür ve bu 
durum da bu alt bölgelerin sel ve su baskını olaylarına duyarlılığını göstermektedir. Buna ek olarak, Marmara ve Karadeniz alt bölgelerinde maksimum günlük yağış potansiyelleri kuzeydoğulu tiplerde gözlemlenirken, yüksek günlük yağış miktarları Karadeniz alt bölgesi haricinde diğer alt bölgelerde kuzeydoğulu tipte görüldü. 


\section{INTRODUCTION}

According to the Fifth Assessment Report (AR5) of the Intergovernmental Panel on Climate Change (IPCC, 2014), urbanization will rapidly increase in Eastern Europe countries depending on economic growth, population growth and land use planning. In parallel, it is predicted increasing demand to the fresh water for agriculture (Iglesias and Ouroga, 2007), vegetation dynamics (Gouveia et al., 2008) and energy production (Trigo et al., 2004). It is known that precipitation is the mainly source of the water basins and any significant temporal or spatial change of its influence the usage of fresh water. Therefore, one of the most significant issues in climate sciences is understanding the characteristics of rainfall and its spatio-temporal variability in a region because of its social and economic implications (Collier and Krzysztofowicz 2000 and references therein). For this purpose, while some studies are focusing on the large-scale circulations and synoptic patterns that bring more or less precipitation, some researchers afforded to determine the climate regions of the particular region or country.

In order to characterize the influences of synoptic weather patterns on the surface climate, circulation types (CTs) methods have proven useful for certain area (Huth et al., 2008; Dayan et al., 2012 and references therein). A database of CT classifications has been compiled by Philipp et al., (2010), who divide all available methods into two main categories according to the 'strategy' of classification. In the first category of methods, the strategy is to 'predefine' a set of CTs before the analysis, in order to classify each case within these types. Predefinition of CTs can be done either purely subjectively (e.g. Hess and Brezowsky, 1952; Lamb, 1972) or by declaring quasiobjective borderlines between types in the form of thresholds (e.g. Litynski, 1969; Jones et al., 1993; Dittmann et al., 1995). The second category of methods, which can be based on techniques such as principal components (e.g. Huth, 1993), leader algorithm (e.g. Blair, 1998) or optimization (e.g. Philipp et al., 2007), produce 'derived' CTs that are revealed (thus, 'defined') only after the mentioned analyses. Automated Lamb Weather Types (LWT) methodology (Jenkinson and Collison, 
1977; Jones et al., 1993) is of the first category. Using the 'predefinition' strategy, it classifies daily mean sea level pressure (MSLP) fields according to certain predefined thresholds in flow direction, flow strength and vorticity; hence determining the CTs. In the investigation of the link between CTs and precipitation, LWT has been used extensively and especially for continental Europe (e.g. Goodess and Palutikof, 1998; Trigo and DaCamara, 2000; Linderson, 2001; Lrenzo et al., 2008; Brisson et al., 2011; Baltacı et al., 2015 (16 MSLP grid points in Figure 1.1b).

In addition to characterize the precipitation climate based on the atmospheric CTs, the relationship between teleconnection patterns (TPs) and precipitation in a region or county were investigated in many studies in the continental Europe. Main TPs (or circulation indices) in the researches are known as the North Atlantic Oscillation (NAO), Arctic Oscillation (AO), East Atlantic-West Russia (EAWR) and Scandinavian (SCA) patterns (Figure 1.1a). In addition to the investigation the influences of teleconnection patterns and/or CTs on precipitation, numerous studies have endeavored to classify climate zones by using cluster analysis methods.

\subsection{Motivation}

Numerous studies have been conducted concerning precipitation in and around Anatolian Peninsula. Some of these deal with its spatial (Erinç, 1962; Türkeş, 1996; Ünal et al., 2003; Sönmez and Kömüşcü, 2011; Sahin and Cigizoglu, 2012) and temporal (Toros, 2012; Ünal et al., 2012) variability, while others assess its variations in response to teleconnection patterns such as North Atlantic Oscillation (Cullen and deMenocal, 2000; Türkeş and Erlat, 2003), or the North Sea-Caspian Pattern (Krichak et al., 2002; Kutiel et al., 2002); or to the hypothetical changes in sea surface temperatures (Bozkurt and Şen, 2011). According to the climate change simulations, Marmara Region (NW part of Turkey) is more sensitive to climate change due to the added stressors of land-cover change and rapid urbanization (Ezber et al., 2007; Sertel et al., 2011). With approximately 23 million people, the region is the most populated area of Turkey. The region consists of 11 cities, and four of them (Istanbul, Bursa, Kocaeli, and Balıkesir) have more than one million people. The population density (people per $\mathrm{km}^{2}$ ) in this region is 250 which is $\sim 2.5$ times denser than average of Turkey, and it can reach up to 3000 in Istanbul. Istanbul is the economic capital of Turkey, and the Marmara Region plays a significant role in 
industry, tourism, trading, and agricultural sectors of the country. Therefore, sudden spatial and/or temporal changes in precipitation amounts profoundly affect the socioeconomic development of Turkey.

(a)
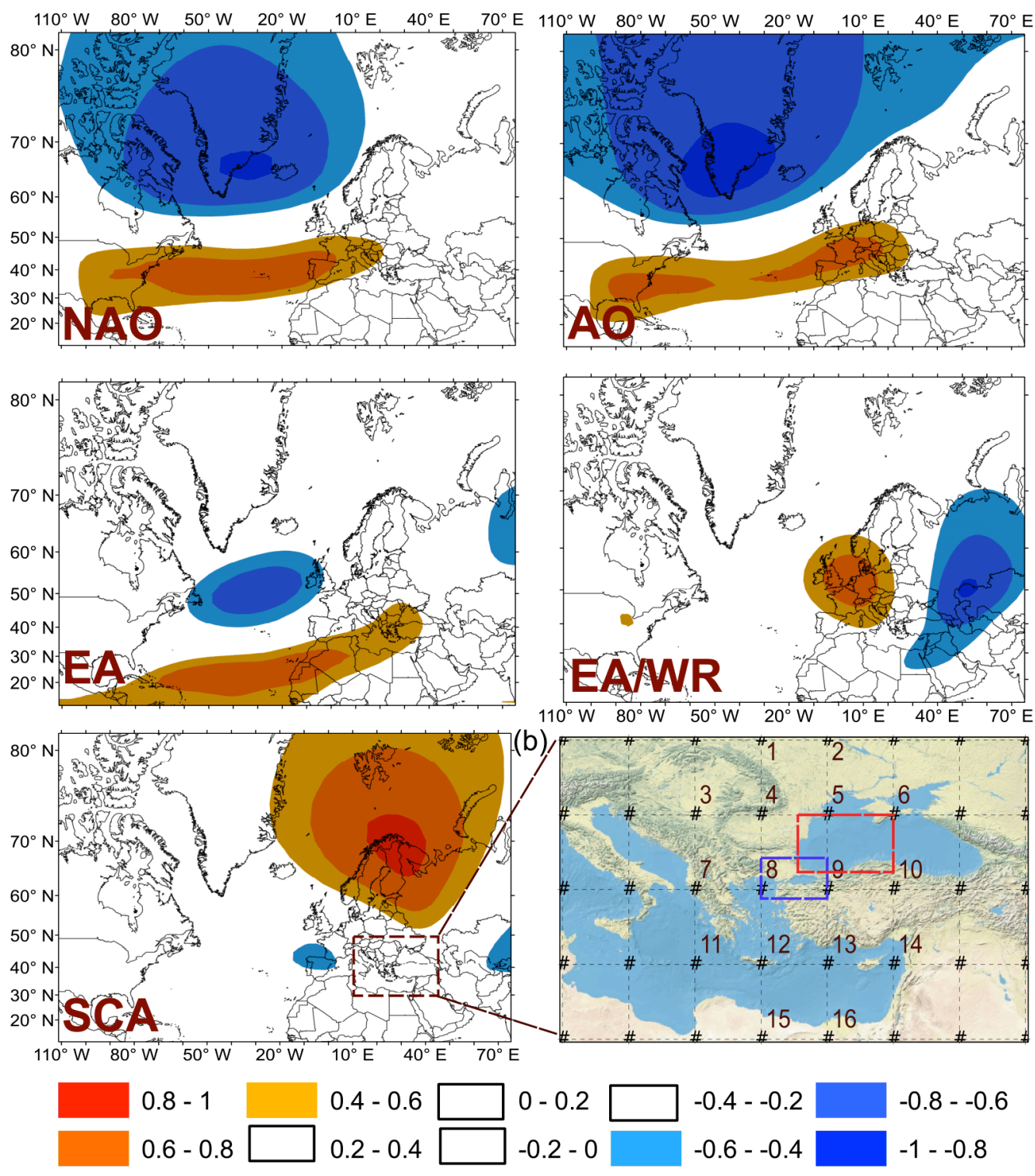

Figure 1.1 : (a) Spatial locations of the main teleconnection patterns (TPs). The figures represent the correlation between winter (DJF) $500 \mathrm{hPa}$ monthly standardized height anomalies and winter TPs index values from 1971 to 2012. (b) The 16 MSLP grid points used for classification of CTs. The dashed rectangles show Marmara Region (blue) over the NW part of the Anatolian Peninsula and the areal extent of SST (red). 


\subsection{Purpose}

In terms of teleconnection patterns, only the correlations between index values and precipitation amounts were studied for Turkey (e.g. Türkeş and Erlat, 2003; Türkeş and Erlat, 2005). In regard to the synoptic circulations, Erinç and Sungur (1964) studied weather types in Istanbul by classifying daily local observations such as temperature, relative humidity, precipitation amount, wind speed and direction. Except their work, either the types of synoptic circulation (CTs) in Turkey or their relationship with precipitation was not studied in detail. For the defining of precipitation climates of the country, numerous studies were implemented to the precipitation values by using Ward's, K-means, and spectral clustering methodologies (Ünal et al., 2003; Türkeş and Tatli, 2011; Sönmez and Kömüşcü, 2011; Sahin and Cigizoglu, 2012). For the first time, the goal of this study is to improve our understanding of the precipitation characteristics and its spatial variability in Marmara Region, in relation with CTs and in response to the complex topography of the area. In the second part, in addition to the temporal variation of CTs and trends in the occurrence frequencies of these CTs and how their precipitation potentials change in time, the linkage of the synoptic-scale variability and the large-scale modes of climate variability and regional climates of Marmara was clarified. The significances of CTs that quantitatively cause precipitation occurrence and intensity in the sub-basins of the Marmara region were investigated at the last step. 


\section{STUDY BASIN}

\subsection{Precipitation Climate of the Marmara Region}

To identify annual and seasonal precipitation characteristics of the Marmara Region, daily rainfall data, from 22 stations (Figure 2.2) operated by the Turkish State Meteorological Service, were used for the period of 1971-2010. According to these rainfall data, Marmara Region is an area of transition between summer-dry Mediterranean and year-round-wet Black Sea precipitation regimes (Türkeş, 1996). In addition, its complex coastline and rugged topography (with heights varying from sea level to the 2600-m Mount Uludağ in SE) lead to a highly inhomogeneous spatial distribution of rainfall (Figure 2.2). Stations located in the south and west of the area exhibit a rather Mediterranean type of annual precipitation distribution (Ünal et al. 2003 ) with low amounts of rainfall in JJA; totaling, for instance, an average of 36 $\mathrm{mm}$ in Balıkesir, and making up 6\% of the annual sum. On the other hand, stations in the NE are remarkably wetter during summer months: Sakarya receives and average of $165 \mathrm{~mm}$ JJA rain, equivalent to $20 \%$ of its annual total. As shown in Figure 2.2, these differences are well reflected in mean annual precipitation (MAP hereafter) values, which varies between 460 and $944 \mathrm{~mm}$, with the highest values observed at stations closer to the Black Sea. This is also where the average number of rainy days per year is the highest (not shown). The area around Bilecik and the interior part of the Trakya basin (NW of the region Marmara - a major agricultural area), which both have rain shadow character, have the lowest MAP values. In all stations, 30$50 \%$ of MAP falls in DJF, with the highest percentage in southern stations (not shown). SON is the second rainiest season. In MAM, precipitation is mainly convective, resulting in a seasonal maximum at elevated stations located inland, such as Keles.

As wettest season, DJF precipitation have significant role on determining the precipitation characteristics of the region. Therefore, more detail information is needed to identify DJF precipitation. For this reason, we extracted spatial and temporal DJF precipitation properties using long-term (1960-2012) 19 homogenized 
meteorological stations. In order to understand the spatial distribution of wintertime precipitation over years, its average percentage contribution to MAP, the average number of wet days and threshold values according to the T10 method (Osborn et al., 2000; Burt and Ferranti, 2012) were extracted for 19 stations. The T10 threshold was defined for each station separately, which is the daily rainfall amount that corresponds to the top $10 \%$ of ranked cumulative rainfall for the reference period (1960-2012). It is shown in Table 2.1 that the lowest winter rainfall totals are recorded for the NW part of the region, which is the agricultural basin (e.g. Kırklareli, Lüleburgaz, Edirne). Highest winter rainfalls are shown for seaside stations close to the Marmara Sea and the Black Sea (e.g. Şile, Çınarcık, Kireçburnu). The percentage contribution of winter (DJF) precipitation to the MAP changes from 31.1 to $44.1 \%$ in the Marmara stations. Every other day produces rainfall located in the north and northeast part of the studies area. Interestingly, although DJF rainfall totals are minimal at Kirklareli, threshold values dropped to 42 $\mathrm{mm}$. This indicates that the magnitude of the daily precipitation is higher than that of the neighboring stations.

Tablele 2.1 : Geographic coordinates, altitudes, and the DJF precipitation characteristics of the stations for the period from 1960 to 2012.

\begin{tabular}{lccccccc}
\hline \hline Station & $\begin{array}{l}\text { Lat. } \\
(\mathrm{N})\end{array}$ & $\begin{array}{l}\text { Lon. } \\
(\mathrm{E})\end{array}$ & $\begin{array}{c}\text { Alt. } \\
(\mathrm{m})\end{array}$ & $\begin{array}{l}\text { DJF } \\
\text { prep. }\end{array}$ & $\begin{array}{l}\text { Contribution } \\
\text { to MAP }(\%)\end{array}$ & $\begin{array}{l}\text { DJF } \\
\text { wet days }\end{array}$ & $\begin{array}{l}\text { DJF } \\
\text { thresholds }\end{array}$ \\
\hline Bandırma & 40.35 & 27.97 & 58 & 299.3 & 41.6 & 46 & 49.0 \\
Bursa & 40.18 & 29.07 & 100 & 267.3 & 38.3 & 43 & 37.7 \\
Çanakkale & 40.15 & 26.42 & 6 & 271.5 & 44.1 & 35 & 47.8 \\
Çınarcık & 40.65 & 29.12 & 20 & 314.0 & 35.8 & 44 & 51.9 \\
Çorlu & 41.17 & 27.80 & 183 & 193.8 & 33.8 & 44 & 30.9 \\
Edirne & 41.67 & 26.57 & 51 & 185.3 & 31.4 & 36 & 36.5 \\
Florya & 40.98 & 28.75 & 36 & 255.0 & 39.3 & 46 & 32.0 \\
İpsala & 40.93 & 26.40 & 10 & 224.9 & 35.9 & 33 & 42.8 \\
Keles & 39.92 & 29.07 & 1063 & 295.0 & 39.2 & 44 & 40.8 \\
Kireçburnu & 41.17 & 29.04 & 58 & 312.7 & 37.7 & 51 & 35.5 \\
Kurklareli & 41.73 & 27.23 & 232 & 178.9 & 31.9 & 32 & 42.0 \\
Kocaeli & 40.78 & 29.93 & 76 & 277.2 & 34.3 & 50 & 35.2 \\
Kumköy & 41.25 & 29.03 & 30 & 298.1 & 36.7 & 47 & 41.2 \\
Lüleburgaz & 41.40 & 27.35 & 46 & 179.3 & 31.1 & 27 & 37.3 \\
Malkara & 40.90 & 26.92 & 283 & 248.6 & 36.1 & 34 & 41.1 \\
Sakarya & 40.78 & 30.42 & 31 & 275.5 & 32.9 & 46 & 31.2 \\
Şile & 41.18 & 29.61 & 31 & 300.0 & 35.5 & 49 & 42.0 \\
Tekirdağ & 40.98 & 27.55 & 4 & 206.6 & 35.3 & 35 & 37.5 \\
Yalova & 40.65 & 29.27 & 4 & 282.3 & 37.7 & 45 & 38.8 \\
\hline
\end{tabular}


In order to understand the temporal behavior of the winter mean precipitation for the region, weighted averages of DJF precipitation totals and their annual anomalies were calculated using data for the 19 meteorological stations. As shown in Figure 2.1, the three driest periods occurred during 1972, 1989, and 1992, respectively. On the other hand, the three wettest periods occurred in 1963, 1981, and 2010, respectively. According to the 10-year moving average, a sharp decrease in DJF precipitation can be observed during the late 1970s, followed by an increasing trend in the 1980s. From the late 1990s to today, an increasing trend of precipitation can be observed in the region.

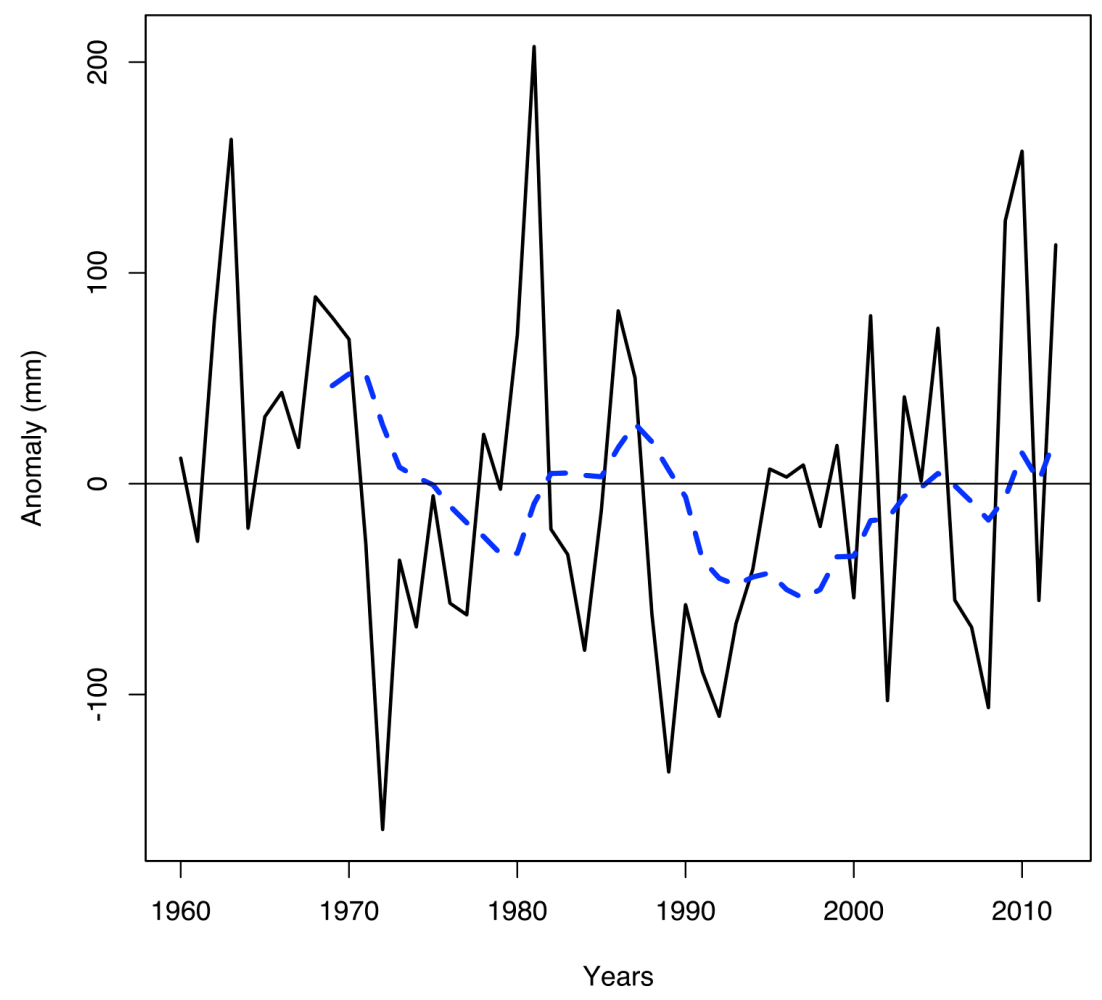

Figure 2.1 : Winter (DJF) precipitation anomalies of Marmara for the period from 1960 to 2012. Dashed lines indicate the 10-year moving average.

\subsection{General Overview to Classification Methods}

Many climatological studies and applications need the data set to be simplified by dividing data points into a relatively small number of distinct categories. In atmospheric circulations, numerous methods were developed. For example, classified can be backward air trajectories, cyclone tracks, and wind fields. A circulation implies a field of sea level pressure, geopotential height, or another variable describing atmospheric circulation in the particular time scales such as hour, day or 
month. These classifications are called as 'circulation classifications' and for individual classes are referred as 'circulation types'. The vast majority of circulation classifications use sea level pressure (SLP) and/or geopotential heights in lower to middle troposphere defined on a regular latitude-longitude grid. In literature, there is a wide variety of approaches and methodologies to classify circulation patterns. (Huth et al., 2008 and references therein). Each classification consists of two major steps: the definition of types and the assignment of individual cases to the types. Concerning the definition of types, there is a main distinction between approaches where the types are defined prior to the assignment stage and where the types are derived and evolve during the process of classification itself. The a priori definition of types can be grouped into the expert knowledge and physical or geometrical considerations (e.g. direction of flow) such as Lamb catalog. In our study, due to the widely usage of the objective version of Lamb Weather Type in literature, we investigated the influence of atmospheric circulation types on the precipitation climate of Marmara.

\subsection{Determining the CTs: Lamb Weather Types Methodology}

Automated Lamb Weather Types (LWT) methodology (Jenkinson and Collison, 1977; Jones et al., 1993) is based on Lamb's work (Lamb, 1972), who had developed a subjective classification scheme of CTs influencing The British Isles. In the objective (i.e. automated) version, sea level pressure fields are used to determine the direction and vorticity of geostrophic flow over a predetermined central point. This is done by calculating six circulation parameters and classifying them according to certain thresholds (see below). As a result, 27 different CTs are defined, of which eight are pure directional and two are vorticity types. Sixteen of the 17 remaining CTs are the combination of directional and vorticity types, hence they are named as hybrid. One last CT is for the 'unclassified'.

In the current application of the method, daily mean MSLP values (averaged from the 6-hourly NCEP/NCAR reanalysis data, Kalnay et al., 1996) on 16 grid points (between $5^{\circ} \mathrm{W}-55^{\circ} \mathrm{E}$ and $30^{\circ} \mathrm{N}-60^{\circ} \mathrm{N}$, Figure 2.2), centered over Marmara Region and separated by $5^{\circ}$ from each other, are used to determine the daily CTs. Chosen period is $1971-2010$, identical to that of precipitation data. The six parameters, namely the westerly flow (WF), southerly flow (SF), resultant flow (FF), westerly shear vorticity 
(WSV), southerly shear vorticity (SSV) and total shear vorticity (ZZ), are computed through the following formulae (Trigo and DaCamara, 2000):

$$
\begin{gathered}
W F=\left[\frac{1}{2}\left(p_{12}+p_{13}\right)-\frac{1}{2}\left(p_{4}+p_{5}\right)\right] \\
S F=1.305\left[\left(\frac{1}{4}\left(p_{5}+2 * p_{9}+p_{13}\right)-\frac{1}{4}\left(p_{4}+2 * p_{8}+p_{12}\right)\right]\right. \\
F F=\left(W F^{2}+S F^{2}\right)^{0.5} \\
W S V=1.12 *\left[\frac{1}{2}\left(p_{15}+p_{16}\right)-\frac{1}{2}\left(p_{8}+p_{9}\right)\right]-0.91 *\left[\frac{1}{2}\left(p_{8}+p_{9}\right)-\frac{1}{2}\left(p_{1}+p_{2}\right)\right] \\
S S V=0.85 *\left[\begin{array}{l}
\left.\frac{1}{4}\left(p_{6}+2 * p_{10}+p_{14}\right)-\frac{1}{4}\left(p_{5}+2 * p_{9}+p_{13}\right)-\frac{1}{4}\left(p_{4}+2 * p_{8}+p_{12}\right)\right] \\
+\frac{1}{4}\left(p_{3}+2 * p_{7}+p_{11}\right)
\end{array}\right] \\
Z=W S V+S S V
\end{gathered}
$$

where $p_{\mathrm{i}}$ is the normalized daily mean MSLP value at grid point $i$ (Figure 2.2). Grid point values of each day were normalized as it was done by Linderson (2001). The latitude dependent coefficients in Equation (2), (4) and (5) (Jones et al., 1993) are identical to those in Trigo and DaCamara (2000), as the latitudes of 16 grid points used are also identical. Finally, classification of CTs is done according to the following criteria:

- Direction of a CT $(N, N E, E, S E, S, S W, W$ or $N W)$ is determined by $\tan ^{-}$ ${ }^{1}\left(\mathrm{WF} / \mathrm{SF}\right.$ ), adding $180^{\circ}$ to the final value if WF is positive. $45^{\circ}$ is allocated for each sector.

- If $|\mathrm{Z}|<\mathrm{FF}$, i.e. if the magnitude of total shear vorticity is less than the resultant flow, $\mathrm{CT}$ is one of the eight pure directional types listed above.

- If $|\mathrm{Z}|>2 \mathrm{FF}$, i.e if the magnitude of total shear vorticity is much greater than the resultant flow, the CT is either Cylonic or Anticyclonic.

- If $\mathrm{FF}<|\mathrm{Z}|<2 \mathrm{FF}$, the $\mathrm{CT}$ is one of the 16 hybrid types: a combination of directional and vorticity types.

- If $|\mathrm{Z}|$ or $\mathrm{FF}<6$, then the $\mathrm{CT}$ is 'unclassified' (Demuzere et al., 2009).

For practical purposes and the simplification of the analysis, each of the 16 hybrid types was incorporated, with a weight of 0.5 , into the corresponding pure directional and vorticity types (Trigo and DaCamara, 2000). For example, a day with a cyclonic- 
southwesterly (CSW) type (hybrid) was counted as a $0.5 \mathrm{C}$ (vorticity) and $0.5 \mathrm{SW}$ (directional) day. The very few $(<1 \%)$ cases of 'unclassified' were also disseminated among main types, as it was done by Trigo and DaCamara (2000). Therefore only 10 main CTs were retained.

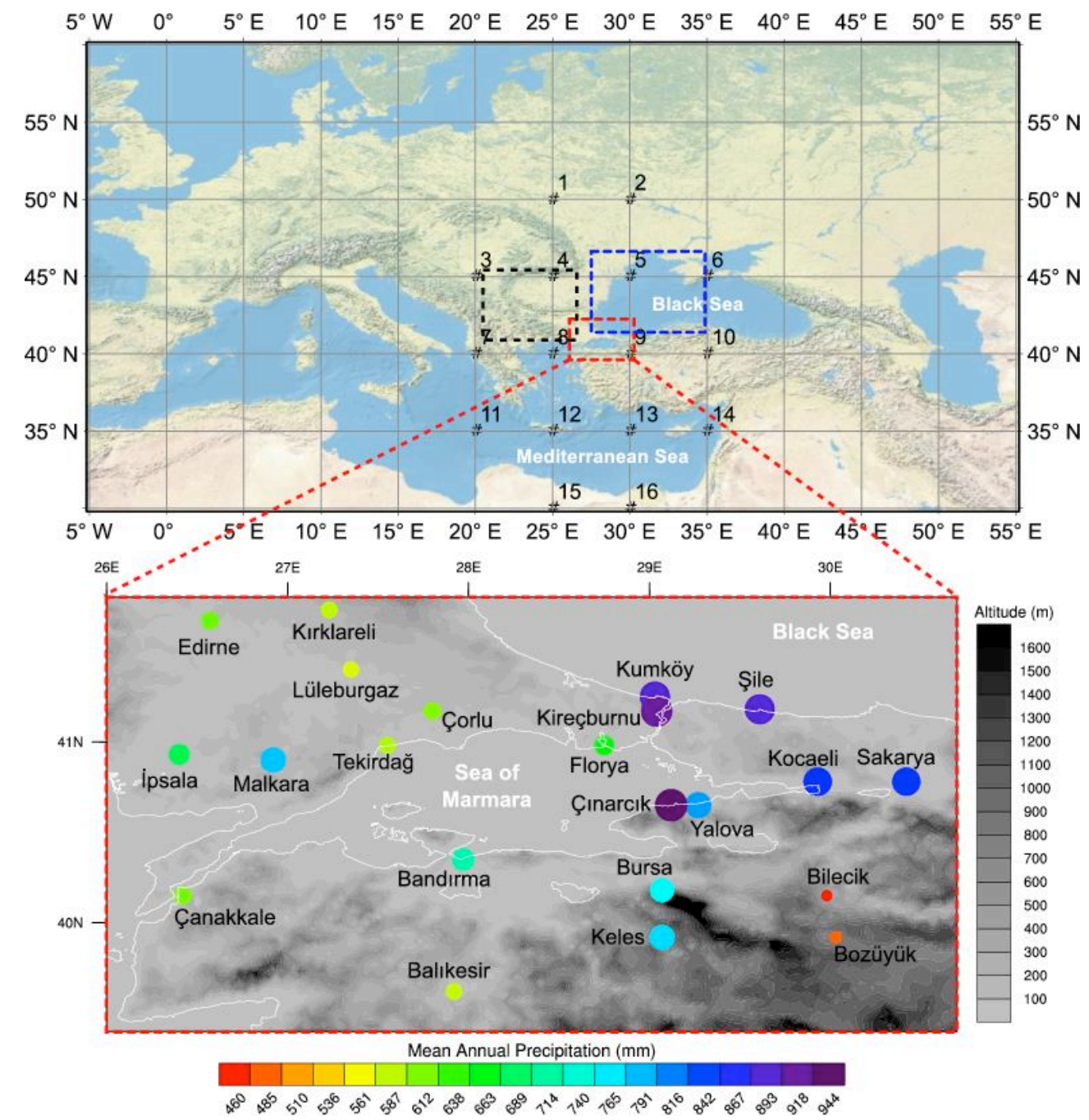

Figure 2.2 : (a) The 16 MSLP grid points used in the Lamb Weather Type analysis. Of the smaller (dashed) rectangles, the lower one covers the Marmara Region; whereas the upper right and upper left show the areal extent of sea surface temperature and specific humidity data respectively. (b) Marmara Region and its topography, along with locations, names and mean annual precipitation values of the meteorological stations used in the analysis. The size of each dot is proportionate with the mean annual precipitation. 


\subsection{Teleconnection Patterns}

In terms of the TPs, the prevalent pattern, NAO (first defined by Walker, 1924) is described the varying strength of the relationship between Azores high pressure and Iceland low pressure center in the North Atlantic Basin, defined as positive (high pressure gradient) or negative (weaker pressure gradient) index phases and is the only atmospheric mode that observed throughout the whole year in the Northern Hemisphere (Hurrell et al., 2003). There are a large number of studies related NAO and its impact on the regional or local precipitation characteristics in the Europe (e.g. Rodriguez-Puebla et al., 2001; Munoz-Diaz and Rodrigo, 2003; Türkeş and Erlat, 2003; Trigo et al., 2004; Türkeş and Erlat, 2005; Bice et al., 2012). AO, which occurs in the Pacific, also shows the similar spatial characteristics with NAO and it is shown similar impacts on Mediterranean winter climate (Xoplaki, 2002). Zonally oriented EAWR pattern (or Eurasia pattern type 2-EU2, Barnston and Livezey, 1987) also have a critical importance for European precipitation. During winter, the anomaly centers over Caspian Sea and Western Europe comprise EAWR, and positive phases of its are associated with negative pressure anomalies throughout western and the southwestern Russia, and the positive pressure anomalies over northwestern Europe or vice versa. Krichak et al., (2002), and Krichak and Alpert (2005) investigated the role of EAWR pattern on precipitation of the Mediterranean Basin. There are also limited studies related with EA (the centers located near $55^{\circ} \mathrm{N}, 20-35$ ${ }^{\circ} \mathrm{W}$ and $25-35^{\circ} \mathrm{N}, 0-10^{\circ} \mathrm{W}$ ), and the Scandinavian pattern (or Eurasia pattern type 1EU1, the centers located over Scandinavia and northwest China (e.g. Dünkeloh and Jabobeit, 2003). Daily index values of each these five teleconnection patterns were obtained from the Climate Prediction Center of the NOAA (Url-1).

\subsection{Relation of CTs with Precipitation}

To link CTs with precipitation, we calculated daily mean rainfall potentials at each station during each of the CTs resulting from the LWT analysis. This was done simply by dividing the long-term cumulative precipitation observed during a CT by the total number of days within that CT. Seasonal and spatial variation of these potentials were assessed in relation with large-scale circulation and the topography of Marmara Region. Long-term average seasonal/annual precipitation totals at each 
station during each CT was also computed and examined. In addition to these, interaction of the relatively warm Black Sea with the advecting cold air during CTs with northerly components was investigated, as this is known to have an influence on precipitation. For this purpose, monthly differences between Black Sea SSTs and air temperature at $850-\mathrm{hPa}$ level $\left(\mathrm{T}_{850}\right)$ was calculated and compared with local precipitation amounts. Availability of upstream specific humidity was also taken into account during the assessment. Daily SST values covering the period of 1982-2010 were taken from NOAA High Resolution SST data (Url-2). As the MSLP values used for LWT analysis, $\mathrm{T}_{850}$ and specific humidity data (on various levels) were obtained from the NCEP/NCAR Reanalysis (Kalnay et al., 1996). 


\section{ATMOSPHERIC CIRCULATION TYPES IN MARMARA REGION}

\subsection{Synoptic Analysis of CTs Affecting Marmara Region}

We produced composite MSLP maps in order to understand the spatial characteristics of different CTs and their influence over Marmara Region, for the period of 1971-2010 (Figure 3.1). As described in the previous section, only the ten main CTs (eight directional and two vorticity types) were retained, by including the hybrid types into the corresponding directional and vorticity CTs. As a further simplification, these ten CTs can be subjectively grouped into three broad categories according to the spatial configuration of their large-scale MSLP anomalies. Category I consists of the types NE and E (Figure 3.2), whose distinguishing synoptic features are a prominent blocking high over Eastern Europe and a low centred in the Middle East (Figure 3.1). Accordingly, at least slightly positive MSLP anomalies are observed at the northern half of the Mediterranean basin along with Marmara Region; while MSLP over eastern Mediterranean Sea exhibits negative anomalies. Category II can be defined to include the southerly CTs (SW, S, SE), all of which have a low around Italy (Figure 3.1). MSLP around the Central Mediterranean and Aegean Seas take on negative anomaly values during Category II patterns. It is again slightly negative in the region Marmara, except for S pattern. The NW, N and W patterns constitute the Category III, during which a low is observed around the northern edge of the Black Sea. This configuration leads to negative MSLP anomalies over the Black Sea and the Marmara Region, except for $\mathrm{N}$ pattern. The remaining two CTs are the cyclonic and anticyclonic (vorticity) patterns, where a low and high are located, respectively, very close to the region of Marmara. In the subsequent sections of this study, in addition to the subjective categorization made above, the ten CTs will be assessed with respect to the character of air masses they advect (i.e. maritime or continental). This is a very important feature of CTs in terms of their precipitation potential (Trigo and DaCamara, 2000; Brisson et al., 2011). However, a strict categorization of CTs according to the maritime/continental flow 
distinction [such as the one made in Brisson et al., (2011)] was avoided in this study, as it would be problematic due to the complex topography of Marmara Region.

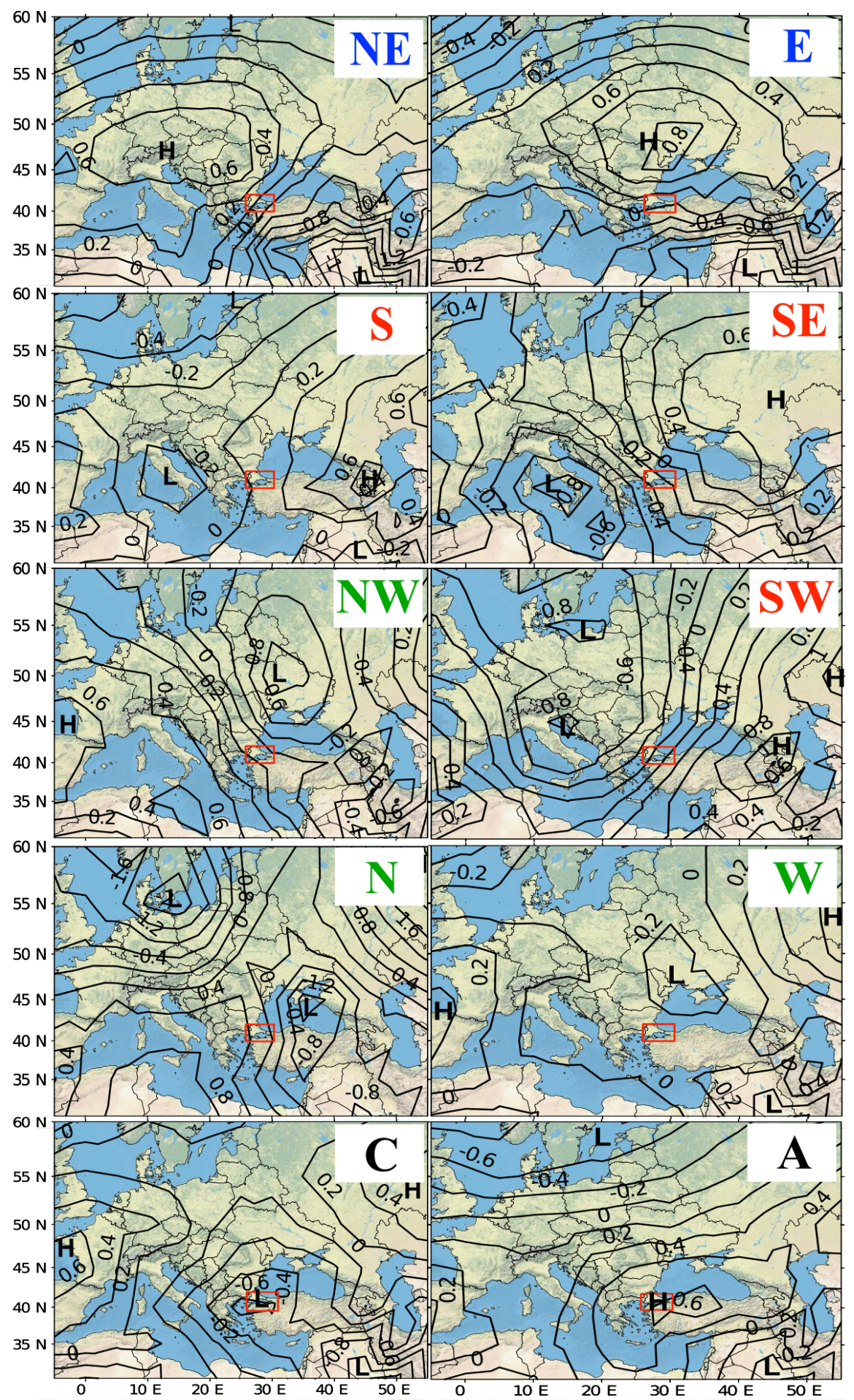

Figure 3.1 : Long term mean of normalized MSLP anomalies of each of the eight main directional and two vorticity CTs that affected Marmara Region during the period 1971-2010. H and L mark the high and low pressure centers. 


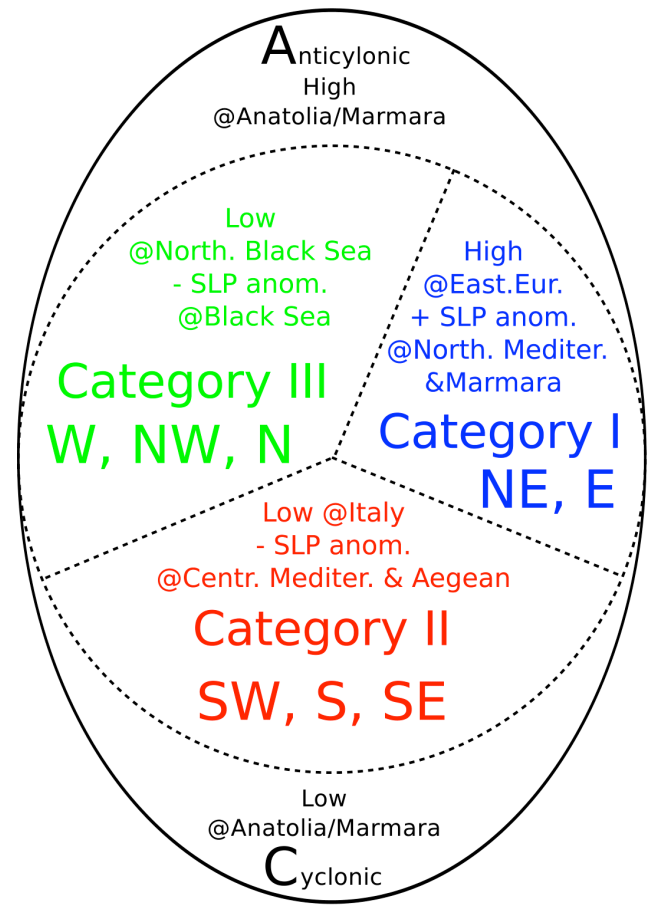

Figure 3.2 : Subjective re-categorization of the circulation types resulting from Lamb Weather Type analysis.

3.2 Frequency of CTs and Their Significance with Respect to Large-Scale Circulation

\subsubsection{Annual averages}

On an annual basis, almost one of every two days belongs to Category I (i.e. NE or $\mathrm{E})$. NE is the most frequently observed throughout the year (29\%), followed by the $\mathrm{E}$ (20\%) (Figure 3.3a). Category II CTs (S, SW and SE), when combined, are the second most frequent (23\%). Category III CTs $(\mathrm{N}, \mathrm{W}$ and $\mathrm{NW})$ are rather infrequent. 


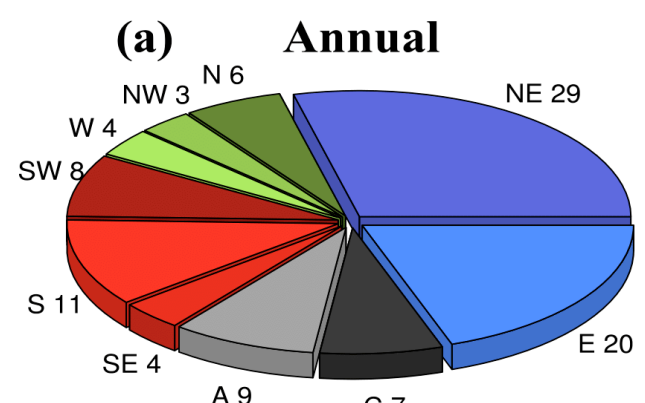

(b) DJF (Winter)

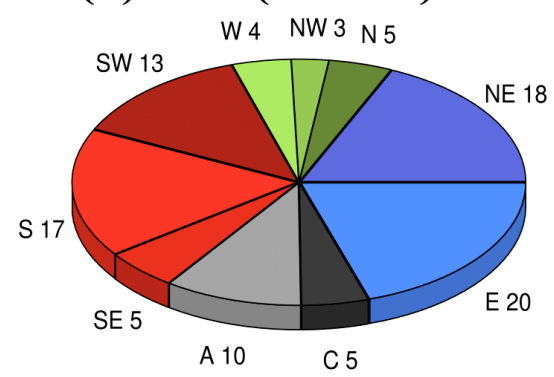

(d) JJA (Summer)

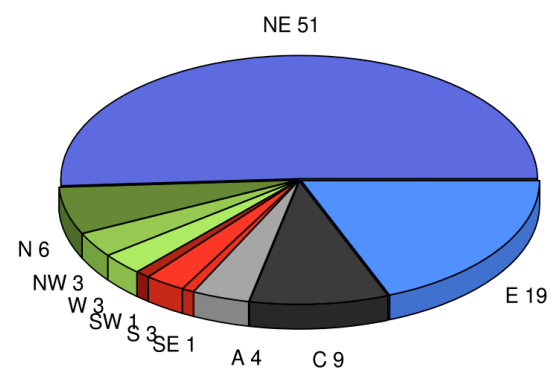

C 7 (c) MAM (Spring)

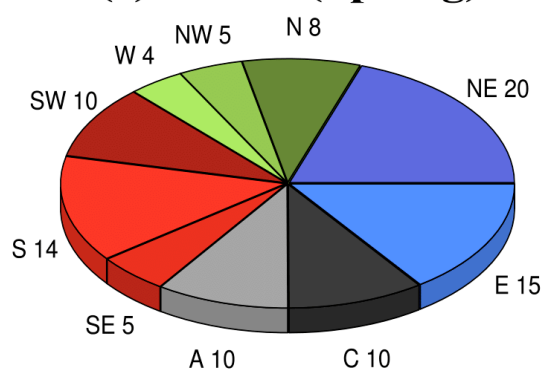

(e) SON (Fall)

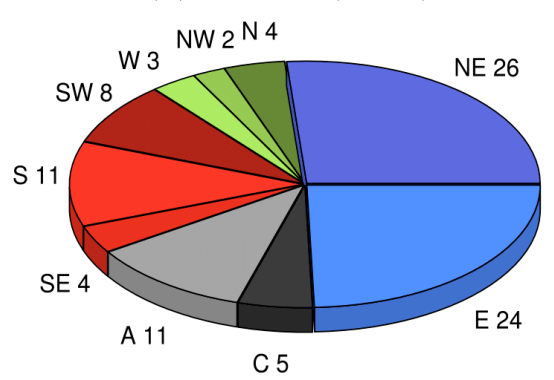

Figure 3.3 : Mean frequencies (in \%) of the ten main CTs during the period of 19712010. Hybrid types were merged into pure directional and vorticity types as described in the text.

\subsubsection{December, january, february}

In DJF, E and NE (Category I at Figure 3.2) are the most common [20\% and $18 \%$, respectively (Figure 3.3b], reflecting the dominant character of the blocking anticyclone centred over eastern Europe (Figure 3.1) in response to continental cooling, similar to the formation of Siberian High (Panagiotopoulos et al., 2005). However, the combined frequency of $\mathrm{E}$ and $\mathrm{NE}$ are not as high as on an annual basis (Figure 3.3a). This is due to the southerly (Category II: S, SW and SE) CTs, characterized by a low over Italy (Figure 3.1), becoming more frequent during DJF. The Mediterranean Basin and its borderlands turn into and area of cyclogenesis in this season (Trigo et al., 1999, 2002) leading to a general decrease of the MSLP in the region. Therefore, the total frequency of all southerly CTs increases to $35 \%$, 
(Figure $3.3 \mathrm{~b}$ ), which is $12 \%$ higher compared to their annual average of $23 \%$. The anticyclonic (A) pattern, during which the Anatolian peninsula is the centre of the high pressure anomaly, is the fifth most frequent (10\%) after E, NE, S and SW. Finally, the cyclonic $(\mathrm{C})$ type is the second least frequent pattern after NW.

\subsubsection{June, july, august}

During JJA, geostrophic flow over the region of Marmara is predominantly of the Category I: Types NE and E make up $69 \%$ of all CTs (Figure 3.3d), with the NE pattern observed every other day (51\%). Both NE and E feature a low pressure anomaly over the Middle East (Figure 3.1); clearly representing the dry, thermal surface low pressure forming in this area during JJA, which is and extension of the Asian monsoon (Maheras et al., 1999; Ziv et al., 2004; Ferranti and Viterbo, 2006; Garcia-Serrano et al., 2013). Under the influence of especially the NE pattern, the Marmara Region, particularly its northern and eastern parts, are invaded by moist and relatively cool air from the Black Sea, therefore it is mostly spared from excessive heat. The third most frequent CT of the JJA period is the type C (9\%), arising due to Anatolian peninsula itself turning into an area of thermal low at times, as an extension of the thermal low in the Middle East.

\subsubsection{Fall and spring}

The frequency distribution of CTs for the transition seasons is a blend of DJF and JJA, NE and E again being the most frequent in both SON and MAM (Figure 3.3ce). The other three most frequent patterns, namely A, S and SW, have percentages close to their annual averages.

\subsection{Relationship between CTs and Precipitation}

\subsubsection{Daily potentials}

\subsubsection{Wet atmospheric CTs}

Cyclonic (C) and category III (N, NW, W) patterns are the wet CTs. Mean daily precipitation amounts accompanied by each CT are presented in Figure 3.4. 


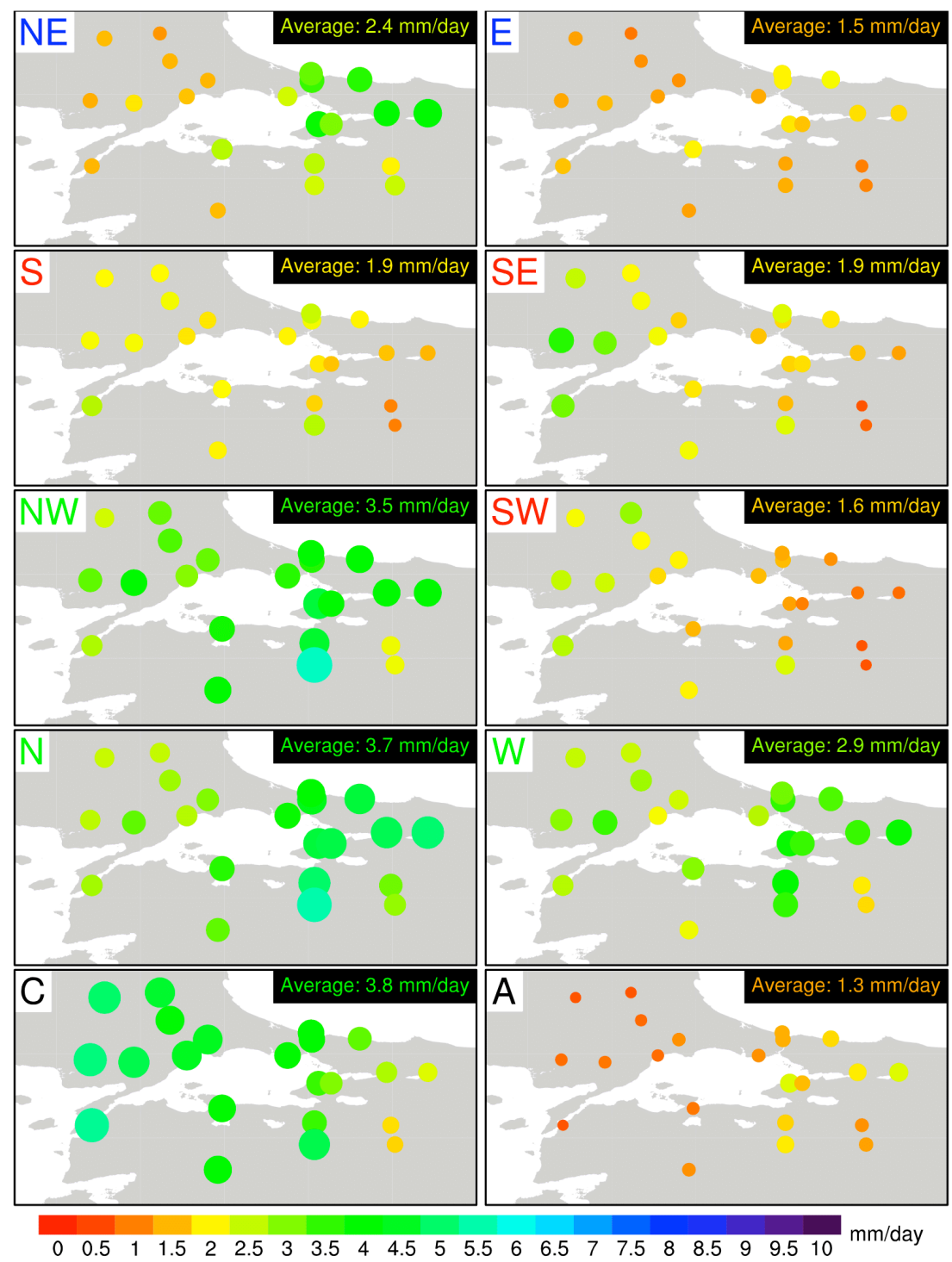

Figure 3.4 : Long term (1971-2010) mean of daily precipitation for each circulation type for the whole year. Size of the dots vary according to the precipitation rate. The top-right 'average' values are the spatial averages.

The Cyclonic (C) type is distinguishable from the others as being the wettest on average, with a regional mean value of $3.8 \mathrm{~mm} \mathrm{day}^{-1}$. High rainfall potentials during DJF (6.5 mm day ${ }^{-1}$, Figure 3.5) and SON (6.6 mm day ${ }^{-1}$, Figure 3.8) can be seen as a footprint of the Mediterranean low-pressure systems (Trigo et al., 1999, 2002). 


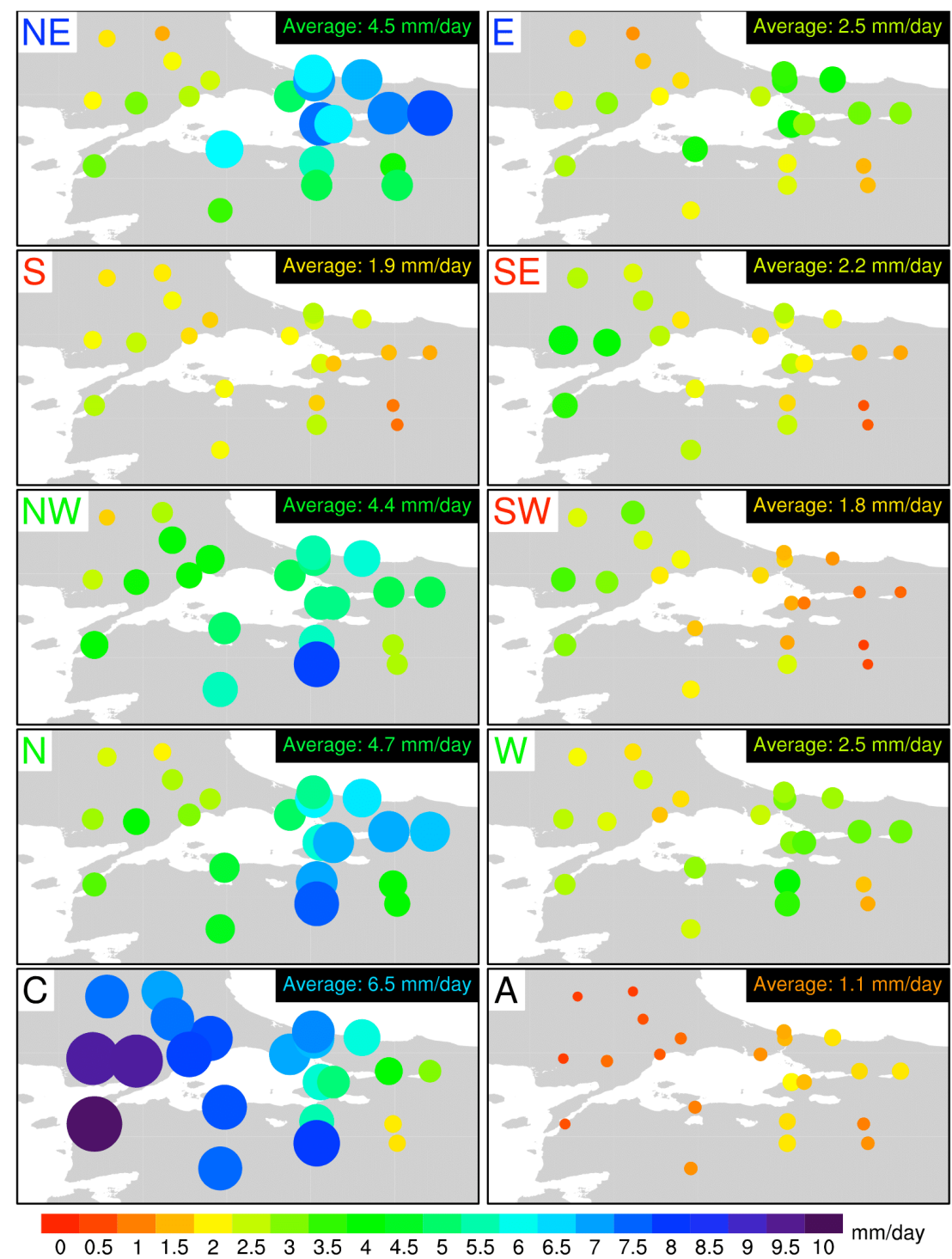

Figure 3.5 : For DJF (winter), long-term (1971-2010) mean of daily precipitation for each circulation type. Font colour of each CT is consistent with the categorization in Figure 3.2. Colour and size of the dots vary according to the precipitation rate. The top-right 'average' values are the spatial averages.

Greatest rainfall values are observed in the north and west of the region, as this is the cold and wet side of the surface low (Figure 3.1). Relatively low cyclonic rainfall in the two extreme southeastern stations (Bilecik and Bozüyük) is also a result of continentality and rain shadow character of this particular area (Figure 2.2), both of which operate during other CTs as well, making the two stations the driest of the region. 
The high interseasonal variability of the rainfall rate associated with the Cyclonic CT is also worth mentioning. While it is by far the wettest of DJF and SON; it is only the third wettest in MAM (3.6 mm day ${ }^{-1}$, Figure 3.6) and is relatively dry in JJA (1.2 mm day $^{-1}$, Figure 3.7). This contrasting behaviour can be explained by the dry character of the thermal lows, which form over Anatolia during warmer times of the year, along with other parts of the Eastern Mediterranean region as an extension of the Asian summer monsoon (Maheras et al., 1999; Ziv et al., 2004; Ferranti and Viterbo, 2006; Garcia-Serrano et al., 2013). After the Cyclonic, Category III CTs (N, NW and W) have the highest daily rainfall potential (Figure 3.4). These CTs are often associated with cold fronts and cyclone cold sectors over Marmara Region, as they all feature a low-pressure anomaly centred near the northern edge of the Black Sea (Figure 3.1). Of these three CTs, type $\mathrm{N}$ divides the region into two (as east and west) with regard to precipitation intensity, the eastern half becoming wetter on the annual average (Figure 3.4). This is not only because the eastern stations are closest to the cyclone centre during $\mathrm{N}$ (Figure 3.1), but is also a consequence of maritime advection which occurs from the full north-south fetch of the Black Sea towards the eastern half of the region. As a result, $\mathrm{N}$ is the wettest of Category III CTs and the second wettest of all types. The east-west precipitation discrepancy during $\mathrm{N}$ is especially obvious in SON and DJF (Figures 3.8 and 3.5), with the eastern stations becoming remarkably wetter than they are in other seasons. This implies a particularly enhanced moisture transport from the Black Sea during these seasons, an aspect that will further be elaborated in the next section. 


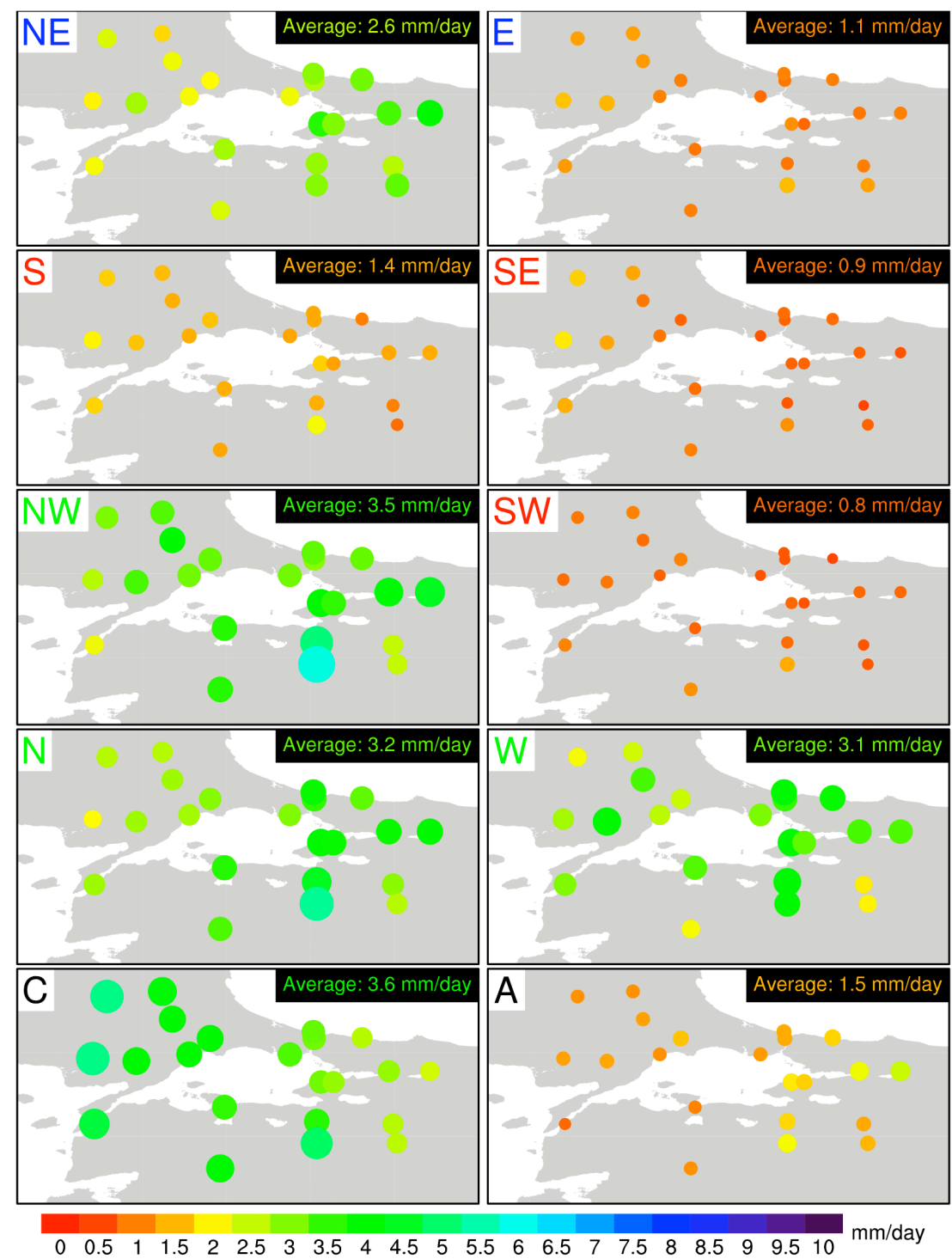

Figure 3.6 : For MAM (spring), long-term (1971-2010) mean of daily precipitation for each circulation type. Font colour of each $\mathrm{CT}$ is consistent with the categorization in Figure 3.2. Colour and size of the dots vary according to the precipitation rate. The top-right 'average' values are the spatial averages. 


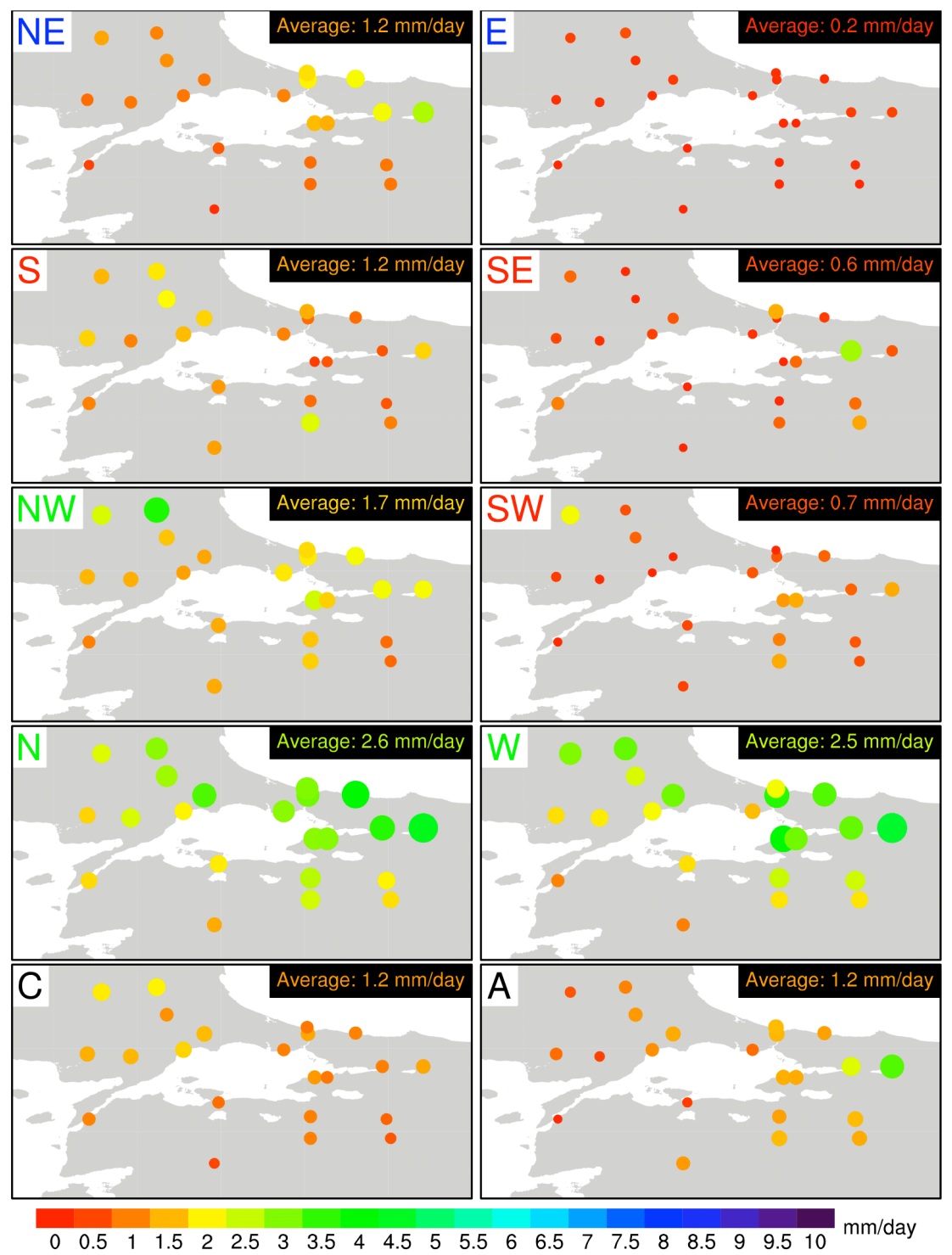

Figure 3.7 : For JJA (summer), long-term (1971-2010) mean of daily precipitation for each circulation type. Font colour of each CT is consistent with the categorization in Figure 3.2. Colour and size of the dots vary according to the precipitation rate. The top-right 'average' values are the spatial averages.

Type NW is somewhat similar to $\mathrm{N}$ in terms of the spatial distribution and regionally averaged amount of precipitation, though with a less obvious east-west difference. As the geostrophic wind gradually shifts to west for types NW and $\mathrm{W}$, moisture transport from the Black and Marmara seas diminishes due to a shortening of fetch distances over the Black Sea. Consequently, type W has no obvious east-west difference and types $\mathrm{N}$ and $\mathrm{NW}$ are much wetter than $\mathrm{W}$ in SON and DJF when moisture transport from Black Sea is more effective. Finally, slightly higher 
precipitation potentials of Category III CTs in SON compared to those in DJF probably owe to the higher values of upstream humidity in SON (Table 3.1).

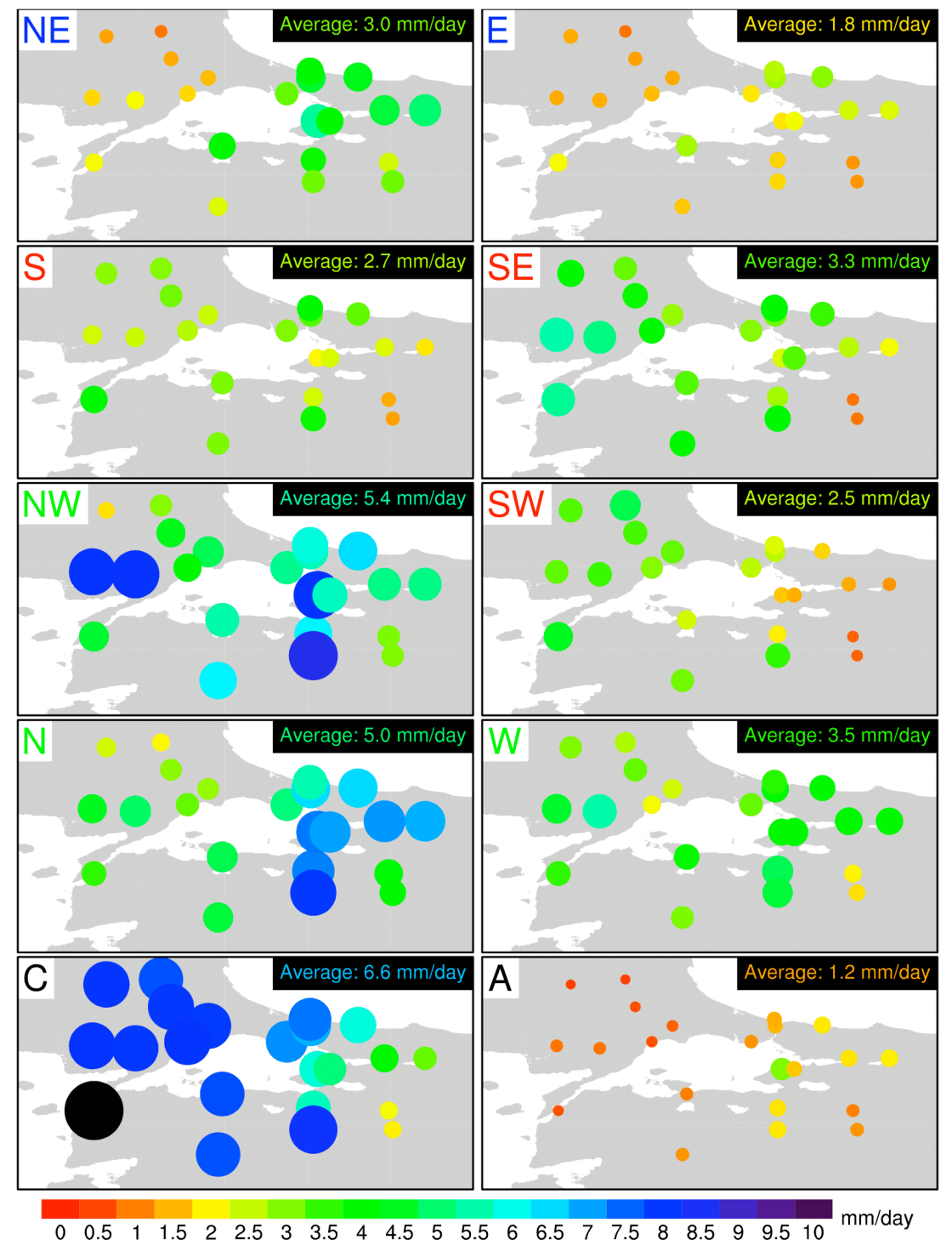

Figure 3.8 : For SON (fall), long-term (1971-2010) mean of daily precipitation for each circulation type. Font colour of each CT is consistent with the categorization in Figure 3.2. Colour and size of the dots vary according to the precipitation rate. The top-right 'average' values are the spatial averages.

Table 3.1 : Average specific humidity $\left(\mathrm{g} \mathrm{kg}^{-1}\right)$ at pressure levels $(\mathrm{mb})$ during type NW (1971-2010) at the NW of Marmara Region (see Figure 2.2 for the areal extent).

\begin{tabular}{lcccccc}
\hline Season & 1000 & 925 & 850 & 700 & 600 & 500 \\
\hline DJF & 4.49 & 3.47 & 2.49 & 1.39 & 0.88 & 0.71 \\
MAM & 7.36 & 5.68 & 4.17 & 2.14 & 1.19 & 1.00 \\
JJA & 10.72 & 8.35 & 6.53 & 3.50 & 1.91 & 1.54 \\
SON & 7.40 & 5.88 & 4.46 & 2.37 & 1.32 & 1.16 \\
\hline
\end{tabular}




\subsubsection{The sea-effect mechanism}

Following the Cyclonic and Category III CTs, NE has the greatest daily rainfall potential on the annual basis, while type E is the driest of all CTs after the type Anticyclonic. During DJF, NE is the third wettest (Figure 3.5), with its regional average (4.5 mm day ${ }^{-1}$ ) almost as high as that of $\mathrm{N}$, when even type $\mathrm{E}$ is the fifth wettest $\left(2.5 \mathrm{~mm} \mathrm{day}^{-1}\right)$. As it can be observed in Figure 3.1, NE and E feature a blocking high centred over Eastern Europe. This should lead to generally dry conditions in the region of Marmara, where the MSLP anomaly is also positive. However, the Black Sea is large enough to create 'sea-effect' precipitation for its borderlands (Erinç, 1962; Kındap, 2010; Bozkurt and Şen, 2011; Göktürk et al., 2011) in the absence of a nearby synoptic low. The Ne pattern is particularly favorable for sea-effect precipitation in Marmara Region, as the northeasterly winds find the longest fetch distance over the Black Sea to pick up humidity. Consequently, compared to the western half, type NE is remarkably wetter in the eastern half of the region, with the maximum rates observed at the northeastern locations close to the Black Sea (Figure 3.4 and Figures 3.5-3.8). This is also true for type N (one of the cold sector, Category III CTs explained in the previous section), in which the eastwest precipitation discrepancy is very similar to the one in NE. Further analyses were done in order to demonstrate the role of sea-effect mechanism in Marmara Region. The primary factor for the formation and intensity of sea-effect precipitation is known to be the temperature difference between sea surface and the air at $850-\mathrm{hPa}$ level (Holroyd, 1971; Niziol, 1987; Steenburgh et al., 2000). Accordingly, as the SST-T $_{850}$ difference becomes higher, convective instability and the chance of precipitation increase. Monthly variation of this parameter $\left(\mathrm{SST}-\mathrm{T}_{850}\right.$ ) over southwestern Black Sea during types N, NE and E indicates a maximum in November and December (Figure 3.9), followed by the other 4 months in DJF and SON. This is clearly reflected in the large daily precipitation potentials of NE during these seasons in the eastern half of Marmara Region (Figure 3.5 and 3.8). Moreover, during NE days, monthly average SST- $\mathrm{T}_{850}$ difference is strongly correlated to two precipitation metrics for the eastern stations. One of them is the monthly ratio of wet NE days to all NE days (Figure 3.10a), while the other is the monthly average of daily precipitation amount during NE days (Figure 3.10b). This obvious east-west 
contrast is a clear indicator of the role of the Black Sea in the precipitation regime in the region.

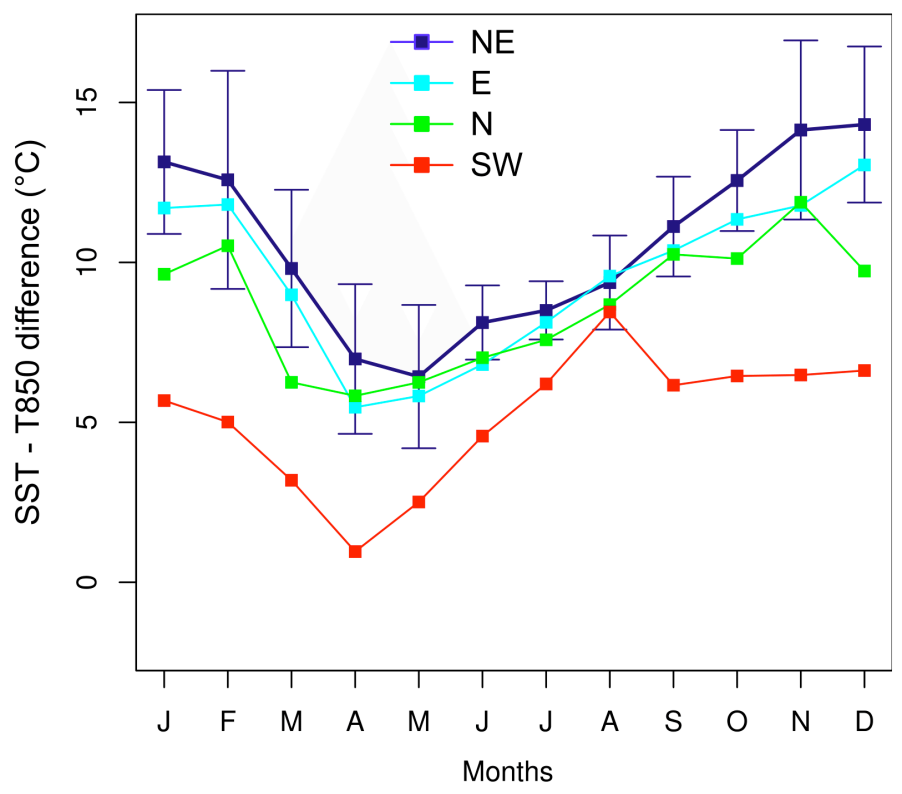

Figure 3.9 : Long-term (1982-2010) monthly means of differences between SSTs and the $850 \mathrm{hPa}$ temperature over the Black Sea (see Figure 2.2 for the areal extent) during selected CTs. Standard deviations are shown only for NE, to avoid confusion.

Although the daily precipitation potentials for type E are remarkably lower than those for NE, interseasonal variation of precipitation is very similar to that of NE. It shows a DJF-SON-MAM-JJA maximum-minimum sequence and implies a similar dependence of wet conditions on the sea-effect mechanism. Wettest stations during type E are located on the immediate Black Sea coast, the only location where easterly winds advect maritime air. 

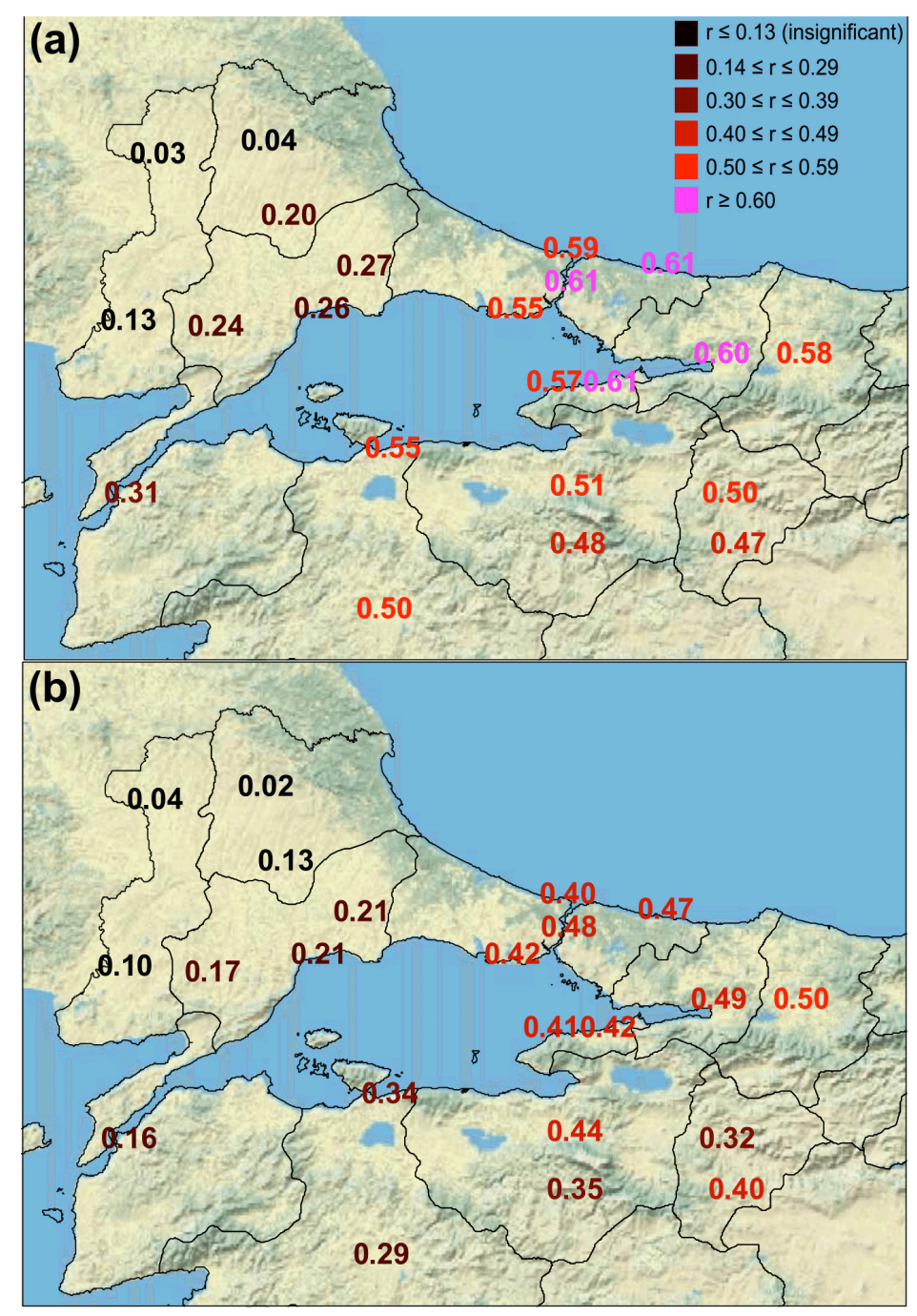

Figure 3.10 : Pearson's correlation coefficients $(r)$ between monthly average SST$850 \mathrm{hPa}$ temperature difference over the Black Sea during type NE and (a) monthly

ratio of wet NE days to all NE days, (b) monthly average of daily precipitation amount during NE days. Correlations greater than 0.14 are statistically significant at the 0.99 confidence level according to Student's $t$-test. The period is 1982-2010. See

Figure 2.2 for the areal extent of SST and $850 \mathrm{hPa}$ temperature.

\subsubsection{Wet western Marmara}

At times of Category II CTs (SW, S and SE) geostrophic wind over Marmara Region has a southerly component owing to the negative MSLP anomaly centred around Italy (Figure 3.1). After A and E, these CTs have the least regionally averaged potential to create precipitation, as nearby Black Sea is now eliminated from being a moisture source. Nevertheless, SW and SE provide some stations in the western part of the Marmara Region with a significant amount of rainfall (up to $6 \mathrm{~mm} \mathrm{day}^{-1}$ in Malkara) during SON and DJF. These two patterns, SW and SE, have a much more 
negative MSLP anomaly around Italy compared to S. Therefore they lead to a negative MSLP anomaly in western Marmara, and in turn, to more precipitation during SON and DJF associated with depressions. SST-T850 parameter during SW is too low to trigger sea-effect mechanism over Aegean Sea (Figure 3.9).

\subsubsection{Contributions to precipitation}

In Figure 3.11, the long-term (1971-2010) mean percentage contributions of the ten main CTs to the regionally averaged precipitation in Marmara Region during each season are shown.

\subsubsection{Regional averages}

Pursuant to their high over all frequency (Figure 3.3), the NE and E patterns (Category I) are the dominant weather types during wet days (Figure 3.11), although they do not have the highest rainfall potential for most stations in Marmara Region (Figure 3.4). On average, $45 \%$ of the annual, $46 \%$ of DJF and SON precipitation (Figure 3.11) occur during NE or E. The Category II patterns (SW, S and SE) supply $17 \%$ of annual and $22 \%$ of DJF precipitation amounts, owing to their relatively high frequency during winter. Despite their high rainfall potential, Category III CTs (N, $\mathrm{W}$ and NW) and the cyclonic (C) type provide only $24 \%$ of the annual and $20 \%$ of DJF precipitation.

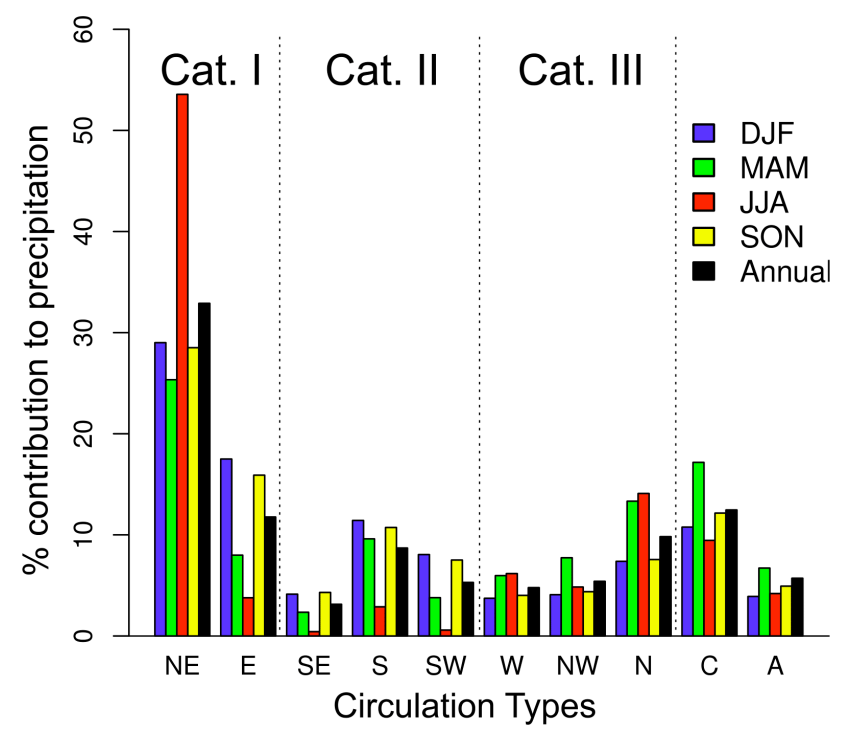

Figure 3.11 : Long-term (1971-2010) mean contributions (as percentage to each seasonal total) of each of the ten main CTs to the regionally averaged precipitation. 


\subsubsection{East-west contrast}

If the Marmara stations are analysed individually in terms of CT contributions to rainfall, the difference between east and west are as clear as for their rainfall potentials. Figure 3.12 compares Kırklareli (a western station) with Sakarya (an eastern one). The contrast is most obvious in the contribution of Category II (southerly) CTs. As Kirklareli is much closer to the Mediterranean low pressure anomaly of Category II, it receives almost $40 \%$ of its DJF precipitation during CTs with a southerly component. On the other hand, more than $60 \%$ of DJF precipitation in Sakarya is supplied by Category I (NE and E), again, reflecting the dominance of the local influence of the Black Sea.

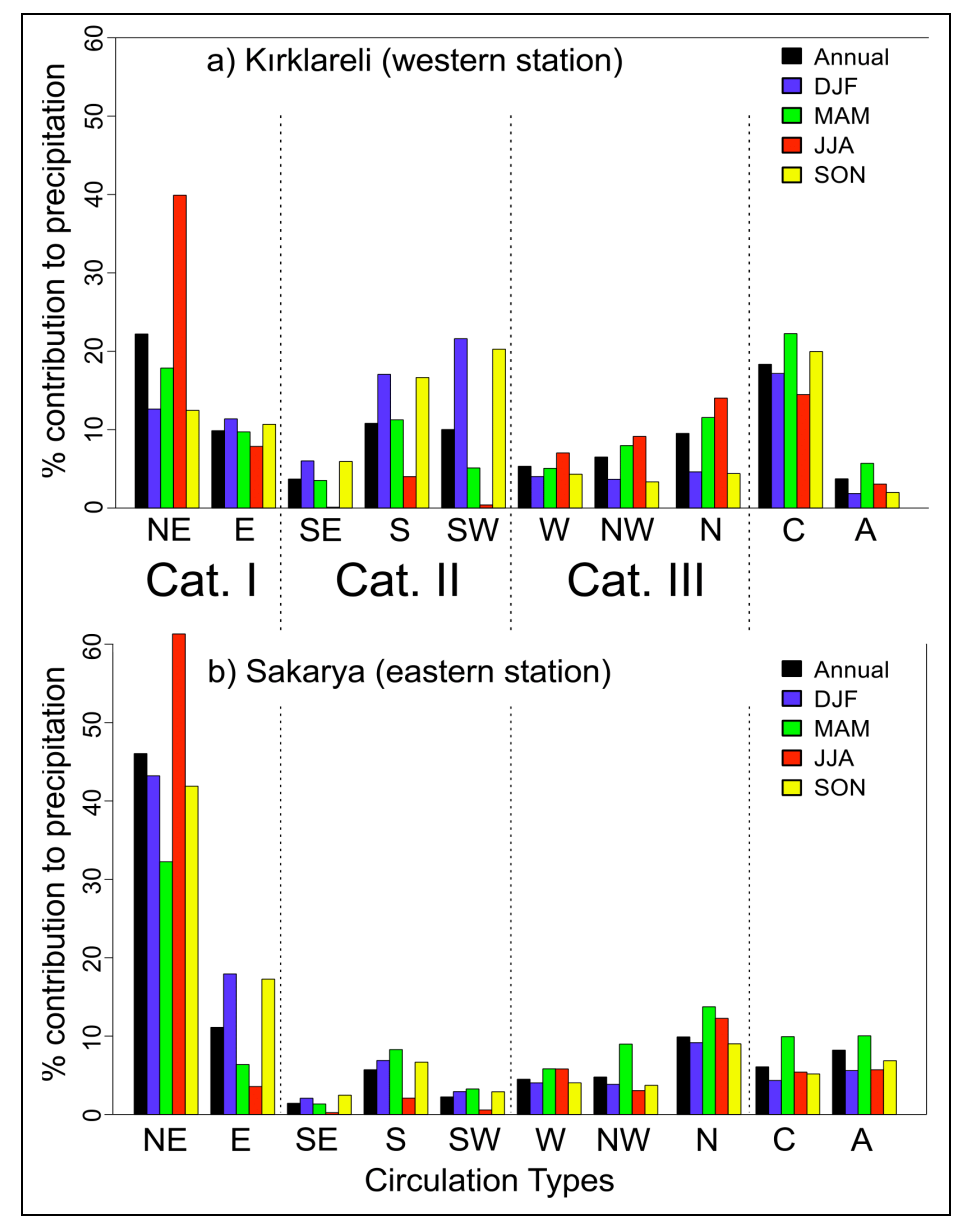

Figure 3.12 : Long-term (1971-2010) mean contribution (as percentage to each seasonal total) of each of the ten main CTs to the precipitation at stations (a) Kirklareli (western station) and (b) Sakarya (eastern station). 


\section{TEMPORAL VARIATIONS IN THE FREQUENCY AND PRECIPITATION POTENTIALS OF ATMOSPHERIC CTS IN MARMARA REGION AND ASSOCIATION WITH TELECONNECTION PATTERNS}

\subsection{Temporal Rainfall Distribution}

Daily rainfall data covering the period of 1971-2012 from 22 stations in Marmara Region (Figure 2.2b), obtained from the Turkish State Meteorological Service (TSMS), were used to describe the temporal precipitation characteristics of the region. The region is topographically complex as it neighbors both the Black Sea (to the $\mathrm{N}$ and NE) and the Aegean Sea (to the W and SW), features the Marmara Sea in the middle and is mountainous in parts, at least relative to, for example northwestern Europe. Therefore, CTs with southerly components that are associated with Mediterranean cyclonic activity bring the most precipitation to the western half; whereas the eastern half gets more precipitation originating from the Black Sea, as $\mathrm{CTs}$ with $\mathrm{N}$ and $\mathrm{E}$ components are the wettest here due to the sea-effect mechanism (see Baltac1 et al., [2015] for detailed discussion). Between 1971 and 2012, the mean annual value of regionally averaged amount of precipitation was $673 \mathrm{~mm}$ with no statistically significant trend through the period (Figure 4.1). Yet, there is a considerable inter-annual variability as characterized by a standard deviation of 190 $\mathrm{mm}$. For instance, 2010 was the wettest year with a mean annual precipitation of 994 $\mathrm{mm}$; when very intense rainfall (100-253 mm/day) in September caused 32 floodrelated casualties in Istanbul (Kömüşçü and Çelik, 2012). On the other hand, dry years such as 1989, 1993 and 2008 led to widespread water shortages. 


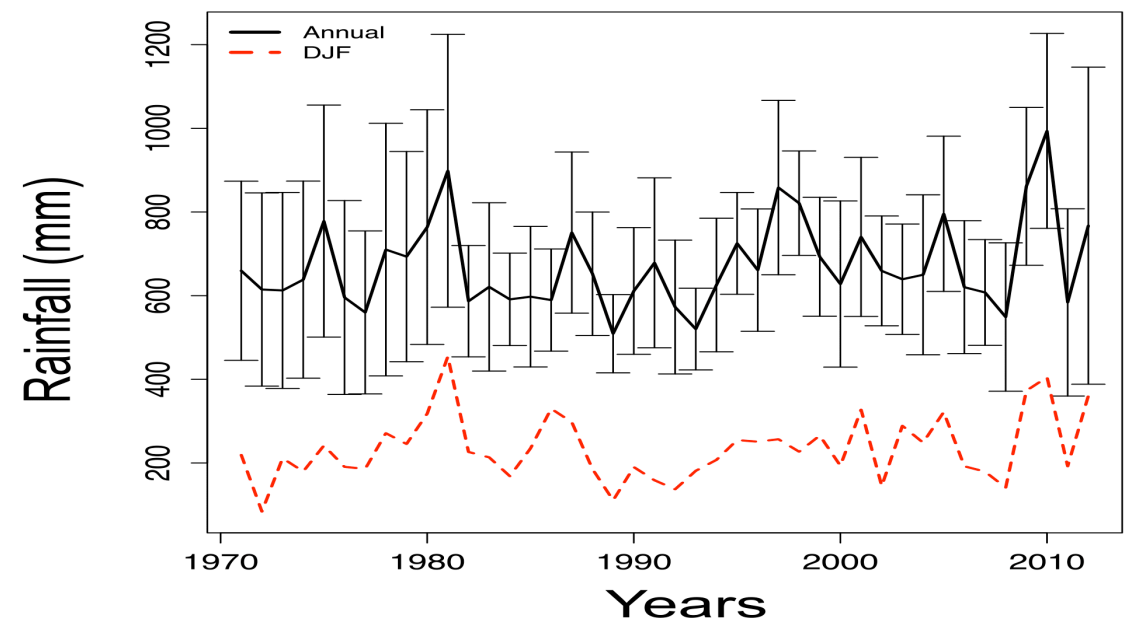

Figure 4.1 : Temporal annual (black) and winter (dashed) precipitation variability in Marmara based on the weighted averages of the 22 stations. Vertical lines indicate the standard deviation of the precipitation for each year.

\subsection{Trends and Moisture Flux Calculations}

\subsubsection{Sequential Mann-Kendall test}

This non-parametric rank-based test is widely used to identify the change of significance trend in time for climatological and hydrological studies. (e.g. Goossens and Berger, 1986; Karaca et al., 1995a; Tayanç et al., 1997; Partal et al., 2006; Ezber et al., 2007; Unal et al., 2012). Under the null hypothesis $\left(\mathrm{H}_{0}\right)$, test considers the relative values of all terms in the time series $\left(x_{1}, x_{2} \ldots, x_{n}\right)$. Later, $x_{j}$ elements, $(\mathrm{j}=1, \ldots \ldots, \mathrm{n})$ are compared with $\mathrm{x}_{\mathrm{k}},(\mathrm{k}=1, \ldots, \mathrm{j}-1)$. At each relation, the number of cases $\mathrm{x}_{\mathrm{j}}>\mathrm{x}_{\mathrm{k}}$ is counted and denoted by $\mathrm{n}_{\mathrm{j}}$. The test statistic $\mathrm{t}_{\mathrm{j}}$ is then given by the equation:

$$
t_{j}=\sum_{1}^{j} n_{j}
$$

The expected value and varience of $\mathrm{t} j$ are calculated as:

$$
E(t)=\frac{n(n-1)}{4} \text { and } \operatorname{var}\left(t_{j}\right)=\frac{[j(j-1)(2 j+5)]}{72}
$$

The reduced variables, called as statistic ${ }^{u(t)}$, are computed as follows:

$$
u(t)=\frac{t_{j}-E(t)}{\sqrt{\operatorname{Var}\left(t_{j}\right)}}
$$

The calculation of retrograde rows of statistic $u^{\prime}(t)$ is similar to the progressive rows of statistic $u(t)$ but is calculated backwards starting from the end of series. 
Intersection curves between $u(t)$ and $u^{\prime}(t)$ variables give us information about the developing trend within the time series. If one or two of the reduced variables are greater than the significance level, $\mathrm{H}_{0}$ can be ignored. The area above +1.96 and below -1.96 (from normal distribution table) represents the 95\% significance level.

\subsubsection{Influence of moisture flux}

Black Sea, Aegean Sea and Mediterranean Sea are the sources of moisture for Anatolian Peninsula. As a consequence of the increasing of SST in these seas, heat and moisture is transferred to the atmosphere. In order to understand the variability of daily SST under the each CTs and the NAO phases, daily winter mean SST values covering the period of 1982-2012 were obtained by NOAA high Resolution $\left(1 / 4^{\circ}\right)$ SST data (dashed red rectangle in Fig. 1.1b, provided by Url-2).

To investigate the moisture flux, source area was chosen covering the Anatolian Peninsula: $20^{\circ} \mathrm{W}-55^{\circ} \mathrm{E}$ longitudes and $25^{\circ} \mathrm{N}-65^{\circ} \mathrm{N}$ latitudes. For analyzing, NCEP/NCAR Reanalysis (Kalnay et al., 1996) data on $2.5^{\circ}$ grid resolution was used in the study for 42-yr period. The vertically integrated moisture flux was calculated from the following equations:

$$
\begin{aligned}
& Q_{v}=\frac{1}{g} \int_{p t}^{p o} q v d p \\
& Q_{u}=\frac{1}{g} \int_{p t}^{p o} q u d p
\end{aligned}
$$

Where $\mathrm{Q}_{\mathrm{v}}$ is the meridional moisture flux, $\mathrm{Q}_{\mathrm{u}}$ is the zonal moisture flux, $\mathrm{g}$ is the gravity, $\mathrm{q}$ is the specific humidity, $\mathrm{u}$ and $\mathrm{v}$ are the zonal and meridional components of the wind, and pt and po represent the pressure at $300-\mathrm{hPa}$ and the surface, respectively. Integrated vertical meridional moisture flux was calculated from $\mathrm{Q}_{\mathrm{v}}$ equation for each grid point (NCEP/NCAR) using finite differences from surface to the $300-\mathrm{hPa}$ (surface, 1000, 925, 850, 700, 600, 500, 400 and 300-hPa). 


\subsection{Trends in CT Frequencies}

Using the sequential Mann-Kendall test, we determined whether there is any trend in the occurrence frequencies of CTs affecting Marmara Region, between 1971 and 2012. All results are in Table 4.1, while Figure 4.2a-d shows the statistically significant trends, grouped by seasons. The most striking result obtained from this analysis is that; the pattern NE, which is on average the frequent of all CTs throughout the year (Baltac1 et al., 2015), exhibits a decreasing tendency of occurrence in all seasons, with the exception of MAM. This trend is especially strong in SON (Figure 4.2a), in which there seems to occur a regime shift after 1990s. Correspondingly, the opposite pattern SW shows statistically significant increasing trends in both SON and DJF (Figure 4.2a-b), the one in DJF being stronger.

Table 4.1 : Application of Mann-Kendall statistics to seasonal CTs occurring Marmara Region for the period 1971-2012 (95\% statistically significant numbers are marked bold).

\begin{tabular}{ccccc}
\hline \hline CTs & $\begin{array}{c}\text { Winter } \\
(\mathrm{DJF})\end{array}$ & $\begin{array}{c}\text { Spring } \\
(\mathrm{MAM})\end{array}$ & $\begin{array}{c}\text { Summer } \\
(\mathrm{JJA})\end{array}$ & $\begin{array}{c}\text { Fall } \\
(\mathrm{SON})\end{array}$ \\
\hline $\mathrm{N}$ & $\mathbf{- 2 . 3 1}$ & -0.13 & $\mathbf{- 2 . 4 1}$ & -1.66 \\
$\mathrm{NE}$ & $\mathbf{- 3 . 3 9}$ & -1.31 & $\mathbf{- 2 . 6 1}$ & $\mathbf{- 4 . 8 5}$ \\
$\mathrm{E}$ & 0.63 & 0.46 & $\mathbf{3 . 8 5}$ & 1.77 \\
$\mathrm{SE}$ & 1.78 & -0.10 & -0.30 & 1.80 \\
$\mathrm{~S}$ & 0.18 & $\mathbf{2 . 7 5}$ & 0.84 & 1.11 \\
$\mathrm{SW}$ & $\mathbf{2 . 6 1}$ & 0.32 & -0.44 & $\mathbf{2 . 0 4}$ \\
$\mathrm{W}$ & 0.01 & -0.02 & -0.77 & 0.81 \\
$\mathrm{NW}$ & -1.57 & -0.04 & -1.54 & -1.05 \\
$\mathrm{C}$ & -0.15 & $\mathbf{- 3 . 5 6}$ & -0.63 & -0.33 \\
$\mathrm{~A}$ & 1.74 & 0.70 & -0.28 & $\mathbf{2 . 4 1}$ \\
\hline
\end{tabular}

The apparent shift from NE to SW in fall and winter implies a notable alteration in the surface atmospheric circulation of east Europe and the Mediterranean basin for these seasons. The pattern SW belongs to the CTs of Category II (Baltac1 et al., 2015) featuring lower SLPs in central Europe and Italy; whereas for NE (belonging to the Category I), the SLP distribution is the exact opposite. Attributing temperature trends to these changes in the frequencies of individual CTs is not trivial, yet it is tempting to note that there is a regionally coherent, statistically significant increasing 
trend of SON temperatures in Marmara Region through the period 1971-2012. However, there is no such trend for DJF, when the shift from NE to SW can also be observed. The linkage of the above mentioned circulation changes to the larger scale, hemispheric circulation; as well as their significance in the precipitation variability of the region Marmara will be discussed in the subsequent sections.

In JJA, the decreasing trend of NE is compensated by an increase not in SW, but in $\mathrm{E}$ (Figure 4.2d). Both NE and E feature a high pressure in central and eastern Europe; and together they constitute the most dominant category of CTs affecting the area (Category I, 70\% in summer, Baltac1 et al., [2015]), therefore this change does not suggest a significant shift in the atmospheric circulation during JJA. Nevertheless, a shift from NE to $\mathrm{E}$ signifies an obvious reduction in the northerly component of surface winds. Thus, it might have contributed to the recent summertime temperature rise in Marmara together with the extending of Asiatic monsoon low to the central Anatolia (Türkeş and Tatl1, 2011).

Finally, a decreasing trend in the occurrence frequency of Cyclonic type $(\mathrm{C})$ is observed in MAM, during which type $\mathrm{S}$ in on the rise (Figure 4.2c). This is important, as $\mathrm{C}$ is the wettest pattern in MAM and $\mathrm{S}$ is the fourth driest of all ten types (Baltac1 et al., 2015). Possible continuation of these trends may mean drier springs in the future, especially for the western part of the region. 
(a)

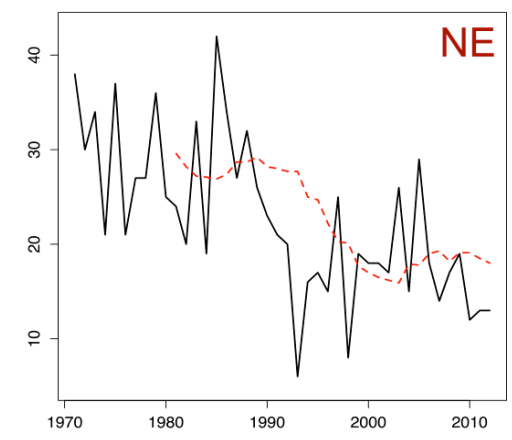

Fall (SON)

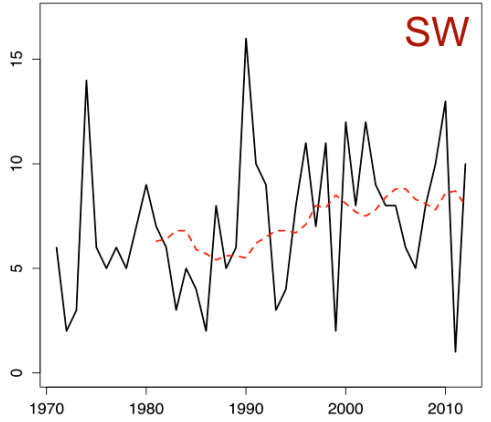

(b)

Winter (DJF)
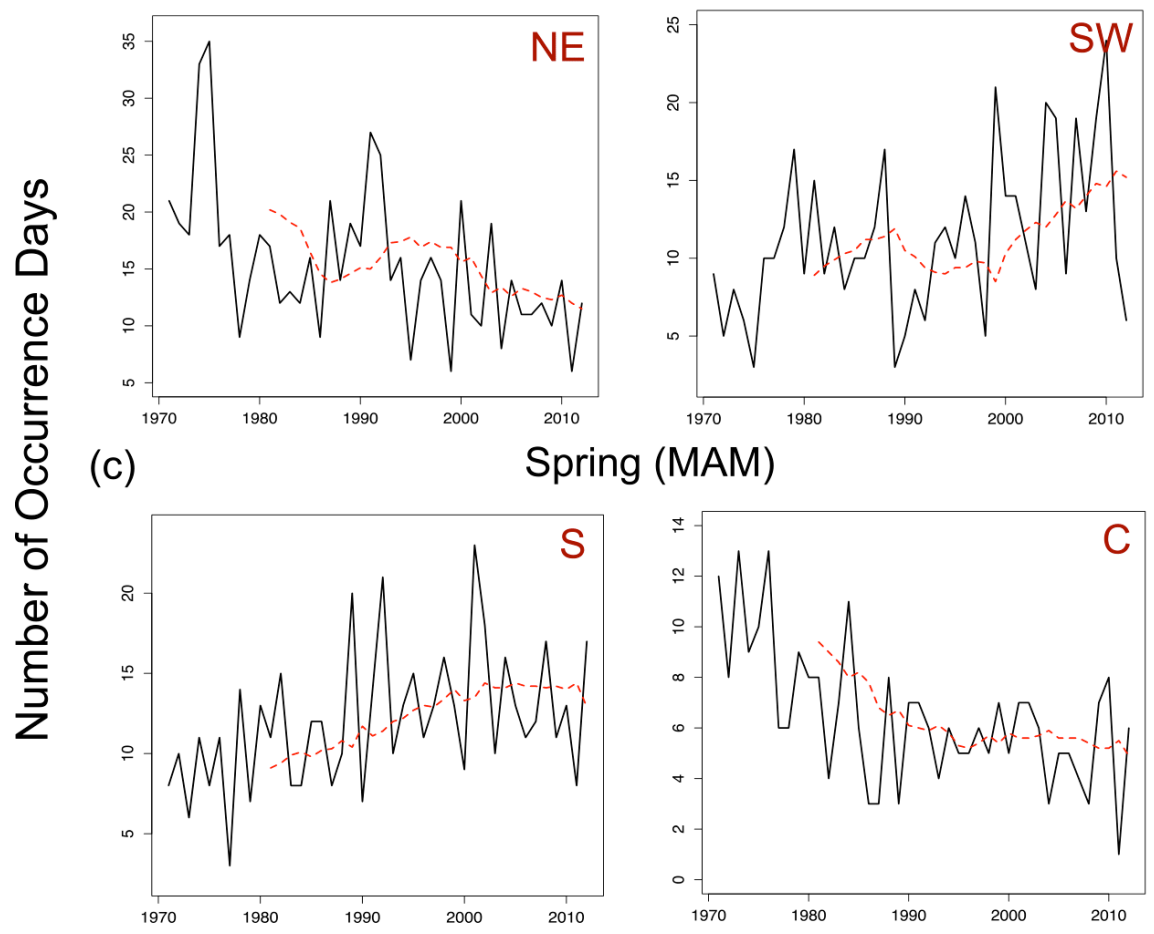

Spring (MAM)

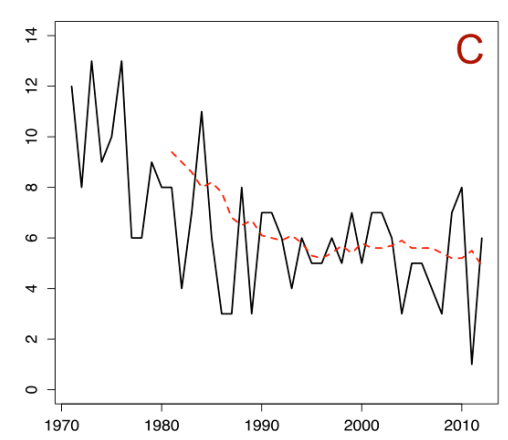

(d)

Summer (JJA)
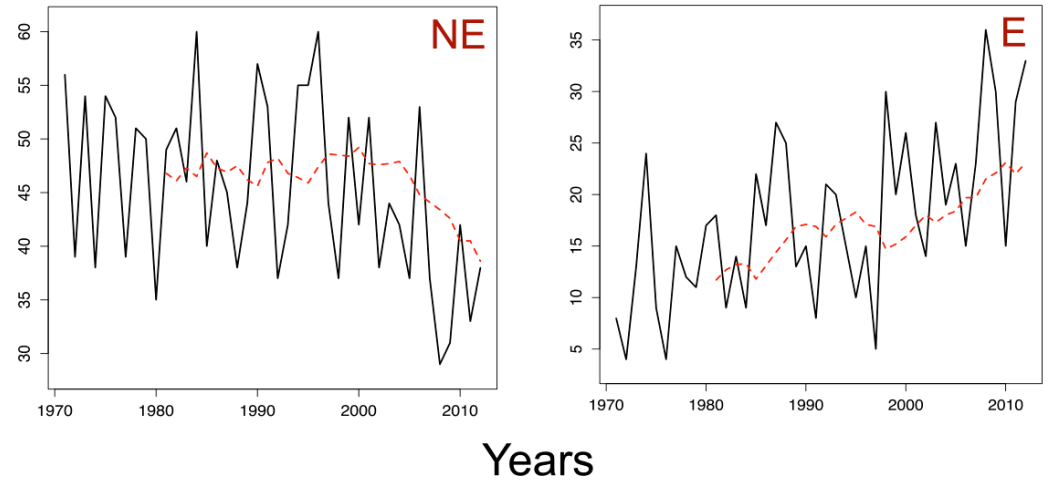

Figure 4.2 : Temporal evolution of selected CTs according to the $95 \%$ significance level (Table 4.1) during all seasons for the period 1971-2012. The dashed lines denote the 10-year moving average. 


\subsection{Trends in Precipitation Potentials of CTs}

In addition to determining how the occurrence frequencies of CTs changed in the period 1971-2012, we performed a trend analysis on the daily average precipitation values associated with each CT, for each season (Table 4.1). There are only four statistically significant trends in precipitation potentials, all of them in the direction of increasing: NE in SON and DJF; SE and SW in JJA. Of these, the ones for SE and $\mathrm{SW}$ in JJA can be neglected, as these CTs are the rarest in summer (1\% frequency each). However, the increasing precipitation potential of NE in SON and DJF is noteworthy. NE is the most frequent $\mathrm{CT}$ in SON and the second most frequent in DJF on average; though it is becoming less frequent in both seasons (Fig. 4.2a-b). Obviously, the decreasing frequency of occurrence (hence, precipitation contribution) of $\mathrm{NE}$ is compensated by its increasing intensity of rainfall. This also means a decreasing number of wet days with more intense rain, especially for the northeastern section of the region, including Istanbul, where NE is the wettest $\mathrm{CT}$ in DJF and one of the wettest in SON (Baltac1 et al., 2015). The reasons for these changes in the occurrence and precipitation characteristics of the pattern NE will be further elaborated on, in relation with teleconnection patterns.

\subsection{Temporal Behavior of Winter (DJF) Rainfall during NE Cases: Moisture Flux Transport Mechanism}

Owing to the sensitivity of the metropolitan cities on daily rainfall basis, temporal variability of daily precipitation has a critical importance. For this reason, we applied trend analysis to the daily precipitation record for the different CTs. According to Table 4.2, statistically significant increasing trend in rainfall is shown during NE (DJF and SON), SE and SW (JJA) types. We do not analyze in detail SE and SW types because of the least frequent of these types in JJA. During NE cases in DJF, continuous increasing rainfall trend starts at the beginning of the 2000s (10-yr moving average in Fig. 4.3), and highest daily precipitation reached to $10 \mathrm{~mm}$ at 2010 year (16 mm, in the east stations such as Kireçburnu, Kocaeli and Sakarya). In this type, although the numbers of NE (Fig. 4.2b) decrease with time, increasing rainfall intensity trend is shown in Marmara. If this position maintains in the next years, many flash floods can be observed in the urban settlements. Therefore, 
possible reasons of this intensity increment should be explained more detail for the region.

Table 4.2 : Application of Mann-Kendall statistics to the seasonal daily precipitation $\left(\mathrm{mm} \mathrm{day}^{-1}\right) .(95 \%$ statistically significant numbers are marked bold).

\begin{tabular}{lcccc}
\hline \hline CTs & Winter (DJF) & Spring (MAM) & Summer (JJA) & Fall (SON) \\
\hline N & 0.62 & 0.65 & -1.27 & 1.37 \\
NE & $\mathbf{3 . 3 2}$ & 1.04 & -0.48 & $\mathbf{3 . 6 8}$ \\
E & 1.65 & 0.70 & -0.41 & 0.86 \\
SE & 1.27 & -0.96 & $\mathbf{3 . 9 7}$ & 1.13 \\
S & 0.40 & -0.16 & -0.39 & -1.34 \\
SW & 0.79 & 1.00 & $\mathbf{2 . 5 3}$ & -0.01 \\
W & 0.28 & 0.23 & 0.52 & 1.45 \\
NW & 1.53 & -0.47 & 0.46 & 1.62 \\
C & 1.14 & -0.15 & -0.35 & 1.19 \\
A & 0.37 & 0.91 & 1.05 & 0.67 \\
\hline
\end{tabular}

Parallel to the researches related to climate change, sea surface temperature studies were explained to understand the variability of SST and its impact on ecosystems. During the last century, global mean sea surface temperature increased by $0.67{ }^{\circ} \mathrm{C}$ (Trenberth et al., 2007). Belkin (2009) presents most rapid warming was observed in the land-locked or semi-enclosed European and East Asian Seas (e.g. Baltic Sea, Black Sea, North Sea). For our region, numerous studies have been focused on the relationship between SST values of Black Sea (BS) and their impact on precipitation mechanism. Kindap (2010) explained sea-effect snowfall mechanism formed over Black Sea using the synoptic conditions, vertical wind shear and strong northerly winds, SST- $850 \mathrm{hPa}$ and SST-land temperature differences. Bozkurt and Şen (2011) stated that 2-K increases of the SSTs of the Black Sea (using a state-of-the-art regional climate model, RegCM3), enhances the region of Marmara (except Trakya, NW Marmara) precipitation in all seasons. Ufuk (2014), by utilizing state-of-the-art remote sensing products, hypothesized that statistically significant positive correlation between SST of the Western BS and the precipitation was found in the Northeast stations of the region during winter and fall months. Baltac1 et al., (2015) stated that, during NE days, monthly average SST-850 hPa temperature difference is strongly correlated to precipitation for the eastern stations. 


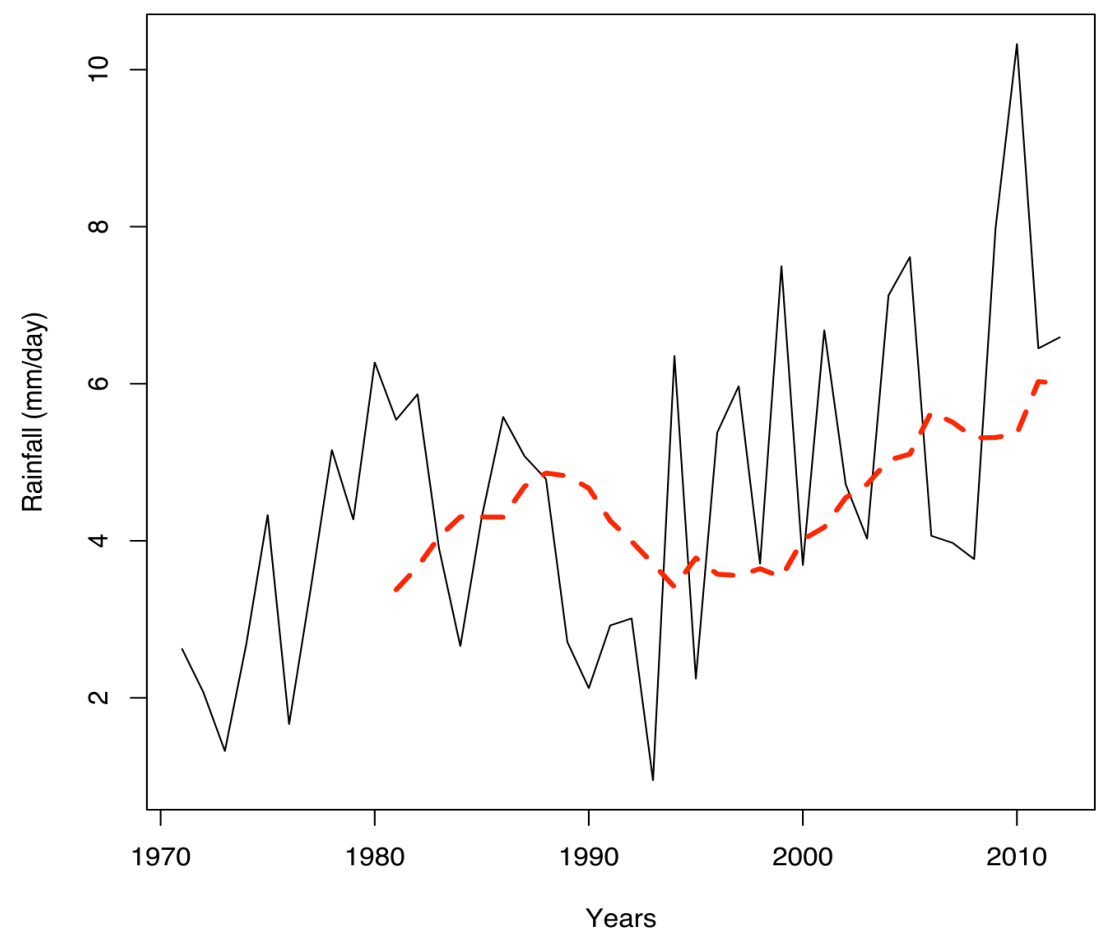

Figure 4.3 : Temporal distribution of regional daily rainfall $\left(\mathrm{mm} \mathrm{day}^{-1}\right)$ in active winter-NE times for the period 1971-2012.

Differently from the previous studies summarized above, we analyzed the potential causes of the daily rainfall intensity differences realized during NE cases in winter (depending on the inverse relation in the numbers and daily rainfall totals). For this purpose, large-scale moisture transport and its relation to rainfall were investigated for our region. In literature, many studies have emphasized the moisture flux-rainfall assessments (Mo and Higgins, 1996; Simmonds et al., 1999; Soares and Marengo, 2008; Arraut and Nobre, 2012). In our research, we divided daily rainfall into the five categories according to the magnitude for winter (Table 4.3): no rain, light rain, moderate, intense and very intense (Osborn et al., 2000; Osborn and Hulme, 2002; Gallego et al., 2006).

Table 4.3 : Categories of daily precipitation (PRCP) for winter.

\begin{tabular}{ccccc}
\hline \hline Period & Light & Moderate & Intense & Very Intense \\
\hline Winter & $0 \mathrm{~mm}<\mathrm{PRCP}<3$ & $3 \mathrm{~mm}<\mathrm{PRCP}<9$ & 9 & PRCP $>21$ \\
\hline
\end{tabular}

For analyzing, we presented two sub-groups for daily rainfall: below $3 \mathrm{~mm}$ (light rains and no rain categories) and above $9 \mathrm{~mm}$ (intense and very intense conditions). Subsequently, the composite maps of these two sub-groups were extracted from the 
NCEP/NCAR Reanalysis products. Figure 4.4 shows the average daily MSLP, integrated vertical meridional moisture flux from surface to $300-\mathrm{hPa}$ together with $850-\mathrm{hPa}$ wind vectors.

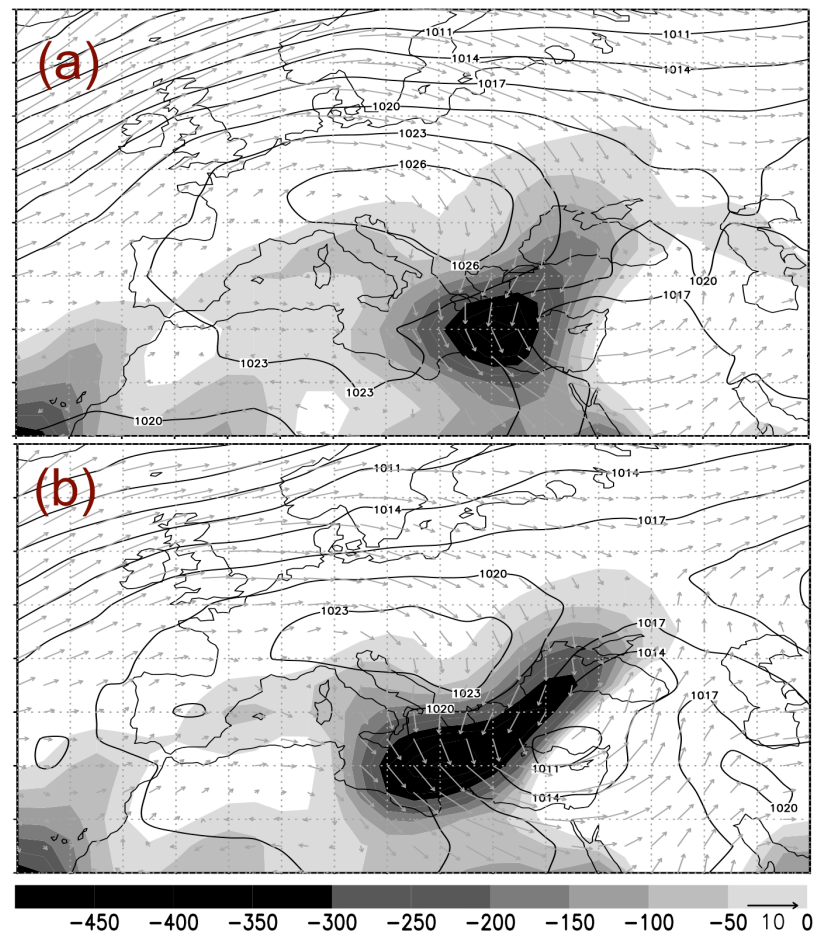

Figure 4.4 : Composite maps of synoptic conditions, moisture flux and $850 \mathrm{hPa}$ winds $\left(\mathrm{m} \mathrm{s}^{-1}\right)$ based on the light (a) and intense daily rainfall magnitudes (b) during winter-NE times. Colour values indicate the integrated meridional moisture flux $\left(\mathrm{kgm}^{-1} \mathrm{~s}^{-1}\right)$.

In light rain conditions (320 days, (Fig. 4.4a), mean SST is measured $0.3^{\circ} \mathrm{C}$ below the average value $\left(8.1^{\circ} \mathrm{C}\right)$, due to of the location of high pressure center over the Eastern Europe (1026-hPa), existing moisture in the atmosphere is transferred to Marmara from Black Sea owing to meridional flows. In tropospheric vertically integrated meridional flux is recorded between $100-150 \mathrm{kgm}^{-1} \mathrm{~s}^{-1}$ in the NW parts and $150-200 \mathrm{kgm}^{-1} \mathrm{~s}^{-1}$ in the other locations of the region. Most remarkable moisture fluxes $\left(>300 \mathrm{kgm}^{-1} \mathrm{~s}^{-1}\right)$ are shown in the Eastern Mediterranean Basin. Northerly 850$\mathrm{hPa}$ winds reaches $10 \mathrm{~m} / \mathrm{s}$ in the south part of the region. Highly positively correlation of EAWR with NE frequencies, markedly determines light rainfall conditions instead of the SST variability of Black Sea, In terms of NAO, only the index values ( $>0)$ are represent $68 \%$ of all light rains. 
During the intense daily rainfall conditions (Fig. 4.4b), in addition to the similar location of high-pressure centre over Eastern Europe, the core of the low-pressure centre positioned over Cyprus extends along central Anatolia. As a result of the higher SST values $\left(0.6^{\circ} \mathrm{C}\right.$ above than average, not shown), more heat and humidity are transferred to the atmosphere. Afterwards, moisture was transported from Black Sea (long enough fetch distance) to the Marmara by strong northerly winds. Vertically integrated meridional moisture flux values are measured between 250 and $300 \mathrm{kgm}^{-1} \mathrm{~s}^{-1}$ in Thrace, and above $300 \mathrm{kgm}^{-1} \mathrm{~s}^{-1}$ in the other parts of the region.

For a synoptic-scale perspective, when we consider the main differences of the winter rainfalls during 2010 (major rainiest year, Fig. 4.1b) than the other winters, it can be seen an increment (decrement) of SW (NE) as well as higher SST values over Black Sea in the region together with the more cyclones located over Cyprus.

\subsection{Association with Teleconnection Patterns}

In order to assess the connection of CTs in Marmara Region to the variations in larger scale circulation; we calculated the correlations between the seasonal occurrence frequencies of each $\mathrm{CT}$ and the indices of five teleconnection patterns which are known to influence the Northern Hemisphere climate. Table 4.4 and Fig. 4.5 show the correlation values. DJF is when the highest number of significant correlations occur (Fig. 4.5), as the role of teleconnection patterns in determining the atmospheric circulation in Turkey and the entire eastern Mediterranean is the greatest in this season. EA/WR is the most influential pattern in the occurrence of CTs during winter (Fig. 4.5a), exhibiting positive significant (at 99\% level) correlations with NE and NW; and negative ones with SW and C. The strongest association of EA/WR is with NE and SW in opposite directions, the negative correlation value with SW reaching as high as 0.48 (Table 4.4). The increasing (decreasing) frequency of SW (NE) through the period $1971-2012$ is, however, not accompanied with a significant decrease in the EA/WR index values within the same period. The second most influential teleconnection pattern on the CTs of Marmara Region during DJF is the $\mathrm{AO}$, whose relationship with the occurrence of $\mathrm{NE}, \mathrm{SW}$ and $\mathrm{C}$ is in the same fashion with EA/WR; though the correlation values are lower for NE and SW (Fig. 4.5a). 
Table 4.4 : Correlations between TPs and the frequency of CTs for each season. (99\% statistically numbers are marked bold).

\begin{tabular}{lcccccccccc}
\hline \hline Winter & $\mathrm{N}$ & $\mathrm{NE}$ & $\mathrm{E}$ & $\mathrm{SE}$ & $\mathrm{S}$ & $\mathrm{SW}$ & $\mathrm{W}$ & $\mathrm{NW}$ & $\mathrm{C}$ & $\mathrm{A}$ \\
\hline NAO & 0.08 & 0.14 & 0.06 & -0.11 & -0.06 & -0.18 & -0.10 & 0.10 & $\mathbf{- 0 . 3 0}$ & 0.17 \\
EA & -0.12 & -0.19 & 0.08 & -0.06 & 0.21 & 0.03 & -0.17 & -0.15 & -0.00 & 0.19 \\
EA/WR & 0.17 & $\mathbf{0 . 4 3}$ & 0.18 & -0.06 & -0.12 & $\mathbf{- 0 . 4 8}$ & -0.17 & $\mathbf{0 . 2 4}$ & $\mathbf{- 0 . 2 8}$ & 0.05 \\
SCA & $\mathbf{- 0 . 3 0}$ & 0.11 & 0.18 & 0.22 & 0.12 & -0.07 & 0.11 & -0.23 & -0.04 & $\mathbf{- 0 . 3 6}$ \\
AO & 0.09 & $\mathbf{0 . 2 6}$ & 0.15 & -0.16 & -0.11 & $\mathbf{- 0 . 2 9}$ & -0.12 & 0.10 & $\mathbf{- 0 . 3 4}$ & 0.18 \\
\hline Spring & $\mathrm{N}$ & $\mathrm{NE}$ & $\mathrm{E}$ & $\mathrm{SE}$ & $\mathrm{S}$ & $\mathrm{SW}$ & $\mathrm{W}$ & $\mathrm{NW}$ & $\mathrm{C}$ & $\mathrm{A}$ \\
\hline NAO & -0.14 & 0.22 & 0.18 & -0.09 & 0.11 & -0.12 & $\mathbf{- 0 . 2 4}$ & -0.06 & -0.10 & -0.17 \\
EA & -0.08 & 0.01 & 0.18 & -0.14 & 0.18 & -0.02 & -0.17 & -0.18 & -0.07 & -0.04 \\
EA/WR & -0.05 & 0.21 & 0.12 & -0.02 & 0.08 & $\mathbf{- 0 . 2 3}$ & -0.06 & -0.04 & -0.13 & 0.07 \\
SCA & $\mathbf{- 0 . 3 2}$ & 0.15 & 0.14 & 0.13 & -0.08 & -0.07 & -0.19 & -0.19 & 0.17 & 0.00 \\
AO & 0.07 & 0.02 & 0.21 & -0.08 & 0.09 & -0.15 & -0.07 & 0.05 & -0.09 & -0.09 \\
\hline Summer & $\mathrm{N}$ & $\mathrm{NE}$ & $\mathrm{E}$ & $\mathrm{SE}$ & $\mathrm{S}$ & $\mathrm{SW}$ & $\mathrm{W}$ & $\mathrm{NW}$ & $\mathrm{C}$ & $\mathrm{A}$ \\
\hline NAO & 0.16 & $\mathbf{0 . 2 8}$ & $\mathbf{- 0 . 3 2}$ & -0.03 & -0.14 & -0.01 & 0.14 & 0.04 & -0.05 & -0.19 \\
EA & -0.19 & -0.19 & $\mathbf{0 . 3 2}$ & 0.06 & 0.17 & -0.13 & -0.11 & -0.17 & 0.01 & -0.12 \\
EA/WR & -0.16 & 0.14 & -0.02 & -0.05 & 0.00 & 0.00 & -0.12 & -0.06 & -0.09 & 0.16 \\
SCA & $\mathbf{0 . 3 6}$ & -0.13 & $\mathbf{- 0 . 3 5}$ & -0.00 & -0.00 & 0.07 & $\mathbf{0 . 2 4}$ & 0.23 & 0.22 & 0.21 \\
AO & -0.01 & $\mathbf{0 . 2 4}$ & -0.10 & -0.07 & -0.09 & -0.05 & 0.02 & -0.06 & -0.16 & $\mathbf{- 0 . 2 5}$ \\
\hline Fall & $\mathrm{N}$ & $\mathrm{NE}$ & $\mathrm{E}$ & $\mathrm{SE}$ & $\mathrm{S}$ & $\mathrm{SW}$ & $\mathrm{W}$ & $\mathrm{NW}$ & $\mathrm{C}$ & $\mathrm{A}$ \\
\hline NAO & -0.05 & $\mathbf{0 . 2 6}$ & $\mathbf{0 . 2 4}$ & -0.00 & -0.12 & $\mathbf{- 0 . 3 0}$ & -0.14 & -0.02 & -0.15 & -0.12 \\
EA & $\mathbf{- 0 . 3 3}$ & 0.02 & $\mathbf{0 . 2 7}$ & -0.03 & -0.09 & -0.07 & -0.16 & -0.16 & -0.12 & 0.02 \\
EA/WR & -0.06 & 0.13 & 0.08 & -0.01 & -0.00 & $\mathbf{- 0 . 2 3}$ & 0.04 & 0.01 & -0.03 & -0.01 \\
SCA & -0.06 & -0.19 & 0.11 & 0.18 & -0.04 & 0.05 & 0.08 & -0.13 & 0.22 & -0.00 \\
AO & -0.08 & $\mathbf{0 . 2 8}$ & $\mathbf{0 . 3 0}$ & -0.16 & -0.18 & -0.18 & -0.22 & -0.09 & -0.22 & -0.10 \\
& & & & & & & & & & \\
\hline & & & & & & & & & &
\end{tabular}

Surprisingly, the NAO, whose wintertime impact on Turkey is the most studied and documented among all teleconnection patterns; has generally weak and insignificant influence on the occurrence of CTs in Marmara Region in DJF. An exception is the Cyclonic pattern, which is already known and shown here as well to occur more frequently in winter during the negative mode of the NAO (Fig. 4.5a). As the relationship of teleconnection patterns with CTs become less obvious in other seasons (Fig. 4.5b-d), the NAO becomes relatively more influential. For instance, the NE-SW alternation seems to be controlled more by NAO during SON than by EA/WR or AO (Fig. 4.5d), though the highest correlations with the NAO are much smaller than those (of EA/WR) for DJF. Likewise, the NAO has a clear influence in JJA on the alternating occurrence of NE and E (Fig. 4.5c), which dominate this season with a mean occurrence frequency of $70 \%$ in aggregate. The decreasing trend of summer NAO index within the period 1971-2012 can explain the decreasing (increasing) occurrence of NE (E) (Fig. 4.2d) in JJA, which is further amplified by an 
increase in the summer EA pattern index. Possible continuation of these trends might well lead to drier summers in the region, as E is the driest $\mathrm{CT}$ in this season with a regional rainfall average equaling to one sixth of that of NE (Baltac1 et al., 2015).

(a)

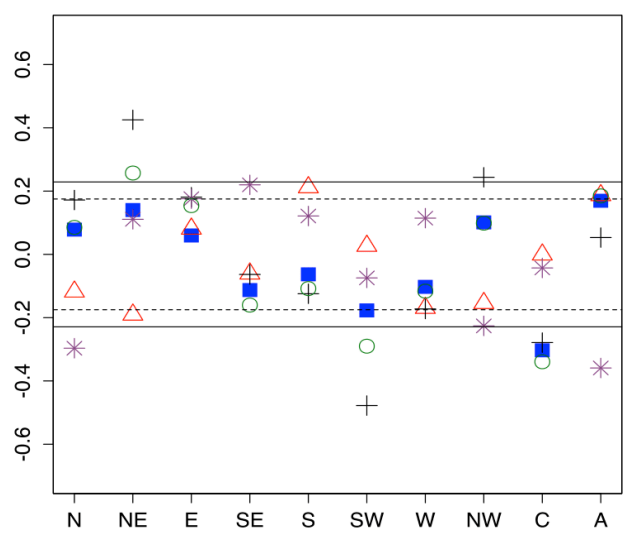

(c)

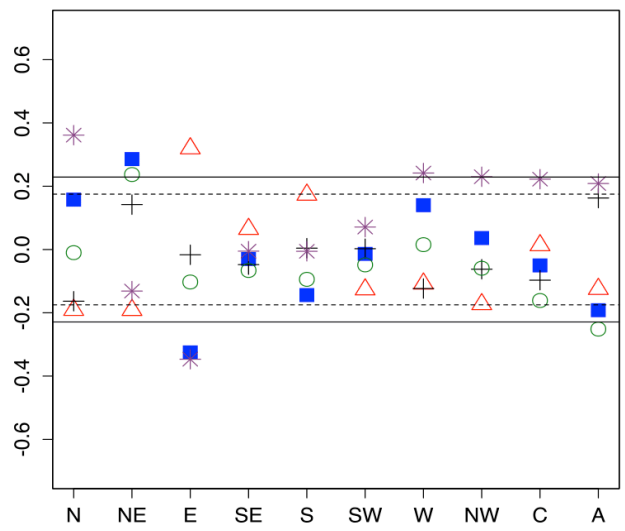

(b) Spring (MAM)

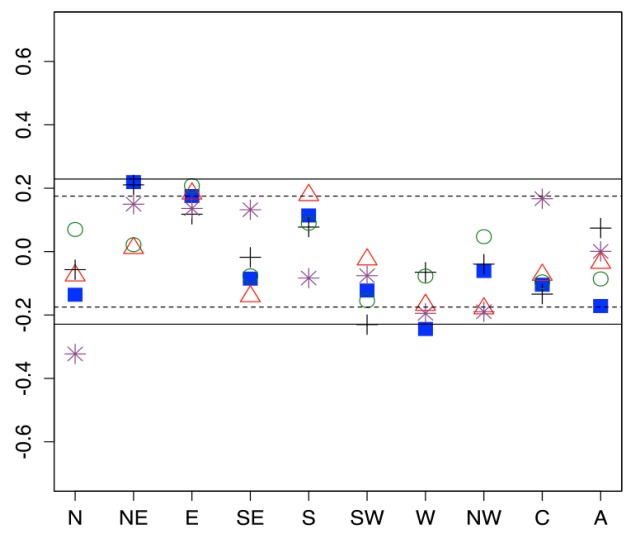

Fall (SON)

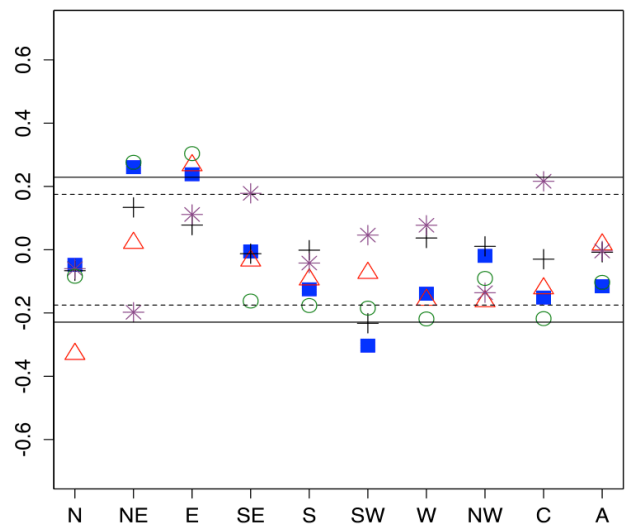

Figure 4.5 : Correlation between different teleconnection patterns (NAO(square)), EA (triangle), EA/WR (plus), SCA (star) and AO is shown as circles) and the frequency of atmospheric circulation patterns for the different seasons. Solid and dashed horizontal lines express $99 \%$ and $95 \%$ statistically significance level, respectively. 


\section{THE INFLUENCE OF ATMOSPHERIC CTS ON REGIONAL PATTERNS OF PRECIPITATION IN MARMARA}

\subsection{Regional Patterns of Precipitation in Marmara}

Numerous studies have endeavored to classify climate zones and atmospheric CTs of Turkey and its regions. In terms of climate zones, Erinç (1984) qualitatively described seven climate regions by taking into account climatic differences and the changes in the social and economic properties of the country, which are still used for describing the classifications of climate regions. Türkeş (1996) quantitatively characterized climate zones by applying a coefficient of variations to the two primary climatological variables (i.e. temperature and precipitation). Subsequently, Ünal and colleagues (2003) investigated the climate regions of Turkey by using hierarchical clustering techniques. They first compared five cluster methods, including single, complete, centroid and average linkage as well as Ward's methodologies. They found that Ward's method gave better results, and found seven different climate zones and six precipitation regions. Türkeş and Tatli (2011) identified eight consistent precipitation regime regions for the Anatolian Peninsula using spectral clustering for investigating atmospheric and geographical controls.

Sönmez and Kömüşcü (2011) reclassified the rainfall regions of Turkey by using non-hierarchical K-means methodology and the relationship between drier or wetter periods and the North Atlantic Oscillation (NAO). They found six rainfall clusters, which included Aegean and Marmara region in the same cluster, and determined that temporally dry periods are partially explained by NAO. Differently from previous studies, Sahin and Cigizoglu (2012), using the Ward's and neuro-fuzzy method, investigated the sub-climate and sub-regional precipitation characteristics as well as main climate and precipitation regions together with the physical properties of the regions. According to the results, Turkey is composed of seven main precipitation climates and 16 sub-regional precipitation climates. 
Some of the previous cluster analysis solutions revealed that the Marmara and Aegean regions have the same precipitation climate and are likely to be one cluster. However, besides highly spatial and temporal rainfall variability between these two regions, the spatial distribution of precipitation characteristics of Marmara shows different behavior. Non-uniform spatial and temporal distribution of the rainfall in Marmara and its sub-basins, which is the most populated region and the economic powerhouse of Turkey, influences the infrastructure (e.g. flash floods), limited or unrestricted fresh water storage in water basins, and the socioeconomic development of the region and country. Therefore, more comprehensive studies for understanding the regional patterns of precipitation in Marmara are required, and should also consider its synoptic perspectives.

In this part of the study, we preferred Ward's methodology for detecting sub-regional precipitation of Marmara, as it is both widely used and is actually the most suitable method (Ünal et al., 2003) for describing the climate regions of Turkey. Therefore, winter precipitation records of 19 meteorological stations (except Balıkesir, Bilecik, and Bozuyuk stations in Figure 2.2, due to insufficient long-term data) in Marmara were studied for the period 1960-2012. To standardize the winter precipitation values based on 19 meteorological stations, zero mean and unit variance were used. The dissimilarity was measured by Euclidean distance. As a result of the clustering solutions, five clusters were considered sufficient for our region, even though the objective method for identifying the number of clusters to be retained was not universally accepted (Figure 5.1 and Table 5.1).

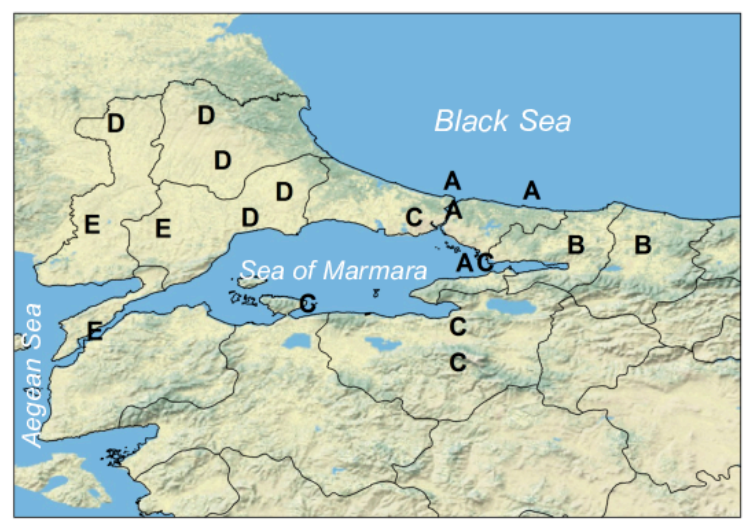

Figure 5.1 : The five clusters of the Marmara region according to Ward's method. The cluster letters are explained in Table 5.1. 
Table 5.1 : The five-cluster solution of Ward's method between cluster algorithm.

\begin{tabular}{|c|c|c|}
\hline Cluster letter & No. of stations and their names & Definition \\
\hline A & $\begin{array}{l}4 \text { (Kirecburnu, Kumköy, Şile, and } \\
\text { Çinarcık) }\end{array}$ & $\begin{array}{l}\text { The Marmara and Black Sea } \\
\text { region }\end{array}$ \\
\hline B & 2 (Kocaeli and Sakarya) & The Black Sea region \\
\hline $\mathrm{C}$ & $\begin{array}{l}5 \text { ( Bursa, Yalova, Keles, } \\
\text { Bandırma, and Florya) }\end{array}$ & The Marmara region \\
\hline $\mathrm{D}$ & $\begin{array}{l}5 \text { (Edirne, Kurklareli, Lüleburgaz, } \\
\text { Corlu, and Tekirdağ) }\end{array}$ & The Thrace region \\
\hline E & 3 (Çanakkale, İpsala, and Malkara) & The Aegean region \\
\hline
\end{tabular}

Later, to obtain statistical information for each rainfall cluster, a box-whisker plot of the clusters was devised (Figure 5.2), where the central mark on each box is the median, the edges of the box are the 25th and 75th percentiles, and the dashed lines extending to the most extreme data are the whiskers. For each box, the outliers and the means are plotted with "o" and "+" symbols, respectively. Cluster A includes four stations and shows similar characteristics to the Black Sea and Marmara Sea regions. This sub-region has the highest average DJF rainfall (308 mm). Maximum DJF precipitation occurred during 1981 with $780 \mathrm{~mm}$. In cluster B, two stations indicate Black Sea region rainfall properties; the winter rainfall average increased to $277 \mathrm{~mm}$. For cluster C, four of five stations are located close to the Sea of Marmara and present a typical Marmara precipitation climate (Figure 5.1). The second highest winter precipitation is observed in this cluster with $282 \mathrm{~mm}$ (Figure 5.2). In terms of cluster D, five land-based stations located NW of Marmara have the lowest winter average precipitation total of $193 \mathrm{~mm}$ (Figures 5.1 and 5.2). This sub-region is known as the Thrace basin and has great importance in terms of agricultural production (e.g. rice and sunflowers). Three stations in the west part of the Marmara region are separated from the Thrace basin and typically present an Aegean rainfall climate. In this cluster, E, the average winter precipitation is $257 \mathrm{~mm}$. 


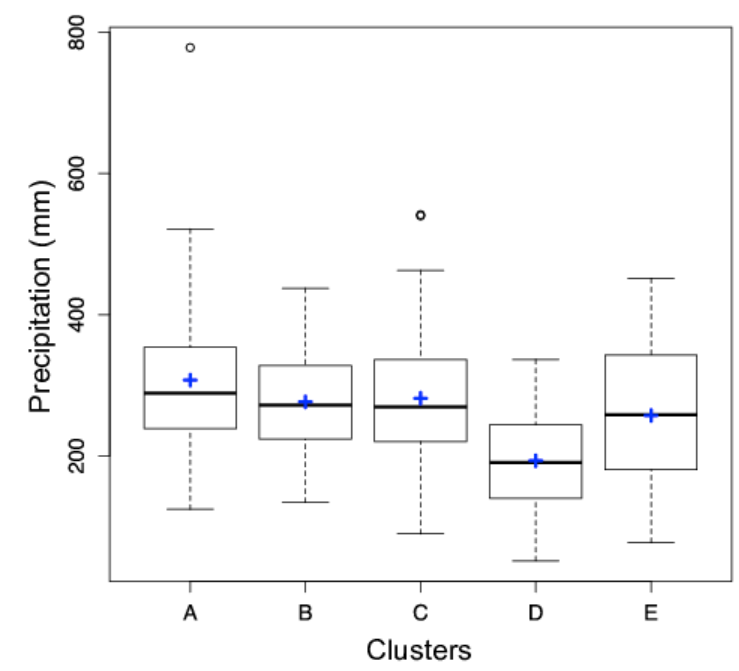

Figure 5.2 : Box-plot of the Ward's method clusters for the 1960-2012 period. The cluster letters are explained in Table 5.1.

\subsection{Atmospheric Circulation Classifications}

The most frequent atmospheric CTs were investigated for the Marmara region. As shown in Table 5.2, 93\% of the winter mean frequencies of CTs relate to the eight directional and two vorticity types (C and $\mathrm{A})$. For this reason, the long-term winter composites of 10 CTs (out of 27) were taken into account (Figure 5.3). Despite the low frequency of northerly types $(\mathrm{N})$, maximum daily precipitation amounts are recorded in the $\mathrm{A}, \mathrm{B}$ and $\mathrm{C}$ clusters. This $\mathrm{N}$ type is the second wettest type after cyclonic (C) patterns for $\mathrm{D}$ and $\mathrm{E}$ sub-regions (Table 5.2) because there is no humidity transfer for the $\mathrm{D}$ and $\mathrm{E}$ regions (Figure 5.3).

Table 5.2 : Winter (DJF) mean frequencies of CTs and their contribution to the daily mean precipitation amounts $\left(\mathrm{mm} \mathrm{day}^{-1}\right)$ and to total precipitation $(\%)$ for the defined five clusters during the period 1960-2012.

\begin{tabular}{cccccccccccc}
\hline \hline $\mathrm{CT}$ & $\%$ & \multicolumn{1}{c}{$\mathrm{A}$} & \multicolumn{3}{c}{$\mathrm{B}$} & \multicolumn{2}{c}{$\mathrm{C}$} & \multicolumn{3}{c}{$\mathrm{D}$} & \multicolumn{3}{c}{$\mathrm{E}$} \\
\hline & & $\mathrm{mm} / \mathrm{d}$ & $\%$ & $\mathrm{~mm} / \mathrm{d}$ & $\%$ & $\mathrm{~mm} / \mathrm{d}$ & $\%$ & $\mathrm{~mm} / \mathrm{d}$ & $\%$ & $\mathrm{~mm} / \mathrm{d}$ & $\%$ \\
$\mathrm{~N}$ & 1.63 & 11.49 & 5.50 & 11.47 & 6.10 & 11.84 & 6.19 & 5.13 & 3.91 & 5.83 & 3.33 \\
$\mathrm{NE}$ & 14.2 & 6.68 & 28.0 & 7.46 & 34.7 & 5.84 & 26.7 & 2.17 & 14.4 & 2.81 & 14.0 \\
$\mathrm{E}$ & 29.5 & 3.26 & 28.2 & 2.75 & 26.5 & 2.48 & 23.4 & 1.43 & 19.7 & 2.27 & 23.6 \\
$\mathrm{SE}$ & 3.91 & 1.55 & 1.78 & 0.97 & 1.23 & 1.38 & 1.73 & 1.79 & 3.27 & 3.00 & 4.12 \\
$\mathrm{~S}$ & 3.30 & 1.78 & 1.73 & 1.53 & 1.65 & 1.86 & 1.97 & 2.02 & 3.11 & 2.69 & 3.11 \\
$\mathrm{~S}$ & 9.99 & 1.08 & 3.17 & 0.71 & 2.33 & 1.25 & 4.00 & 2.11 & 9.85 & 3.08 & 10.7 \\
$\mathrm{~W}$ & 13.6 & 2.22 & 8.91 & 1.82 & 8.13 & 2.43 & 10.6 & 2.18 & 13.9 & 2.35 & 11.3 \\
$\mathrm{~N}$ & 1.86 & 6.39 & 3.49 & 4.78 & 2.90 & 6.84 & 4.08 & 5.06 & 4.40 & 5.24 & 3.42 \\
$\mathrm{C}$ & 4.58 & 6.83 & 9.18 & 4.18 & 6.24 & 7.18 & 10.5 & 7.18 & 15.3 & 9.34 & 14.9 \\
$\mathrm{~A}$ & 8.13 & 1.26 & 3.01 & 1.48 & 3.92 & 1.12 & 2.93 & 0.46 & 1.74 & 0.54 & 1.55 \\
\hline
\end{tabular}


The rainfall contribution to the winter total is between $5 \%$ and $7 \%$ for the eastern parts of the region ( $\mathrm{A}, \mathrm{B}$, and $\mathrm{C})$, but the ratio decreases $3 \%$ in the cluster $\mathrm{E}$ subbasin. In northeasterly (NE) cases (the second most frequent CT over Marmara), the maximum daily precipitation values are observed close to the Black Sea stations (cluster B), followed by clusters $\mathrm{A}$ and $\mathrm{C}$ with values of $6.68 \mathrm{~mm} /$ day and 5.84 $\mathrm{mm} /$ day, respectively. Percentage contribution to the winter rainfall of NE types are $34.74 \%, 28.02 \%, 26.71 \%, 14.47 \%$, and $14.09 \%$ in $\mathrm{B}, \mathrm{A}, \mathrm{C}, \mathrm{D}$, and $\mathrm{E}$ sub-regions, respectively. In this type, the region is under the influence of a high-pressure centre (HPC) located over eastern Europe and a low-pressure centre (LPC) located over Cyprus; hence, NE types bring humidity from the semi-closed water body called the Black Sea (Figure 5.3). In the most frequent CTs (easterly (E) types), although the sub-regions have low daily precipitation values, the percentage addition to winter rainfall total changes from $19.75 \%$ to $28.28 \%$ for the D and A clusters, respectively. The position of HPC over the Balkan Peninsula and clockwise rotation result in easterly patterns in Marmara (Figure 5.3). The flows move over Marmara and more winter rainfall records are observed in the Thrace basin and the Aegean region (clusters $\mathrm{D}$ and $\mathrm{E}$ in Table 5.2). Both the daily rainfall intensity and the average number of rainfalls decrease during the active southeasterly (SE) and southerly (S) patterns (Table 5.2). In these cases, as a consequence of the Genoa LPC and HPC over the north of the Caspian Sea, the flows move throughout the eastern Mediterranean and leave precipitation before reaching the Taurus Mountains, which divide the Mediterranean coastal region of southern Turkey from the central Anatolian plateau. Therefore, the areas behind the mountains have a rain shadow character (Figure 5.3). When the HPC shifts south of the Caspian Sea, the pattern turns into southwesterly (SW) types, and the impact of the Genoa LPC can be seen in the region. Humidity is transferred throughout the western Mediterranean to the Marmara region without any geographic obstacles such as mountains. Every tenth of CT occurs in this type. The highest daily rainfall total applies to the D and E clusters. Average numbers of westerly types increase up to $13.69 \%$, and the contribution to winter rainfall is at its maximum in the western parts of the region. Similar synoptic conditions, like $\mathrm{N}$ cases, are shown during northwesterly (NW) patterns. Compared with $\mathrm{N}$ types, the NW patterns bring partly dry air from the Balkan countries, and, hence, lower daily precipitation values are recorded in the whole of Marmara. In cyclonic (C) types (the fifth most frequent CT), an LPC is located over Marmara, 
daily rainfall total increases to $7.18 \mathrm{~mm}$ and $9.34 \mathrm{~mm}$, and is the wettest CT for the D and E clusters, respectively. During anticyclonic (A) types, an HPC is located over Marmara and has the lowest daily rainfall potential of all sub-regions.
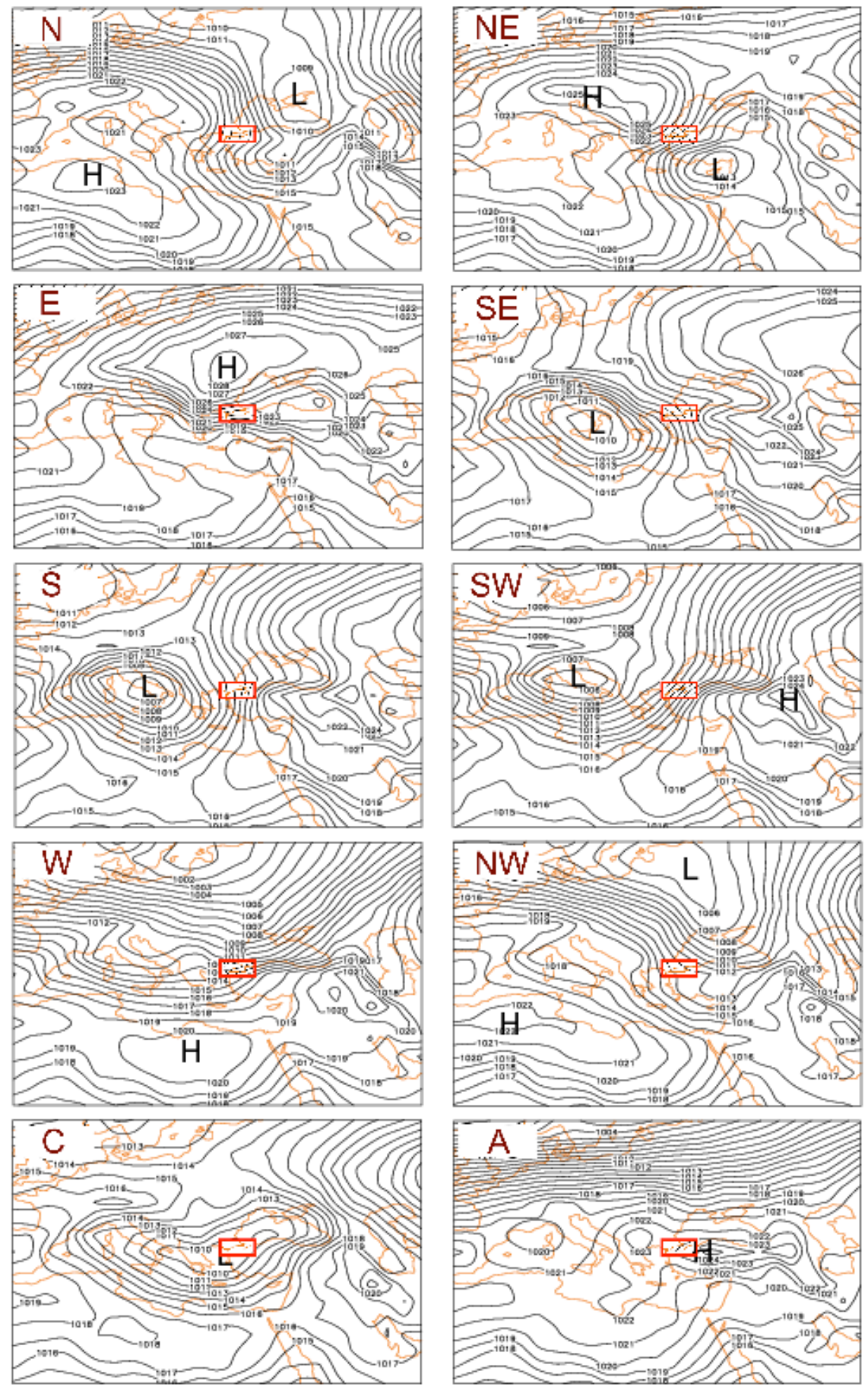

Figure 5.3 : Long-term wintertime daily mean sea level pressure (MSLP) composites of each of the eight main directional and two vorticity CTs during the period from 1960 to 2012. The red rectangle indicates the Marmara region. $\mathrm{H}$ and $\mathrm{L}$ mark the high and low pressure centres, respectively. 


\subsection{Precipitation Occurrence and Amount}

Precipitation occurrence of each $\mathrm{CT}$ is derived from the daily rainfall totals. A wet day is defined when the daily total precipitation is greater than or equal to $1 \mathrm{~mm}$. In the study, the probability of having a wet day for each CT and clusters was analyzed. As seen in Figure 4.4, the wettest days are shown as N, NE, NW, and C types. In terms of $\mathrm{N}$ patterns, the highest probability of having a wet day was observed in the north and northeast part of the region. The probability ratio decreases to $57 \%$ west and northwest of the Marmara region. In NE cases, the chance of having wet days is much more distinct between north-northeast and west-northwest areas of the region. In spite of the low frequencies of NW types, $70 \%$ of the patterns result in a wet day in clusters $\mathrm{A}, \mathrm{B}$, and $\mathrm{C}$. In cyclonic conditions, observed frequencies of wet days are almost $70 \%$ in the four clusters (except cluster B). Although N, NE, NW, and C types result in a high probability of rainy conditions in winter months, their frequencies $(22.5 \%$ in Table 5.2) and their contribution to total rainfall (average $43.5 \%$ in Table 5.2) cannot give enough detailed information to explain the rainfall characteristics of the region. Therefore, we explored the chances of rainfall occurrence and intensity during each $\mathrm{CT}$ and cluster by using two index calculations.

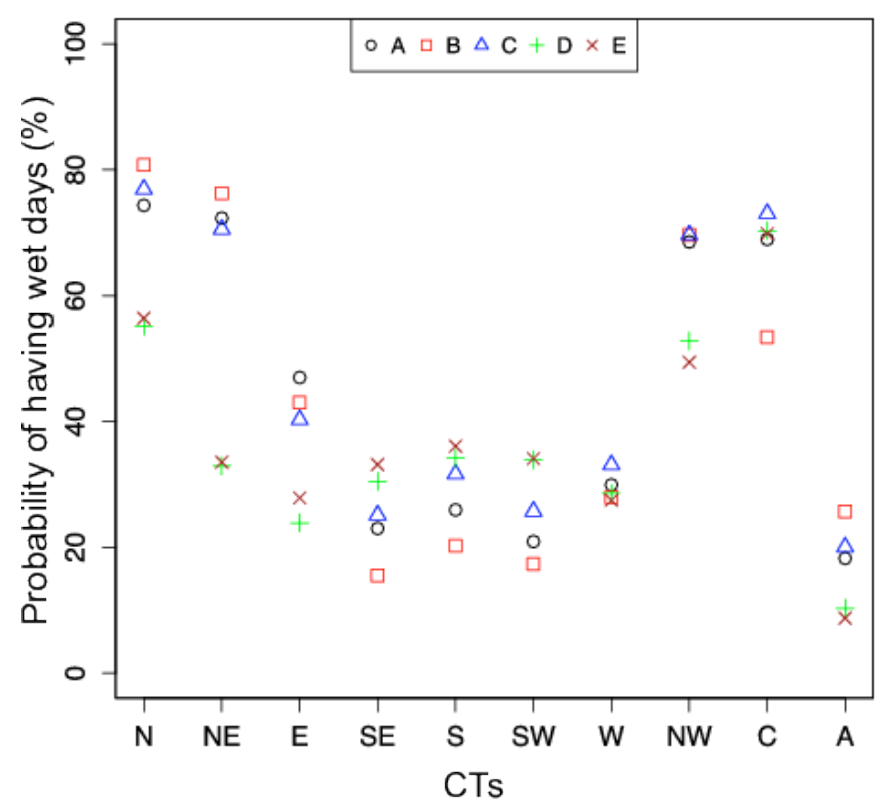

Figure 5.4 : The probability of having a wet day for the directional and two vorticity CTs for the five sub-basins (cluster letters A, B, C, D, and E). 


\subsection{Spatial Variability of Precipitation}

Two indices were defined and applied to the Iberian rainfall to determine the role of each CT in precipitation occurrence and amount (Goodess and Jones 2002). Brisson et al., (2011) also applied these indices to the limited number of stations to characterize different precipitation regions in Belgium. The first index was termed the normalized relative occurrence of rainy days (by the ratio $P R O B_{c t} / P R O B_{t o t}$ ) and the formula is as follows:

$$
\frac{P_{R O B}}{P R O B_{t o t}}=\frac{N_{w_{t} t_{c t}}}{N_{c t}} \cdot \frac{N_{t o t}}{N_{w_{\text {wet }}}},
$$

where $N_{\text {wet }_{c t}}$ and $N_{c t}$ are the total number of wet days $(>=1 \mathrm{~mm})$ and total number of days within the CT. $N_{\text {tot }}$ and $N_{\text {wet }}$ are as the total number of days and the total number of wet days within the entire period (53 years).

The second index was used to describe positive or negative anomalies based on the intensity of precipitation during $\mathrm{CT}$, which was termed normalized relative daily intensity of $\left(P R E C_{c t} / P R E C_{t o t}\right)$, and can be written as:

$$
\frac{\text { PREC }_{c t}}{\text { PREC }_{\text {tot }}}=\frac{T A R_{c t}}{N_{\text {wet }_{c t}}} \cdot \frac{N_{\text {wet }_{\text {ot }}}}{\text { TAR }_{\text {tot }}},
$$

where $T A R_{c t}$ is the total accumulation of rain during the wet days of a specific CT, $N_{\text {wet }_{c t}}$ is the total number of wet days within the CT, $N_{\text {wet }_{\text {tot }}}$ is the total number of wet days, and $T A R_{\text {tot }}$ is the total accumulation of rain during the wet days of the 53-year period.

If index values of $P R O B_{c t} / P R O B_{t o t}$ were higher (lower) than one, this implied a positive (negative) anomaly, which causes a high (low) chance of precipitation occurrence compared with the average of all CTs. An index $P R E C_{c t} / P R E C_{t o t}$ higher (lower) than one indicated that the intensity of rainfall on a wet day is larger (smaller) than the average intensity on a wet day during the entire period.

According to the results for the normalized relative occurrence of rainy days $\left(P R O B_{c t} / P_{R O B}{ }_{t o t}\right)$, wet $\mathrm{CTs}(\mathrm{N}, \mathrm{NE}, \mathrm{NW}$, and $\mathrm{C})$ indicate a high chance of precipitation in all sub-regions of the Marmara (Figure 5.5a). On the other hand, southerly components of the patterns (i.e. SE, S, and SW) have a high chance of rainy days appearing in the western parts of the region (clusters D and E). In 
addition, in E types, the high chance of wet days is more evident in the east of the region (clusters A and B) compared with the other clusters. The lowest precipitation occurrence of rainy days is shown during the A patterns in the whole of Marmara.

Based on the $P R E C_{c t} / P R E C_{t o t}$ results, the highest precipitation intensity gradients occur during the $\mathrm{N}$ and $\mathrm{C}$ types in the whole domain (Figure 5.5b). For NE cases, the high rainfall intensity of wet days is shown in the Marmara-Black Sea, Black Sea, and Marmara sub-basins (i.e. A, B, and C clusters) of the studied area. During NW types, high rainfall magnitude affects all Marmara except the stations close to the Black Sea (cluster B).

(a)

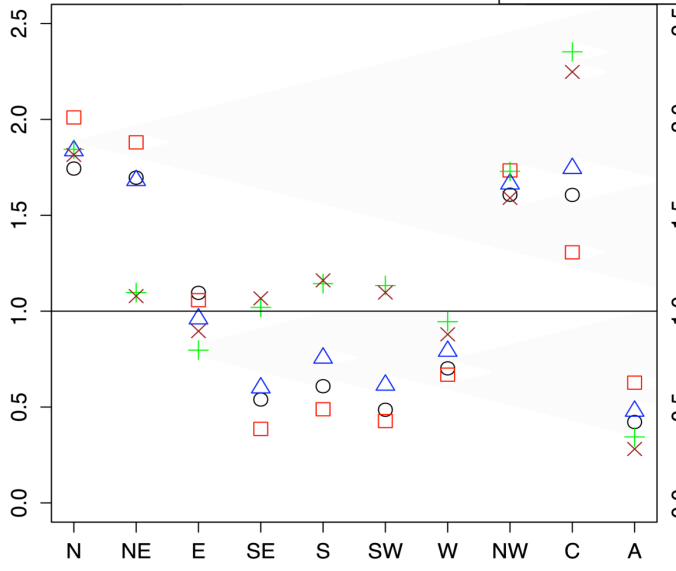

(b)

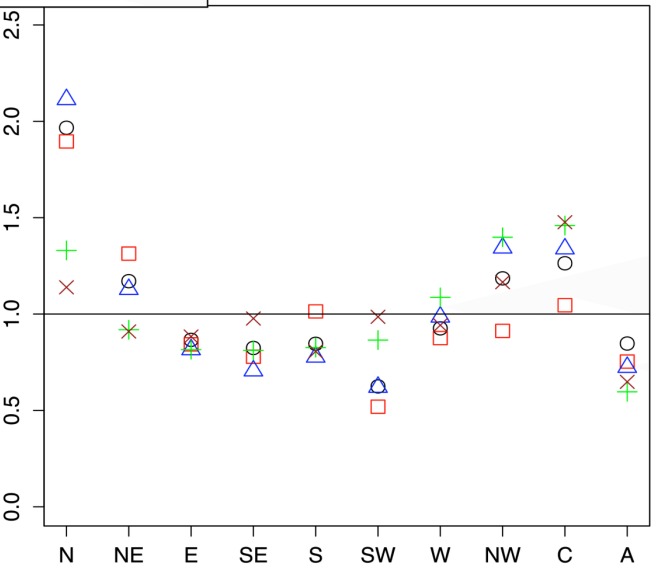

Figure 5.5 : a) The normalized relative occurrence of rainy days per CT $\left(\mathrm{PROB}_{\mathrm{ct}} / \mathrm{PROB}_{\mathrm{tot}}\right)$ and $\left.\mathbf{b}\right)$ the normalized relative daily intensity of precipitation per

$\mathrm{CT}\left(\mathrm{PREC}_{\mathrm{ct}} / \mathrm{PREC}_{\mathrm{tot}}\right)$ for each cluster and CT. Circle, square, triangle, plus, and multiplication signs mark the sub-regional precipitation marked by cluster letters $\mathrm{A}$, $\mathrm{B}, \mathrm{C}, \mathrm{D}$, and $\mathrm{E}$, respectively.

\subsection{Rainfall Magnitude Categories}

To explore the CTs that cause intense precipitation (see Section 5.4), we comprehensively analyzed the daily intensity of precipitation during particular CTs. For this reason, the classification of daily rainfall magnitude (PRCP) in previous works was adopted (Osborn et al., 2000; Osborn and Hulme 2002; Gallego et al., 2006). We constructed five categories of rainfall magnitude: no rain, light rain (0 $\mathrm{mm}<\mathrm{PRCP}<3 \mathrm{~mm})$, moderate rain $(3 \mathrm{~mm}<\mathrm{PRCP}<9 \mathrm{~mm})$, intense rain (9 $\mathrm{mm}<\mathrm{PRCP}<21 \mathrm{~mm})$ and very intense rain $(>21 \mathrm{~mm})$. Percentage contributions of $\mathrm{N}$ and C- CTs to the rainfall magnitude were analyzed for five clusters. As one can see 
from Figure 5.6a, every other day of the northerly types produced intense and very intense precipitation in the $\mathrm{A}, \mathrm{B}$, and $\mathrm{C}$ clusters. The distribution of the moderate and intense episodes was nearly the same in the B and C clusters. In the D and E, daily precipitation totals above $9 \mathrm{~mm}$ are evident in almost $22 \%$ and $26 \%$ of the all-N patterns. In terms of cyclonic conditions (Figure 5.6b), D and E sub-regions are more sensitive to the precipitation than the other three cluster zones. Very intense episodes are more common in the E sub-basins. Many flash floods occur during the activity of $\mathrm{C}$ types in this sub-basin. After transfer of more humidity and precipitation to the Aegean side of the region, the numbers of very intense episodes decrease in the Thrace basin. Because of the distance of the cyclone centre from the north and northeast of the region, the frequencies of the intense and very intense episodes decrease compared with the other basins.

(a)

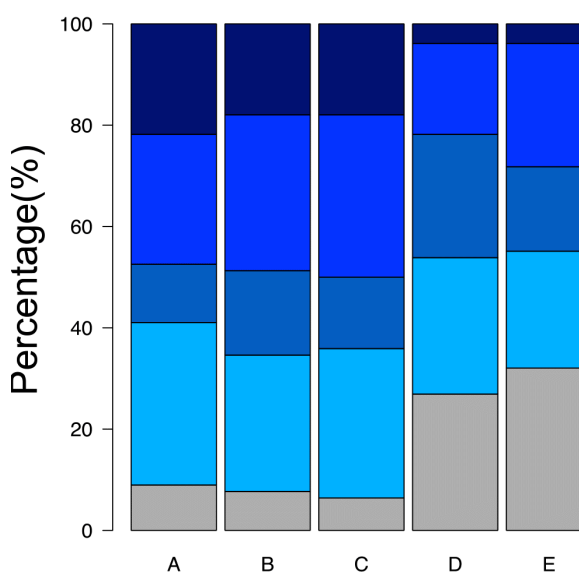

(b)

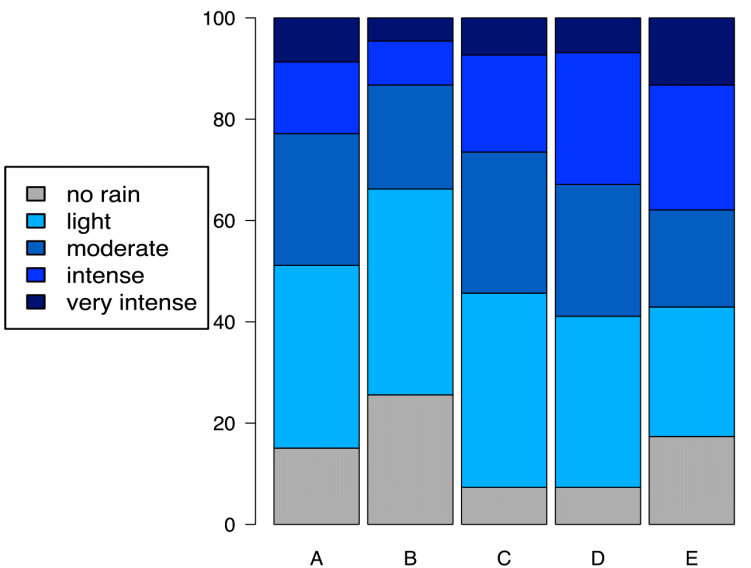

Figure 5.6 : Percentage contribution of a) $\mathrm{N}$ and b) $\mathrm{C}$ synoptic weather types to the winter categories of precipitation for five clusters. 


\section{CONCLUSIONS}

\subsection{Summary and Conclusions}

For the first time, the goal of this study is to improve our understanding of the precipitation characteristics and its spatial variability in Marmara Region, in relation with CTs and in response to the complex topography of the area. Therefore, we first classified the atmospheric circulation types (CTs) that influence Marmara Region (NW Turkey) by applying the automated Lamb Weather Type methodology on daily mean NCEP/NCAR reanalysis sea level pressure data. Then, we investigated the long term mean relationship between these CTs and the precipitation characteristics for Marmara Region for the period of 1971-2010.

In the second part, in addition to the temporal variation of CTs and trends in the occurrence frequencies of these CTs and how their precipitation potentials change in time, the linkage of the synoptic-scale variability and the large-scale modes of climate variability and regional climates of Marmara was clarified. For large-scale circulations, basic teleconnection patterns (TPs); (i.e. NAO, EAWR, AO, and SCA) index values were used for the period 1971-2012. Then, the relation with TPs and CTs and their influences on precipitation characteristics of the Marmara Region were investigated.

At the end, the influence of CTs on regional patterns of precipitation was studied for the region. For this purpose, Ward's method clustering technique was applied to the daily winter precipitation amounts. Later, two indices (i.e. normalized relative occurrence of rainy days $\left(P R O B_{c t} / P R O B_{t o t}\right)$ and normalized relative daily amount of precipitation $\left(P R E C_{c t} / P R E C_{t o t}\right)$ were applied to all cluster solutions to investigate the influence of CTs on the occurrence and intensity of precipitation.

\subsubsection{Atmospheric CTs and their influence on precipitation}

Based on the analysis of atmospheric CTs and their relationship with precipitation in the Marmara Region, the following conclusions can be highlighted: 
- Resulting ten main atmospheric CTs can be further classified - subjectively in three main groups, according to the configuration of their large scale MSLP anomaly distribution: Category I (NE, E), Category II (SW, S, SE) and Category III (W, NW, N). Cyclonic (C) and Anticyclonic (A) patterns are the remaining two of those ten CTs.

- Category I types (NE and E), featuring a centre of high pressure anomaly at Eastern Europe and a low in the Middle East are the most dominant throughout the year. They are followed by Category II (S, SW and SE), which are characterized by a low around Italy and do reach their highest frequency in Marmara Region during DJF.

- $\mathrm{C}$ and $\mathrm{N}$ (types associated with nearby cyclones and cold fronts respectively) have the most rainfall potential when regional averages are considered, both annually and during DJF. However, they are two of the least frequent observed, therefore their contribution to long-term totals are rather low. NE and $\mathrm{E}$ (Category I) are potentially the rainiest in the northeastern stations due to the local effects of the Black Sea through the sea-effect mechanism; while SW, SE and S (Category III) patterns have more rainfall potential than NE and $\mathrm{E}$ in western stations, as these are closer to the cyclonic activity in the greater Mediterranean area. Accordingly, there is a broad east-west contrast in the dominant rainfall modes; i.e. NE and $\mathrm{E}$ dominate the rainy days of the eastern and central Marmara; while S, SW and SE supply more precipitation to an area confined to the extreme west, especially during DJF.

\subsubsection{Temporal behavior of atmospheric CTs and their association with TPs}

Based on the temporal evolution of atmospheric CTs and their correlations with TPs, the following conclusions can be highlighted:

- Statistically significant increasing (decreasing) trends are shown in SW (NE) cases during DJF and SON. This implies that the influence of low pressure centre over Italy than high pressure centre over eastern Europe is more distinct. On the other hand, we cannot see similar trend properties with Cyclonic (C) types. This condition may be explained by shifting of cyclones to the south of Turkey or disappear without come to Marmara. 
- The relationship between teleconnection patterns and the frequencies of atmospheric CTs indicate that EAWR pattern has positive correlation with NE and NW in DJF. On the other hand, negative correlations are shown with SW and Cyclonic types. This explains that when the increasing trends are viewed in EAWR, monthly frequencies of NE and NW also increase or the frequencies of SW and C decrease. The leading role of AO on CTs is similar to that of EAWR, except NW in this season. In regard to NAO, it is shown clear negative significant correlation with $\mathrm{C}$ types.

- In SON, NAO and AO have negative significant correlations with SW and significant positive correlations with the Category I types (NE and E). EAWR has the only negative relation with SW in this second rainiest season.

- From the results, substantial daily rainfall amounts are measure during NE although the numbers of its decrease in DJF. When investigated this condition, it is shown that the region is mainly influenced the seesaw of low and high pressure centres over Cyprus (or central Anatolia) and eastern Europe. In addition to these synoptic conditions, rising of sea surface temperatures (SSTs) over Black Sea (0.6 C higher than the long term means) conclude with more precipitation intensities due to the transferring of more moisture to the Marmara.

\subsubsection{Influence of CTs on regional patterns of precipitation}

Based on the role of CTs on the regional patterns of the Marmara precipitation, the following conclusions can be highlighted:

- Firstly, Ward's method clustering techniques was applied to the daily winter precipitation amounts. Then, we extracted the long-term composites and frequencies of atmospheric CTs and explored their contribution to daily precipitation intensity for each cluster. Later, two indices (i.e. normalized relative occurrence of rainy days $\left(P R O B_{c t} / P R O B_{t o t}\right)$ and normalized relative daily amount of precipitation $\left(P R E C_{c t} / P R E C_{t o t}\right)$ were applied to all cluster solutions to investigate the influence of CTs on the occurrence and intensity of precipitation. 
- As a consequence of the Ward's method, the region was divided into five main sub-regional precipitation climates: Marmara-Black Sea, Black Sea, Marmara, Thrace, and Aegean (cluster letters A, B, C, D, and E, respectively). According to the CTs results, N, NE, NW and cyclonic (C) patterns have the highest probability that rainfall will occur in the whole Marmara Region. These types were also defined as the wet CTs by Baltaci et al., (2015). Additionally, $P R O B_{c t} / P R O B_{\text {tot }}$ results indicate that whereas the eastern part of the region concludes with precipitation during $\mathrm{E}$ days, western basins have rainy days during the southerly components of the patterns ( $\mathrm{S}$, SE, and SW).

- By analyzing the distribution of average precipitation intensity for each CT, it was found that the highest probability of extreme precipitation is during $\mathrm{N}$ and cyclonic CTs in all cluster zones. As explained by Baltacı et al., (2015), type $\mathrm{N}$ divides the region into two parts (as east and west) with regard to precipitation intensity, and the eastern stations become remarkably wetter than others. However, the precipitation intensity index showed that west subregions (clusters D and E) also have the highest precipitation intensity gradients during $\mathrm{N}$ cases. This can be explained by intense moisture transport from the Marmara Sea. On the other hand, we found that the highest daily rainfall totals occur in the $\mathrm{N}, \mathrm{NW}$, and cyclonic (C) types in clusters $\mathrm{D}$ and E. During C types, almost $37 \%$ of the daily precipitation intensities are greater than $9 \mathrm{~mm} /$ day in these clusters, which make affected sub-regions more sensitive to the flash flood events. Concerning eastern clusters, although the influence of NE type on rainfall magnitude is more significant, NW patterns show high precipitation intensities in all clusters of the region, except the Black Sea.

Marmara Region is an area of transition between summer-dry Mediterranean and year-round wet, oceanic Black Sea climate zones. In a similar fashion, the impact of weather types on precipitation appears to alter as one goes from the more Mediterranean-influenced southwest to the Black Sea controlled zone of northeast According to the results, the relationship between large-scale circulation and the precipitation climate of this region is nor-t spatially uniform. Thus, anticipated 
changes in future large-scale atmospheric circulation on the region cannot be expected to have similar effects over the precipitation climate of the entire area; which should definitely be a point of consideration in determining the water management policies. 


\section{REFERENCES}

Arraut, J.M. \& Nobre, C. (2012). Aerial Rivers and Lakes: Looking at the largescale moisture transport and its relation to Amazonia and subtropical rainfall in South America, Journal of Climate, 25, 543-556.

Baltacı, H., Göktürk, O.M., Kındap, T., Ünal, A. \& Karaca, M. (2015). Atmospheric circulation types in Marmara Region (NW Turkey) and their influence on precipitation, International Journal of Climatology, $35,1810-1820$.

Barnston, A.G. \& Livezey, R.E. (1987). Classification, seasonality and persistence of low-frequency atmospheric circulation patterns, Monthly Weather Review, 115, 1083-1126.

Belkin, I.M. (2009). Rapid warming of Large Marine Ecosystems, Progress in Oceanography, 81, 207-213.

Bice, D., Montanari, A., Vucetic, V. \& Vucetic, M. (2012). The influence of regional and global climatic oscillations on Croatian climate, International Journal of Climatology, 32, 1537-1557.

Blair, D. (1998). The Kirchhofer technique of synoptic typing revisited, International Journal of Climatology, 18, 1625-1635.

Bozkurt, D. \& Şen, O. L. (2011). Precipitation in the Anatolian Peninsula: sensivity to increased SSTs in the surrounding seas, Climate Dynamics, 36, 711-726.

Brisson, E., Demuzere, M., Kwakernaak, B. \& Van Lipzig, N.P.M. (2011). Relations between atmospheric circulation and precipitation in Belgium, Meteorology and Atmospheric Physics, 111, 27-39.

Burt, T.P. \& Ferranti, E.J.S. (2012). Changing patterns of heavy rainfall in upland areas: a case study from northern England, International Journal of Climatology, 32, 518-532.

Collier, G.C. \& Krzysztofowicz, R. (2000). Special issue on quantitative precipitation forecast, Journal of Hydrology, 239, 1-338.

Cullen, H.M. \& DeMenocol, P.B. (2000). North Atlantic influence on TigrisEuphrates streamfow, International Journal of Climatology, 20, 853863.

Dayan, U., Tubi, A. \& Levy, L. (2012). On the importance of synoptic classification methods with respect to environmental phenomena, International Journal of Climatology, 32, 681-694.

Demuzere, M., Werner, M., van Lipzig, N.P.M. \& Roeckner, E. (2009). An analysis of present and future ECHAM5 pressure fields using a classification of circulation patterns, International Journal of Climatology, 29, 1796-1810. 
Dittmann, E., Barth, S., Lang, J. \& Müller-Westermeier, G. (1995). Objektive Wetterlagenklassifikation (Objective Weather Type Classification), Berichte des Deutschen Wetterdienstes,197, Offenbach a. M., Germany (in German).

Dünkeloh, A. \& Jacobeit, J. (2003). Circulation of dynamics of Mediterranean precipitation variability, International Journal of Climatology, 23, $1843-1866$.

Erinç, S., (1962). Climatology and Its Methods (in Turkish) Alfa Basım ve Dağıtım : Istanbul, Turkey.

Erinç, S. \& Sungur, K.A. (1962). Monthly sequence and frequencies of weather types in Istanbul, Rev. Geogr. Inst. Univ. Ist.,9-10, 83-107.

Erinç, S. (1984). Climatology and its methods. Güray Press Inc: Istanbul.

Ezber, Y., Sen, O.L., Kindap, T. \& Karaca, M. (2007). Climatic effects of urbanization in Istanbul: a statistical and modeling analysis, International Journal of Climatology, 27, 667-679.

Ferranti, L. \& Viterbo, P. (2006). The European summer of 2003:sensivity to soil water initial conditions, Journal of Climate, 19, 3659-3680.

Fovell, R.G. \& Fovell, M.C. (1993). Climate zones of the conterminous United States defined using cluster analysis, Journal of Climate, 6, 21032135.

Gallego, M.C., Garcia, J.A., Vaquero, J.M. \& Mateos, V.L. (2006). Changes in frequency and intensity of daily precipitation over the Iberian Peninsula, Journal of Geophysical Research, 111, D24105.

Garcia-Serrano, J., Polo, I., Rodriguez-Fonseca, B. \& Losada, T. (2013). Largescale atmospheric response to eastern Mediterranean summer-autumn SST anomalies and the associated regional impact, Climate Dynamics, $41,2251-2265$.

Goktürk, O.M., Fleitmann, D., Badertscher, S., Cheng, H., Edwards, R.L., Leuenberger, M., Fankhauser, A., Tuysuz, O. \& Kramers, J. (2011). Cliamte on the southern Black Sea coast during the Holocene: implications from the Sofular Cave record, Quaternary Science Reviews, 30, 2433-2445.

Gong, X. \& Richman, M.B. (1995). On the application of cluster analysis to growing season precipitation data in North America east of the Rockies, Journal of Climate, 8, 897-931.

Goodess, C.M. \& Jones, P.D. (2002). Links between circulation and changes in the characteristics of Iberian Rainfall, International Journal of Climatology, 22, 1593-1615.

Goodess, C.M. \& Palutikof, J.P. (1998). Development of daily rainfall scenarios for southeast Spain using a circulation-type approach to downscaling, International Journal of Climatology, 18, 1051-1083.

Goossens, C. \& Berger, A. (1986). Annual and seasonal climatic variations over the Northern Hemisphere and Europe during the last century, Annales Geophysicae, 4, 385-399. 
Gouveia, C., Trigo, R.M., DaCamara, C.C., Libonati, R. \& Pereira, J.M.C. (2008). The North Atlantic Oscillation and European vegetation dynamics, International Journal of Climatology, 28, 1835-1847.

Hess, P. \& Brezowsky, H. (1952). Katalog der Großwetterlagen Europas (Catalog of the European Large Scale Weather Types), Berichte des Deutschen Wetterdienstes in der US-Zone 33, Bad Kissingen, Germany (in German).

Holroyd, E.W. (1971). Lake-effect cloud bands as seen from weather satellites, Journal of the Atmospheric Sciences, 28, 1165-1170.

Hurrell, J.W., Kushnir, Y., Ottersen, G. \& Visbeck, M. (2003). An overview of the North Atlantic Oscillation, Geophysical Monograph, 134, 2003.

Huth, R. (1993). An example of using obliquely rotated principal components to detect circulation types over Europe, Meteorologische Zeitschrift, 2, 285-293.

Huth, R., Beck C., Philipp A., Demuzere, M., Ustrnul, Z., Cahynova, M., Kysely, J. \& Tveito, O.E. (2008). Classifications of atmospheric circulation patterns, Annals of the New York Academy of Sciences, 1146, 105152.

Iglesias, A. \& Quiroga, S. (2007). Measuring the risk of climate variability to cereal production at five sites in Spain, Climate Research, 34, 45-57.

Iyigun, C., Türkeş, M., Batmaz, İ., Yozgatligil, C., Purutçuoğlu, V., Koç, E.K. \& Öztürk, M.Z. (2013). Clustering current climate regions of Turkey by using a multivariate statistical method, Theoretical and Applied Climatology, 114, 95-106.

Jenkinson, A.F. \& Collison, F.P (1977). An initial climatology of gales over the North Sea, Synoptic Climatology Branch Memorandum 62, Meteorological Office, Bracknell, UK.

Jones, P.D., Hulme, M. \& Briffa, K.R. (1993). A comparison of Lamb circulation types with an objective classification scheme, International Journal of Climatology, 13, 655-663.

Kalnay, E., Kanamitsu, M., Kistler, R., Collins, W., Deaven, D., Gandin, L., Iredell, M., Saha, S., White, G., Wollen, J., Zhu, Y., Chelliah, M., Ebisuzaki, W., Higgins, W., Janowiak, J., Mo, K.C., Ropelewski, C., Wang, J., Leetmaa, A., Reynolds, R., Jenne, R. \& Joseph, D. (1996). The NCEP/NCAR 40 year reanalysis project, Bulletin of the American Meteorological Society, 77, 437-471.

Karaca, M., Tayanç, M. \& Toros, H. (1995). The effects of urbanization on climate of Istanbul and Ankara, Atmospheric Environment Part B-Urban Atmosphere, 29(23), 3411-3421.

Kindap, T. (2010). A severe sea-effect snow episode over the city of Istanbul, Natural Hazards, 54, 707-723.

Kömüşçü, A.Ü. \& Çelik, S. (2013). Analysis of the Marmara flood in Turkey, 7-10 September 2009: an assessment from hydrometeorological perspective, Natural Hazards, 66(2), 781-808. 
Krichak, S.O. \& Alpert, P. (2005). Signatures of the NAO in the atmospheric circulation during wet winter months over the Mediterranean region, Theoretical and Applied Climatology, 82, 27-39.

Krichak, S.O., Kishcha, P. \& Alpert, P. (2002). Decadal trends of main Eurasian oscillations and the Eastern Mediterranean precipitation, Theoretical and Applied Climatology, 72, 209-220.

Kutiel, H., Maheras, P., Türkeş, M. \& Paz, S. (2002). North Sea - Caspian Pattern (NCP) an upper level atmospheric teleconnection affecting the eastern Mediterranean: implications on the regional climate, Theoretical and Applied Climatology, 72, 173-192.

Lamb, H.H. (1972). British Isles weather types and a register of daily sequence of circulation patterns, 1861-1971, Geophysical Memoir 116, HMSO, London.

Linderson, M.L. (2001). Objective classification of atmospheric circulation over southern Scandinavia, International Journal of Climatology, 21, 155169.

Litynski, J. (1969). A numerical classification of circulation patterns and weather types in Poland, Prace PIHM, 97, 3-15 (in Polish).

Lopez-Bustins, J., Martin-Vide, J. \& Sanchez-Lorenzo, A. (2008). Iberia winter rainfall trends based upon changes in teleconnection and circulation patterns, Global and Planetary Change, 63, 171-176.

Lorenzo, M.N., Taboada, J.J. \& Gimeno, L. (2008). Links between circulation weather types and teleconnection patterns and their influence on precipitation patterns in Galicia (NW Spain), International Journal of Climatology, 28, 1493-1505.

Maheras, P., Xoplaki, E., Davies, T., Martin-Vide, J., Bariendos, M. \& Alcoforado, M.J. (1999) Warm and cold monthly anomalies across the Mediterranean basin and their relationship with circulation; 1860 1990, International Journal of Climatology, 19, 1697-1715.

Maktav, D., \& Erberk, F.S. (2005). Analysis of urban growth using multi-temporal satellite data in Istanbul, Turkey, International Journal of Remote Sensing, 26(4), 797-810.

Mo, K.C. \& Higgins, R.W. (1996). Large-scale moisture transport as evaluated in the NCEP/NCAR and the NASA/DAO Reanalyses, Journal of Climate, 9(7), 1531-1545.

Munoz-Diaz, D. \& Rodrigo, F.S. (2003). Effects of the North Atlantic Oscillation on the probability for climatic categories of local monthly rainfall in southern Spain, International Journal of Climatology, 23, 381-397.

Ning, L. \& Bradley, R.S. (2015). Winter precipitation variability and corresponding teleconnections over the northeastern United States, Journal of Geophysical Research: Atmospheres, 113, 7931-7945.

Niziol, T.A. (1987). Operational forecasting of lake effect snowfall in western and central New York, Weather and Forecasting, 2, 310-321. 
Oguz, T. (2005). Black Sea ecosystem response to climatic variations, Oceanography, 18(2), 122-133.

Oguz, T., Dippner, J.W. \& Kaymaz, Z. (2006). Climatic regulation of the Black Sea hydro-meteorological and ecological properties at interannual-todecadel time scales, Journal of Marine systems, 60, 235-254.

Osborn, T.J. \& Hulme, M. (2002). Evidence for trends in heavy rainfall events over the UK, Philosophical Transactions of the Royal Society A, 360, $1313-1325$.

Osborn, T.J., Hulme, M., Jones, P.D. \& Basnett, T.A. (2000). Observed trends in the daily intensity of United Kingdom precipitation, International Journal of Climatology, 20, 347-364.

Panagiotopoulos, F., Shahgedanova, M., Hannachi, A. \& Stephenson, D.B. (2005). Observed trends and teleconnections of the Siberian high: a recently declining center of action, Journal of Climate, 18, 14111422.

Partal, T. \& Kahya, E. (2006). Trend analysis in Turkish precipitation data, Hydrological Processes, 20, 2011-2026.

Philipp, A., Della-Marta, P.M., Jacobeit, J., Fereday, D.R., Jones, P.D., Moberg, A. \& Wanner, H. (2007). Long term variability of daily North Atlantic-European pressure patterns since 1850 classified by simulated annealing clustering, Journal of Climate, 20, 4065-4095.

Philipp, A., Bartholy, J., Beck, C., Erpicum, M., Esteban, P., Fettweis, X., Huth, R., James, P., Jourdain, S., Kreienkamp, F., Krennert, T., Lykoudis, S., Michalides, S.C., Pianko-Kluczynska, K., Post, P., Rasilla Alvarez, D., Schiermann, R., Spekat, A. \& Tymvios, F.S. (2010). Cost733cat-A database of weather and circulation type classifications, Physics and Chemistry of the Earth, 35, 360-373.

R Core Team (2013). $R$ : A language and environment for statistical computing. $R$ Foundation for Statistical Computing: Vienna. Retrieved from http://www.R-project.org/ (accessed 1 April 2014).

Reynolds, R.W., Smith, T.M., Liu, C., Chelton, D.B., Casey, K.S. \& Schlax, M.G. (2007). Daily high-resolution-blended analyses for sea surface temperature, Journal of Climate, 20, 5473-5496.

Rodriguez-Puebla, C., Encinas, A.H. \& Saenz, J. (2001). Winter precipitation over the Iberian peninsula and its relationship to circulation indices, Hydrology and Earth System Sciences, 5(2), 233-244.

Sahin, S. \& Cigizoglu, H.K. (2012). The sub-climate regions and the subprecipitation regime regions in Turkey, Journal of Hydrology, 450$451,180-189$.

Simmonds, I., Bi, D. \& Hope, P. (1999). Atmospheric water vapor flux and its association with rainfall over China in Summer, Journal of Climate 12(5), 1353-1367.

Soares, W.R. \& Marengo, J.A. (2009). Assessments of moisture fluxes east of the Andes in South America in a global warming scenario, International Journal of Climatology, 29 (10), 1395-1414. 
Sönmez, İ. \& Kömüşcü, A.ய̈. (2011). Reclassification of rainfall regions of Turkey by K-means methodology and their temporal variability in relation to North Atlantic Oscillation (NAO), Theoretical and Applied Climatology, 106, 499-510.

Steenburgh, W.J., Halvorson, S.F. \& Onton, D.J. (2000). Climatology of lakeeffect snowstorms of the Great Salt Lake, Monthly Weather Review, $128,709-727$.

Tayanç, M., Karaca, M. \& Yenigün, O. (1997). Annual and seasonal air temperature trends patterns of climate change and urbanization effects in relation with air pollutants in Turkey, Journal of Geophysical Research, 102(D2), 1909-1919.

The NCAR Command Language (NCL) (2014). UCAR/NCAR/CISL/VETS (Version 6.2.0) [Software]. NCAR: Boulder, CO, doi: 10.5065/D6WD3XH5.

Toros, H. (2012). Spatio-temporal precipitation change assessments over Turkey, International Journal of Climatology, 32, 1310-1325.

Trenberth, K.E., Jones, P.D., Ambenje, P., Bojariu, R., Easterling, D., Tank, A.K., Parker, D., Rahimzadeh, F., Renwick, J.A., Rusticucci, M., Soden, B. \& Zhai, P. (2007). Observations: surface and atmospheric climate change. In: Solomon S, Qin D, Manning M, Chen Z, Marquis M, Averyt KB, Tignor M, Miller HL. (Eds.), Climate Change 2007: The Physical Science Basis. Contribution of Working Group I to the Fourth Assessment Report of the Intergovernmental Panel on Climate Change. Cambridge University Press, Cambridge, United Kingdom, New York, NY, USA, pp. 235-336.

Trigo, I.F., Bigg, G.R. \& Davies, T.D. (2002). Climatology of cyclogenesis mechanisms in the Mediterranean, Monthly Weather Review, 130, 549-569.

Trigo, R.M. \& DaCamara, C.C. (2000). Circulation weather types and their influence on the precipitation regime in Portugal, International Journal of Climatology, 20, 1559-1581.

Trigo, I.F., Davies, T.D. \& Bigg, G.R. (1999). Objective climatology of cyclones in the Mediterranean region, Journal of Climate, 12, 1685-1696.

Trigo, R.M., Pozo-Vazquez, D., Osborn, T.J., Castro-Diez, Y., Gamiz-Fortis, S. \& Esteban-Parra, M.J. (2004). North Atlantic Oscillation influence on precipitation, river flow and water resources in the Iberian Peninsula, International Journal of Climatology, 24, 925-944.

Turuncoglu, U.U. (2015). Identifying the sensivity of precipitation of Anatolian peninsula to Mediterranean and Black Sea surface temperature, Climate Dynamics, 44, 1993-2015.

Türkeş, M. (1996). Spatial and temporal analysis of annual rainfall variations in Turkey, International Journal of Climatology, 16, 1057-1076. 
Türkeş, M. \& Erlat, E. (2003). Precipitation changes and variability in Turkey linked to the North Atlantic Oscillation during the period 1930-2000, International Journal of Climatology, 23, 1771-1796.

Türkeş, M. \& Erlat, E. (2005). Climatological responses of winter precipitation in Turkey to variability of the North Atlantic Oscillation during the period 1930-2001, Theoretical and Applied Climatology, 81, 45-69.

Türkeş, M. \& Tatl, H. (2011). Use of the spectral clustering to determine coherent precipitation regions in Turkey for the period 1929-2007, International Journal of Climatology, 31, 2055-2067.

Turkish Institute of Statistics (TIS) (2011). The results of the address-based census. Retrieved from http://www.tuik.gov.tr/PreTablo.do?alt_id=39 (accessed 23 January 2014).

Url-1 < http://www.cpc.ncep.noaa.gov/data/telecontents.shtml>. Retrieved November 5, 2014.

Url-2 < http://www.esrl.noaa.gov/psd >. Retrieved September 12, 2013.

Ünal, Y., Kındap, T. \& Karaca, M. (2003). Redefining the climate zones of Turkey using cluster analysis, International Journal of Climatology, 23, $1045-1055$.

Ünal, Y.S., Deniz, A., Toros, H. \& İncecik, S. (2012). Temporal and spatial patterns of precipitation variability for annual, wet, and dry seasons in Turkey, International Journal of Climatology, 32, 392-405.

Walker, G.T. (1924). Correlation in seasonal variation of weather, Memoirs of India Meterological Department, IX, 25, 275-332.

Xoplaki, E. (2002). Climate variability over the Mediterranean. Phd. Thesis. University of Bern, Switzerland.

Ziv, B., Saaroni, H. \& Alpert, P. (2004). The factors governing the summer regime of the eastern Mediterranean, International Journal of Climatology, 24, 1859-1871. 


\section{CIRRICULUM VITAE}

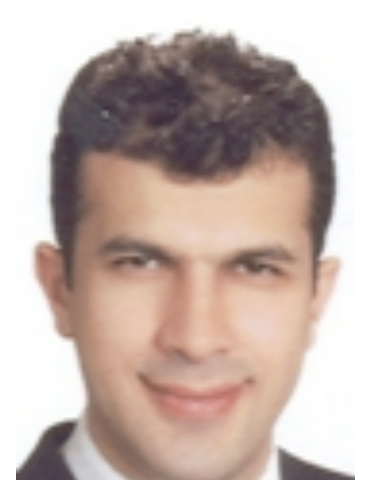

Name Surname: Hakkı BALTACI

Place and Date of Birth: Kırşehir, 20.01.1980

Address: Fetih mah. Hicazkar sok. Bagkur Sitesi 10A Blok D:23 34704 Cevizli-

Kartal/Istanbul

E-mail: baltacihakki@gmail.com

B.Sc.: ITU, Meteorology Engineering (1998-2004)

M.Sc.: ITU, Eurasia Institute of Earth Sciences, Earth System Science (2004-2010)

PhD: ITU, Eurasia Institute of Earth Sciences, Earth System Science (2011-2015)

Professional Experience and Rewards: Meteorologist at Turkish State

Meteorology Service (1998-...,.)

\section{Publications:}

\section{SCI-indexed papers:}

- Baltacı, H., Göktürk, O.M., Kındap, T., Ünal, A., Karaca, M., 2015. Atmospheric circulation types in Marmara Region (NW Turkey) and their influence on precipitation, International Journal of Climatology, 35, 1810-1820.

- Baltacı, H., Kındap, T., Ünal, A., Karaca, M., 2015. The influence of atmospheric circulation types on regional patterns of precipitation in Marmara (NW Turkey), Theoretical and Applied Climatology, DOI 10.1007/s00704-0151653-1, in press.

\section{Peer reviewed proceedings:}

- Baltaci, H., Sen, O.L., Karaca, M., 2010. Investigating of the relationship between landslide and precipitation and the assessment of minimum threshold values for eastern Black Sea Region (Rize, Trabzon, Giresun), 1st International Meteorology Semposium, Ankara. 54-66. 
- Baltaci, H., Kindap, T., Unal, A., Göktürk, O.M., Baltacibasi, S., Pozzoli, L., Incecik, S., Karaca, M., 2012. The effects of synoptic circulation types on PM10 concentrations in the Northwestern of Turkey, Air Quality Management at Urban, Regional and Global Scales, 4th International Symposium and IUAPPA Regional Conference, Istanbul.

- Baltaci, H., Göktürk, O.M., Kindap, T., Unal, A., Karaca, M., 2013. Synoptic weather patterns and their relation on precipitation in the Marmara Region, 3rd Turkey Climate Change Congress, Istanbul.

- Baltaci, H., Kindap, T., Chun, K.P., Yetemen, Ö., Unal, A., Tayanç, M., Karaca, M., 2015. Trends in climate extremes in the Marmara Region (NW Turkey) and their connection to the atmospheric circulation types, 7th Atmospheric Science Symposium, Istanbul. Vol. 2, pp. 744-758.

\section{Conference Papaers, Posters and Presentations:}

- Baltaci, H. 2011. Radiosonde observations of gravity waves in the lower atmosphere over Istanbul, Organization Scientifique et Technique Internationale Du Vol A Voile, Antalya.

- Baltaci, H., Kindap, T., Unal, A., Karaca, M. 2012. Analysis of synoptic weather types and its influence on precipitation on Marmara Region (NW Turkey), Geophysical Research Abstracts, Vol. 14, EGU2012-4171-1.

- Baltaci, H., Kindap, T., Unal, A., Karaca, M. 2014. Detection of overshotingcloud tops (OTs) and their relationship to severe weather over Europe, Organization Scientifique et Technique Internationale Du Vol A Voile, Lezsno-Poland.

- Baltaci, H., Kindap, T., Unal, A., Karaca, M. 2015. Detection of volcanic ash using multispectral satellite data, Organization Scientifique et Technique Internationale Du Vol A Voile, Winterthur-Switzerland. 